\title{
Living in Freedom among the Infidels in Times of Conflict, 1492-1767
}

Aside from exiles who had fled North Africa for political reasons, many other Muslims were able to reach the Iberian Peninsula, or Italy and the nearby islands, without too much difficulty. These were merchants and sailors who, contrary to all expectations, appear in Spanish ports in spite of the official state of hostility between their countries and the Hispanic monarchy. Some came intending to convert to Christianity, while others were more transient travelers or adventurers.

Hundreds of Muslims remained for long periods, or permanently, on Spanish territory for a variety of reasons. It is important to stress that the permanent residents might or might not become Christian. Those who did might have converted before crossing to Spain - a choice that usually, but not always, made their entry easier - or might have done so once on Spanish soil. For some there might have been a spiritual motive, but many were fleeing hunger or punishment for crimes committed in their native lands. Many adventurers, too, decided to travel to the Peninsula either temporarily or permanently. Some Moriscos managed to return to Spain after their expulsion, either for the rest of their lives or until they were expelled again. All these groups together add up to considerable numbers. Their flow was never interrupted during the period of our study, which was characterized by an official state of conflict between the Hispanic monarchy on one side and the Sultan of Morocco, the Dey of Algiers, the Beys of Tunis and Tripoli, and the Caliph in Constantinople on the other.

\subsection{Maghrebi, Ottoman, and Persian Ambassadors}

We have already observed that studies on Spain's relations with Muslim countries in the Early Modern age usually emphasize the chronic hostility between the two parties throughout that period; but in fact those relations were not always adversarial. The Spanish monarchy and some North African kingdoms wove ties that ranged from alliances against a common enemy to lord-andvassal relationships. ${ }^{1}$ These arrangements were the most prominent feature of

1 See the interesting study by Boubaker, "Le traité hispano-hafside," and by the same author "L'Empéreur Charles Quint et le sultan hafside." 
Spanish policy in the central and eastern Maghreb until the definitive Ottoman conquest of Tunis in 1574. Even after that date there were alliances with some local kingdoms, such as that of Kuku, that resisted being swallowed up by the powerful Deys of Algiers. The policy of allying with the sultans of Morocco was clear even when it was not the subject of formal agreements. There were even truces with the Ottoman Empire, with which Spain had almost no armed clashes in the seventeenth and eighteenth centuries. We have solid studies on negotiations between the Spanish monarchy and North African and Levantine rulers, but most of them focus on the activities of Spanish envoys and ambassadors in North Africa. ${ }^{2}$

In this section we shall be concerned chiefly with the frequent arrival on Spanish soil of ambassadors and envoys from the Empire of Morocco, the Regencies of Algiers, Tunis, and Tripoli, the Ottoman Empire, and faraway Safavid Persia. Our research, which should be considered a first step, reveals a much larger number than has been identified until now, and future studies will undoubtedly find even more.

From the late fifteenth century to the middle of the seventeenth, many embassies arrived from Tunis and Algiers; from about 1500 to 1550 the chief ports of arrival were those of the Crown of Aragon, that is, Majorca, Valencia, and above all Barcelona. In 1493 Ferdinand the Catholic approved the expenditures for Ciricassi, the ambassador from Bougie, and his five companions during their stay in Barcelona:

Six Barcelona libras and twelve sólidos for the rental of their house, with bedding for six beds that were rented as accomodation for Ciricassi, ambassador from the King of Bougie, and his retinue, in which they resided for one month and three days. ${ }^{3}$

In the same year Ferdinand gave a safe-conduct for two months to Raeç Cacym, "a Moor from Bougie," so that he could come to the Spanish court:

2 Escribano Páez, "Los actores de la diplomacia" and "Negotiating with the Infidel"; Hernández Sau, "Gifts across the Mediterranean Sea" and "De la infidelidad a la amistad"; Bunes Ibarra, "Entre la paz y la guerra."

3 "Seis libras y doce sólidos barceloneses por razón del loguero de su casa, con seis camas de ropa, que ha logado por possada para Ciricassi, embaxador del Rey de Bugía, y de sus servidores, en la qual ha stado por tiempo de hun mes y tres días": Ferdinand the Catholic, Barcelona, 3 September 1493, in Torre, Documentos sobre las relaciones, 4:293. 
You may come in safety with two of your servants, by sea and by land, from our own kingdoms and territories or from any others, with the clothing, money, and effects that you may bring with you, coming to our court, staying and [then] returning to Bougie, and no one may seize, detain, disturb, or hold you in your person or your goods. ${ }^{4}$

In June of that year a safe-conduct was given to Abrahim Cerquan, a Moor who came from Tunis on royal business:

Because the Moor Abrahim Cerquan, our subject and vassal, has come from the city of Tunis for matters that pertain to our service, and to negotiate certain things, he must travel and act in our kingdoms and lands, and our wish is that he be well treated and not be disturbed in any way ... .We ensure the said Ibrahim Cerquam, with all his coin, gold, silver, jewels, clothing, and other effects he may bring with him. ${ }^{5}$

In September 1494 a safe-conduct was issued to an ambassador from the king of Tunis:

To Don Cach, a Moor, ambassador from the illustrious king of Tunis, sent to us: that in any city or seaport of our kingdoms and territories, as he thinks best, with seven or eight Moors whose names we record expressly here, may go to Barbary with any vessel or ship owned by Christians, with all their clothing, money, goods, and merchandise. ${ }^{6}$

4 "[Para que] podays venir seguro, con dos criados vuestros, por la mar y por la tierra, assi de nuestros reynos y señoríos como de otros cualesquiere, con vuestras ropas, dineros y cosas, que con vos truxierdes, viniendo a nuestra corte, stando y tornando en Bugia, sin que nadie vos pueda prender, detener, molestar, ni embargar en persona ni en bienes": Ferdinand the Catholic, Barcelona, 20 June 1493, in Torre, Documentos, 4:226.

5 "Por quanto Abrahim Cerquan, moro, subdito y vasallo nuestro, es venido de la ciudat de Tunis por cosas que cumplen a nuestro servicio, e por negociar algunas cosas ha de andar e de practicar en nuestros reynos y tierras, e la voluntat nuestra es que sea bien tratado, e no sea en cosa alguna molestado ... asseguramos el dicho Ibrahim Cerquam, con todos sus dineros, oro, plata, joyas, ropas de vestir e otras cosas que consigo leuare": Ferdinand the Catholic, Barcelona, 30 June 1493, in Torre, Documentos, 4:232-33.

6 "A Don Cach, moro, embaxador del illustre rey de Tuniz, a nos embiado, que en qualquier ciudat o villa marítima de nuestros reynos y señoríos, adonde mejor visto le sea, el, con siete o ocho moros, los nombres de los quales queremos hauer aquí por expressos, puedan ir en Barberia, con qualquier fusta, o nauio de christianos, con todas sus ropas, dineros, bienes y mercadurias": Ferdinand the Catholic, Segovia, 3 September 1494, in Torre, Documentos, 4:531-32. 
Four years later, in 1498, the king ordered a payment of 4,870 sueldos in Valencian coin to a new ambassador from the "sheikh of the Gribens [or Gribus]," possibly meaning Djerba:

Azmet Abencucuma, a Moorish ambassador sent to us from the sheikh of the Gribens, four thousand eight hundred seventy sueldos, royal coins of Valencia, which we graciously ordered given to him to help with the cost of returning to the island of the Gribus. ${ }^{7}$

In 1499 Ferdinand approved a grant to Gonzalo of Burgos for "ten thousand maravedis in coin of our kingdom of Castile, which we send him to help with the expenses of certain Moors, ambassadors from overseas." North African envoys must have fallen into financial straits, since the monarch also ordered the viceroy and the procurer of Majorca "to give to three Moors ... for clothing themselves and for returning [to their country] what you think is right, so they may leave contented." 9

In 1512 Sheikh Lahacen, an ambassador from the ruler of Tunis, was in Castile. He was given leave to travel through the kingdom with his baggage and foodstuffs, together with all the Muslim slaves he was able to ransom. ${ }^{10}$

There were surely many other embassies of which we are unaware, at least at the present time. The Capitulation signed in 1521 between the king of Tlemcen and the second Marquis of Comares (in the name of the Spanish monarchs) stipulated that if the Maghrebi sovereign

should wish to send Their Majesties his ambassadors or messengers with or without gifts, or to complain of any wrong done in the matter of his rents or his vassals or any other thing that should be consulted with Their Majesties, no present or future captain general of this kingdom or his lieutenant, nor judicial officers, nor any other person may impede their travel or that of those who travel with them or whom they bring. Rather, they shall be offered the ship of the line needed for their journey at a

"Azmet Abencucuma, moro embaxador a nos embiado por parte del xeque de los Gribens, quatro mil ochocientos setenta solidos, moneda[s] reales de Valencia, los quales nos graciosamente le mandamos dar para en ayuda de costa de voluer a la isla de los Gribus": letter from Ferdinand the Catholic, Toledo, 4 May 1498: Torre, Documentos, 6:74.

8 Letter from Ferdinand the Catholic, Granada, 10 September 1499:Torre, Documentos, 6:200.

9 Ferdinand the Catholic, Granada, 5 August 1499: Torre, Documentos, 6:196-97.

10 Permission was granted in Burgos on 20 January 1512. That February a license was given to Alalia Bulia from Oran, who had been a slave, to travel to Tunis with the ambassador's retinue: Cortés Alonso, La esclavitud en Valencia, 135-36, 419, 422. 
reasonable price, and if they bring merchandise the duties owed on it shall be paid for them. ${ }^{11}$

As of now we know of only one ambassador sent to the Peninsula: in 1533, when in the town of Espejo in Córdoba another Capitulation was signed between the Marquis of Comares, governor and captain general of Tlemcen and Tunis, and Alcaide Boavdila, the king of Tlemcen's ambassador. Boavdila declared his intention not to return home until the agreement was signed, "until I depart in the proper way, even if I were to be here my whole life and spend every penny I have."12 Further Capitulations repeated almost the same terms: in 1545 it was added that a ship from Oran or Mazalquivir would be provided to the ambassador, and the same was stated in 1546 when the agreement was signed by the Count of Caudete and King Muley Hamete of Tlemcen. ${ }^{13}$

In July ${ }_{1531}$ Selim Ben Muça Azahui, during a visit to Spain, came to the court of Castile, presided over at that time by the Queen-Empress Isabella of Portugal; he gave her a message from Mohammed Xeref, sheikh of the Arabs in the Oran region. In early 1532 he returned to court bearing letters from the military governors of that region: Hamida el-Abda, Mohamed el-Anvari, Mohamed ben Marzok, and the sheikhs of the Husayn family. On this occasion he was accompanied by an official from Oran, and the group met in Córdoba with the captain-general of the Oran presidio, who lived in the city. When the queen received them in Medina del Campo they asked her for help in capturing Algiers and defeating the Turks. ${ }^{14}$

From the mid-15oos to about 1629 there were negotiations and exchanges of ambassadors and envoys between the Spanish monarchy and the reigning dynasty in Kuku (Kabylia). In 1542 the brother of the king of Kuku, with several companions, touched at Majorca and Tarragona aboard a Spanish vessel as they went in search of the Spanish king: "the brother of the king of Kuku who

11 "Quisiere embiar a sus Magestades sus embaxadores o mensajeros con presentes o sin él, o se quexar de algún agravio que se les aya fecho en lo que toca a sus rentas o a sus vasallos o en otra qualquier cosa que le cumple consultar con Sus Magestades, que el capitán general que es o fuere en este Reyno o su lugarteniente, ni la justicia, ni otra persona alguna no le pueda ympidir el viaje a ellos ni a los que con ellos fueren ni a los que llevaren, antes les mandará dar navío, tasándoles el preçio justo, que por su viaje oviere de aver, e pagando, si llevaren mercaderías, los derechos que dellas devieren": Mariño, Tratados internacionales, $7-26$, quotation at 19 .

12 Mariño, Tratados internacionales, 28-37, quotation at 30.

13 Mariño, Tratados internacionales, 122-29 and 16o-69, references at 127, 167.

14 They also hoped to free themselves from the rulers of Tlemcen, Abud Allah and his son Mohammad, who were rivals for the throne: La Véronne, "Memorial de Diego del Castillo." 
disembarked in the island with a galleass coming from Bougie, on his way to his Majesty as ambassador."15 In the early seventeenth century Sidi Amar ben Amar, the sovereign of Kuku and an ally of Philip III against the Regency of Algiers, sent several ambassadors or commissioners to the Spanish court. Some of them were Spaniards, including one priest, and almost all of them put in at Majorca and Valencia.

In early 1602 Aboul Malik arrived with letters requesting an alliance against Algiers and a proposal for increased trade between the parties. In July 1602 Sidi Mahomet Benamar and his son Ali came and converted to Christianity with the names Ramón and Felipe de África, respectively. In the following year two prominent men of Kuku, Sidi Amar the Elder and Sidi Abdelmalek, came to Majorca and passed through Valencia on their way to see Philip III, who received them in May. In July they returned to the island and remained there for some time - it was hard to find transport back to their home country, and they showed no interest in leaving. Amar the Elder was criticized for devoting himself to "loose women and dissolute living," and more seriously, for conveying false information to his sovereign. In the end both men converted to Christianity, making it possible that they never returned home. The previous four visitors were still on Majorca in 1604, but one of them must have left for North Africa in February of that year: there is a record of the departure of "the ambassador from Kuku and a Moor who goes with him." The ruler of Kuku must have been pleased with his four envoys' actions, since he sent another, Musa Ben Amat, late in $1603 .{ }^{16}$ This may have been "the Moor Muza," who returned to Kuku in 1605 with gifts and sixty-two thousand reales de vellón from the viceroy of Majorca for the North African king, having performed his mission well:

And the Moor Muza accomplished well what he was ordered, for within a very short time he gave your letters to that king. And he now returns by order of his master to give the said letters and a report on the state of those affairs. ${ }^{17}$

Muza came back to the island with letters from his sovereign, and he may be the same person who brought a letter from the viceroy of Majorca to the king

15 They arrived in early July 1542: Dietari del antich consell, 4:103-04 (1534-1562). For more see Seguí Beltrán, “¿Unas islas asediadas?”, 72.

16 Seguí Beltrán, “¿Unas islas?”, 73-80; Rodríguez Joulia Saint-Cyr, Felipe III, 43-68.

17 "E el moro Muza cumplió bien lo que se le ordenó, pues en menos horas de las que ofreció dio las cartas de V.M. a aquel rey y vuelve agora por orden de su amo a dar las dichas cartas y cuenta del estado de aquellas cosas": Deyá Bauzá, "La política mediterránea," 81. 
of Spain in Madrid. We know that a new representative of the king of Kuku, Mohamed, arrived in Majorca in $1606 .{ }^{18}$ There is more information for 1608 , when in April two Majorcan vessels set out for the coast of Kabylia, one of them bearing Muza. As they approached their landing site they grew uneasy about the party that had come to receive them, and sailed away suddenly after only four North Africans had boarded: Amardan, Amet Betxalin, Amet Gran, and Ali. One of the Spanish captains reported that they had not thrown the Moors back into the sea because they could not swim, and in fact a servant of the ambassador's who had jumped overboard was drowned. When the ship returned to Palma, on Majorca, the king ordered that the Moors be well treated because they might be exchanged for five Christians being held in Kuku; but the exchange was delayed and the fortifications of Palma were strengthened. In June 1609 one of the four Moors, Ali, left Majorca for North Africa. We know that in 1610 the king of Kabylia sent a new embassy to Majorca, but the Spanish court does not seem to have held it in much regard. The mission was intended only to recover the remaining three men from the earlier incident, who were turned over to Muza Ben Amat in $1615 \cdot{ }^{19}$

Finally we can mention the presence on Majorca of "the Moorish king," a son of the deposed ruler of Bougie, who led the confederation of the Banu Abbas. At the end of 1562 he sailed from the island for North Africa. ${ }^{20}$

The embassies we have described were connected to Spanish expansion in the central and eastern Maghreb, marked by the struggle between the Ottoman and Spanish empires for control of the region. After Spain was defeated in Tunis in 1574 and finally abandoned its hopes of conquering Algiers in the early 16oos, there were no new delegations for a long time. The truth was that as the monarchy's strength waned, neither its support of the Hafsids nor its considerable shipments of arms and equipment to the king of Kuku were able to do much good. ${ }^{21}$

In the mid-15oos Spanish policy focused particularly on Morocco, resulting in a series of diplomatic exchanges between the two countries. ${ }^{22}$ Some embassies came from Morocco's Atlantic coast and brought representatives

18 Rodríguez Joulia Saint-Cyr, Felipe III, 72-73.

19 Seguí Beltrán, “¿Unas islas?”, 73-80; Rodríguez Joulia Saint-Cyr, Felipe III, 43-68; Deyá Bauzá, "La política mediterránea."

20 Seguí Beltrán, “¿Unas islas?”, 72-73.

21 Deyá Bauzá, “La política mediterránea”; Seguí Beltrán, “¿Unas islas?”, 80-82; Boyer, "Espagne et Kouko"; Rodríguez Joulia Saint-Cyr, Felipe III y el rey de Cuco.

22 They must have been more numerous than has been thought, but for now we have documented only those of 1586, 1614, 169o, 1766, 1779, and 1792 (two): Valensi, Ces étrangers, 287. 
of nomadic tribes from the western Sahara. In February 1499 the governor of Gran Canaria received "Mohamad de Maymon, lord of Tagaos [Tagaoust]," and "Hamet, captain of the city of Yfran [Ifrane] and its territory," who represented the residents of the fortress of Yfni and the lords of Tamanart and its region. All declared themselves vassals of the Catholic Monarchs. ${ }^{23}$

From the Mediterranean coast of Morocco, two envoys came to Prince Philip in $155^{1}$ from Mulay Amar, "king of Debdou," who ruled a region of eastern Morocco relatively close to Tlemcen and Melilla. He had lost his throne to the Saadids, although he managed to recover it. In exchange for swearing fealty to the monarchy he asked for assistance - of which he received very little, at least in military equipment. ${ }^{24}$

Most ambassadors, however, were dispatched by sultans of the Moroccan Empire. In 1582 Amete Votarbo arrived at the Spanish court, probably by way of Lisbon, charged with ransoming Muslim slaves; he managed to return home with thirty-four of them. ${ }^{25}$ We assume that he was the same envoy who came back in 1586 and whom C. Tarruell identifies under several similar names (Botarbo, Voytade, Botaybo, and Botayo); he was an alfaqueque or ransoming agent of Morisco origin from Tetouan. ${ }^{26}$

When a new civil war broke out in Morocco in the early seventeenth century, different rulers or sultans of the empire sent envoys and emissaries to Spain. In 1614 Muley Abdala, son of Muley Xeque who had died the year before, wrote expressing his wish to maintain good relations with Philip III: "We desire to live in the same peace and amity that our father shared with you and your king, which I will always preserve and guard during my time, and never shall there be anything but love and friendship between us." In July he told the Duke of Medina Sidonia that he was sending two of his governors, Almanzor Benaaya and Audarraman el Majauregui, to discuss their mutual "fondness and friendship," which they would speak of "with their tongues" because "these are not matters to be written by the hand of a scribe." In September of that year he expressed himself satisfied that the Duke had received them "with great love, and had treated them generously and given them everything necessary,"

23 Caro Baroja, Estudios mogrebinos, 59-8o, esp. the sections "Los viejos señores del Nun y el Drá" and "Las actas de 1499 y las tierras del Nun y el Drá." Also Rumeu de Armas, España en el África Atlántica, 275-304, and España en el África Atlántica. Documentos, 73-78.

24 Alonso Acero, Sultanes, 77-79.

25 There is information about him in AGS, GA, leg. 210, doc. 112-13, Madrid, 17 February 1587. The passport that allowed the thirty-four slaves he freed to leave the Peninsula is dated 27 October 1582 in Lisbon: AGs, GA, leg. 38, fols. 47r-48r: see these in Tarruell, "Circulations," 267-68.

Valensi, Ces étrangers, 287. 
adding that he awaited their return eagerly in the knowledge that the Spanish monarch would have welcomed them. More letters were exchanged between October 1614 and January 1615, one of which informed Philip III that on their return to Tangier the two men had told of "the honor and favor that the Duke of Medina Sidonia showed them by order of Your Majesty," leaving them "contented and grateful."27

Muley Zidan, who was contending with Muley Abdala for the throne, wrote to the Duke of Medina Sidonia in November 1614 claiming the possessions of his deceased brother Muley Xeque. His letter explained that in his country, as laid down in the Quran, all a man's children should inherit from him (though females had only a half share). As proof he attached a statement signed by twenty-three Moroccan jurists, judges, and notaries. ${ }^{28}$

The Spanish monarchy and Safavid Persia exchanged embassies to try to forge an alliance as common enemies of the Ottoman Empire; here we will mention only those that the shah sent to the Spanish court. ${ }^{29}$ In 1599 Persia sent a delegation to Europe led by the Englishman Anthony Sherley (who had reached the Safavid court in 1598 to form a common front with Shah Abbas against the Ottomans) and the Persian Hussein Ali Beg. ${ }^{30}$ Their retinue included four gentlemen: Uruch Beg as secretary, the ambassador's nephew Ali Quli Beg, Hasan Ali Beg, and Bunyad Beg. There were also fifteen servants, five interpreters, two Portuguese friars, and thirty-two camels. This impressive group entered Barcelona by way of Perpignan on 15 July 1601 , when a municipal document described the scene:

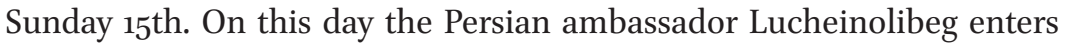
Barcelona; he was coming from Rome and goes to Valladolid to negotiate the alliance with our lord King. Nine Persians of the company entered accompanied by twelve light horses from Perpignan; they had come from

27 The early letters requested the return of the deceased Muley Xeque's effects, which were in the Spaniards' possession; a letter of July 1614 reported that they had been sent. Other letters are dated 17 October 1614 and 11 January 1615 (two): García-Arenal et al., Cartas marruecas, 348-66, 377-79.

28 Muley Zidan to the Duke of Medina Sidonia, 11 November 1614: García-Arenal el al., Cartas marruecas, $367-76$.

29 Martínez Shaw, "Cuatrocientos años de la embajada"; Rubies, "Political Rationality"; García Hernán et al., The Spanish Monarchy and Safavid Persia; García Hernán, "Persia en la acción del Papado"; Gil Fernández, El imperio luso-español y la Persia safávida, vols. 1 \& 2, and "Tras la huellas de Don Juan de Persia"; Cutillas, "Las Relaciones de Don Juan de Persia"; Mehrad, "Relaciones diplomáticas."

Davies, Elizabethans Errant; Penrose, The Sherleian Odyssey; Ross, Sir Anthony Sherley. 
France. The governor with eight or ten gentlemen came out to receive them, and they spoke through an interpreter. And the ambassador rode on a horse sent him by the viceroy, and wore a tunic of crimson velvet with a lining of sable, and bore in his hand a scepter that must have been a palm and a half long. And all those of his company wore turbans on their heads made of fine fabric of different colors. ${ }^{31}$

The visitors were received by the viceroy of Catalonia and feted for ten days. After three days in Zaragoza with an equally warm welcome, they arrived on 13 August in Valladolid, where the Persian ambassador was accorded the same honors as the French one. Two days later Philip III received him at court. ${ }^{32}$ Having discharged their mission, Hussein Ali Beg and his companions left Valladolid on 11 October 1601 on their way to Portugal, the first leg of their return journey to Persia; but they lost the chief envoy's nephew, Ali Quli Beg, who appealed to the Jesuits to receive him as a convert.

The whole retinue, growing ever smaller in number, sparked enormous curiosity as it passed through Segovia, Balsaín, El Escorial, the palaces at La Zarzuela and La Casa de Campo, Madrid, Aranjuez, Toledo, Trujillo, Mérida, and Badajoz. In Mérida, as a crowd of the curious jostled to enter the Persians' rooms and see them better, the faqih Amir was stabbed to death as he tried to block the door, and the assassin escaped under cover of darkness. The exhausted embassy reached Lisbon in November 1601. There they caused problems for the local viceroy, since some were accused of lust, greed, and excessive winedrinking; they tried to take away the hangings and silver plate that decorated their rooms, and also to buy lances, swords, and arquebuses. The viceroy refused those purchases, which were forbidden on religious grounds. ${ }^{33}$

In late 1606 a new embassy arrived, led by Pakize Iman Quli Beg. The chancellor of the Persian court reached Lisbon in September of the next year, bearing a letter from Shah Abbas to Philip III, and departed for home in September 1608. A delegation led by Ali Quli Beg (whom the shah called "one of my

31 "Diumenge xv. Dit dia lo ambaxador de Persia Lucheinolibeg entra en Barcelona, venia de Roma y va a Valladolid per tractar la lliga amb lo Rey nostre senyor: entraren nou perças de companya acompanyats de dotze cavalls lleugers de Perpinya, eren vinguts per França, isquels a rebre lo governador ab vuyt o, deu Cavallers y parlaren per interprete E lo dit ambaxador anava a la gineta ab un cavall que li envía lo virey, aportava una cota de vellut carmesí ab forros de martas y en la ma un septre que devia tenir palm y mig de llarch y ell tots los de sa companya aportaven turbants al cap fets de telilla de diferentes colors": Dietari del Antich Consell Barceloní, 364. 
confidants, whom I usually send with such embassies") and Francisco de Acosta reached Rome in September 16og; it carried letters for both Philip III and the Pope. ${ }^{34}$

Robert Sherley, brother of Anthony, and the Persian Denguis Beg left Persia in the spring of 1609 as co-leaders of a new embassy to Spain. They received permission to pass through Rome, and arrived at the Spanish court in early 1611. One member of the group was a commercial envoy, Coja Regeb, and there were also many servants. Leaving Spain in March 1612, the group went on to Lisbon where the ambassador complained to the inspector of the treasury: he had not received the respect he deserved, and claimed that the ministers in Portugal "are happier to see Moors from Barbary than they are to see me." It appears that Juan de Persia, who had been a member of the delegation of 1601, interpreted for Denguis Beg's group on this occasion; he had converted to Christianity in the interval. On returning to Persia in 1613 Denguis Beg was executed by order of Shah Abbas, and we wonder if his "crime" had been to allow members of his embassy, including the secretary, to remain behind in Europe as Christians. ${ }^{35}$

All these embassies that sought to create a European-Persian alliance against the Ottomans came to naught. At most they may have made Constantinople feel a certain uncomfortable pressure at the prospect.

Ahwaz (Oeza in Spanish sources) was a kingdom located between the Ottoman and Persian Empires. In July 1617 an embassy from its king or sheikh, Seyyed Mobarak (Asic Mobarac or Mombareca), arrived in Naples. Its two leaders were a Portuguese and "Sheikh Ferhan, a Christian, who is one of its most prominent figures and our ambassador." They too hoped for a military pact against the Turks, to dislodge them from Basra and Bahrein; they went on to Madrid on 3 October but seem to have had no success. ${ }^{36}$

The Spanish-Persian approach surely favored Spanish-Ottoman approximation. An Ottoman ambassador arrived in Barcelona in June $1625 .{ }^{37}$ The Porte sent another ambassador to the Spanish Court in 1625; he landed first in Barcelona and then went on to Madrid: "The embassy of the Grand Turk was accomplished and arrived this month at the court of the king our lord. The Turk requested his friendship and gave him a fine present, with a letter issued in Constantinople, on the first of March." ${ }^{38}$ In the mid-16oos the Ottoman caliph

34 Gil Fernández, El imperio, 1:171-74.

35 Gil Fernández, El imperio, 2:182-219.

36 Gil Fernández, El imperio, 2:417-21.

37 Pujades, Dietari, 3:218.

38 "Embaxada del gran Turc fou feta y arribada en aquest mes a la cort del rey nostre señor, demanant-li lo Turch sa amistat y fent-li un grant present ab carta despedida en Constantinoble lo primer de marts": Pujades, Dietari, 3:218. 
dispatched Hamete Aga Mustafarac, Pasha of Cairo, to the court in Madrid; he arrived in Valencia in August 1649 and in Madrid in September. The street where he lived near the Calle de Alcalá was called "Turk Street" (la calle del Turco) for two centuries afterward. Philip IV received him on September 15. As often happened, his presence in the city aroused both expectation and conflict: he decided to visit a convent of nuns of Calatrava, near his lodgings. They received him kindly, but criticism of the visit reached the Council of State; on 17 October its secretary, Pedro Coloma, wrote to the Marquis of Mirabel:

It having become known in the Council of State that the Turkish ambassador has gone to the convent of the nuns of Calatrava, where he was admitted and greeted with music, I am ordered to tell Your Excellency that the Council feels it is not right to allow him any occasion at all to go to holy places. And may Your Excellency be so good as to advise those religious women to correct this entry, for we understand that he intends to return there. ${ }^{39}$

The nuns were forced to apologize for having sung "two serious songs" for the ambassador, even though all of them had been wearing "hoods, their faces covered with masks." This incident led to censure of the Turks' customs, as they were suspected of seeking contact with prostitutes in Madrid. Philip IV therefore ordered:

Through several decrees of mine, and especially through one dated 15 January of this year, I have instructed you to order the watchmen to take great care to patrol the street and house of the Turkish ambassador, because of the news I have heard of the excesses and sins that were being committed there, proceeding from the liberty and license of commerce between the Moors and certain Christian women who entered there. And that the first [woman] you lay hands on, of those who were causing the scandal, should be made a strong example of, naming her publicly ...

"Habiendose entendido en el Consejo de Estado que el embajador turco ha ido al convento de las monjas de Calatrava, donde ha sido admitido y festejado de música, he tenido orden de decirlo a V.E. y que el Consejo siente que no es bien permitirle por ningún caso que vaya a lugares sagrados y que V.E. podría servirse de hacer advertir a aquellas religiosas que se remedie esta introducción, porque también se ha entendido que stá en propósito de volver allá": Espadas Burgos, "Andanzas madrileñas," 83-87. For a comparative study of the Persian and Ottoman embassies see Hernández Sau, "Perspectives on Iberian-Safavid Relations"; Conde Pozas, "La embajada turca en Madrid”; Díaz Esteban, "Embajada turca a Felipe IV." 
and so I instruct you to call the watchmen and order them to keep their watches strictly, or in any form that seems fair and promotes continuous patrols by that Turk's house. And let any woman who enters it be arrested and held up as the stern example that such great wickedness calls for. And two days from now you must not fail to give me a very exact account of the measures you have taken and what may result from them.

The decree ordered that a house in the Calle de Alcalá, where such deeds were supposed to be taking place, be closed:

... and in a house that they call "the little taverns of Parla," where every night fifteen or sixteen women, with others who live a debased life, meet many men from the household of this Turkish ambassador as well as some English ones, and grave excesses, scandals, and offenses against God are committed. ${ }^{40}$

It does not seem that this embassy achieved an improvement in HispanoOttoman relations. It might not have been as representative as it claimed, at least in the opinion of the Moroccan ambassador Muhammad b. Abd alWahhab al-Gassani, who visited Madrid years later:

The Turkish embassy that came to Spain forty years ago claimed to come from Constantinople, but it had actually been sent by one of those madmen who wanted to create difficulties for the sultan of Constantinople. ${ }^{41}$

40 "Por los diferentes decretos míos y especialmente por uno de quince enero deste año os he mandado que ordenáseis a los Alcaldes que estuviesen con sumo cuidado de rondar la calle y casa del Embajador turco por la noticia con que me hallaba de los excesos y pecados que en ella se cometían procedidos de la libertad y desenvoltura del comercio con los moros de algunas mujeres cristianas que en ella tenían entrada y con la primera que se viniese a las manos, de las que causaban el escandalo se hiciese severa demonstración anotándose públicamente ... y asi os mando que luego llaméis a los Alcaldes y les encomendéis que precisamente atiendan por sus turnos o en la forma que sea justa y pareciere mejor a la ronda contina de aquella casa del turco y que cualquier mujer que entrase en ella se prenda y haga la demostración rigurosa que pide tan enorme maldad y que dende en dos días indispensablemente me deis cuenta muy particular de las diligencias que se hicieren o de los que dellas resultaren. ... [Y] en una casa que llaman las tabernillas de Parla, adonde todas las noches se juntan quince o dieciséis mujeres y gran cantidad de hombres de las casas de este embajador turco, de los de Inglaterra y otras de malvivir y se cometen graves excesos y escándalos y ofensas a Dios": Espadas Burgos, "Andanzas," 83-87.

41 "La embajada de los turcos que vino a España hace cuarenta años, han pretendido que llegaba de Constantinopla, pero la verdad es que había sido enviada por uno de esos locos 
Embassies from Muslim countries resumed toward the end of the seventeenth century. In 1690 the Moroccan Sultan Muley Ismail sent his vizier, Muhammad b. Abd al-Wahhab al-Gassani, to the Spanish court. ${ }^{42}$ It has been debated whether his only objectives were to recover some Arabic manuscripts and ransom several hundred Muslim captives, ${ }^{43}$ or if he also hoped to negotiate a peace treaty. While there is no relevant documentation, we must consider the state of Hispano-Moroccan relations at the time. The Spanish Empire, governed by Charles II and the various factions of his court, was in steep decline, while Emperor Muley Ismail was one of Morocco's most remarkable rulers of the Early Modern period. He modernized the army and carried out a vast plan of fortifying his principal cities, including those along the coast. He demonstrated his power by conquering three fortified ports belonging to Spain or England: La Mamora (i.e., Mehdya, 1681), Tangier (1684), and Larache (1689). His self-confidence - and perhaps inflated reliance on his treaty with the French was such that he requested the hand of one of Louis XIV's daughters. We wonder, therefore, whether his envoy al-Gassani had a more important mission than taking several hundred captives and a few texts back to Morocco. Did he seek to have a treaty signed, and if so, what was he prepared to offer in return? We must recall that Morocco's seige of Spanish Ceuta, launched in 1694, lasted until Bourbon troops finally lifted it in $1727 .{ }^{44}$

Al-Gassani and his train embarked in three ships at Ceuta in December 169o, and from Gibraltar a settee conveyed them to Cádiz. According to custom they were received with great pomp first in that city 45 and then in the others through which they passed, including of course on their arrival in Madrid. ${ }^{46}$

que querían crear dificultades al sultán de Constantinopla": García Mercadal, Viajes de extranjeros, 4:303. In al-Bustani's translation, the embassy "came from some unscrupulous men who wished to damage the reputation of the kings of Constantinople": al-Gassani, $E l$ viaje del Visir, 42.

42 Beck, "The Travelogue of a Moroccan Ambassador"; Ben Hadda, A Moroccan Ambassador; García Mercadal, Viajes de extranjeros; Arribas Palau, "De nuevo sobre la embajada"; Vernet, "Embajada de al-Gassani"; al-Gassani, El viaje del Visir; Sauvaire, Voyage en Espagne d'un ambassadeur; Stanley, "Account of an Embassy from Morocco."

These are the only two purposes the ambassador mentions in his memoir. I use the translation of "Un embajador marroquí" included in García Mercadal, Viajes de extranjeros, but have also consulted al-Gassani, El viaje, and Paradela Alonso, El otro laberinto.

44 Abitbol, Histoire du Maroc, 234-53.

45 In Cádiz the ambassador was well treated by the governor and given a tour of the city by carriage. There was also a warm welcome in El Puerto de Santa María: al-Gassani, El viaje, $5^{-11 .}$

46 In Madrid "we found that a multitude of people had come out to receive us, some in carriages, others on foot and still others on horseback." On the day of the royal reception "we 
Arabs who visited Spain viewed it with admiration and nostalgia; this was especially true of al-Gassani, who was of Andalusi descent. It was an "archaeological" nostalgia for a lost al-Andalus that had once belonged to his ancestors. ${ }^{47}$ With emotion and fascination he visited the principal Islamic monuments like those of Córdoba and Toledo, ${ }^{48}$ and recognized that Spaniards valued them as well. ${ }^{49} \mathrm{He}$ often expressed the impossible dream that the monuments might return to Islamic control..$^{50}$ That was a wholly conventional political discourse at the time, but again, it occurred against the backdrop of the Moroccans' seige of Ceuta (1694-1727).

Al-Gassani spoke of other traces of Islam in Spain, including visits by Moroccan exiles to the Peninsula such as that of Muley Xeque in the early 16oos. ${ }^{51}$ Surprisingly, he showed little interest in the Morisco uprising. ${ }^{52}$

Throughout his journey al-Gassani found people who assured him (at any rate he believed them) that they descended from Spanish Muslims; he met them in Jerez, Lebrija, Utrera, Marchena, Linares, and Andújar. In Jerez, "the greater part of the population traces its origin to the Andalusis and its principal figures who turned Christian"; in Lebrija, "some residents persuaded us that they descended from Andalusis, through a certain word they cannot pronounce except by disguising their language. It is certain that most of its inhabitants trace their origin to the Muslims of Spain. But with the passage of time they have been educated under the shadows of impiety"; in Utrera, "Most of its residents descend from the Andalusis ... A daughter of the city's governor and a daughter of the judge ... are two young women descended from the Andalusis and related to the last king of Granada"; in Marchena, "Its inhabitants are pleasant people; they include some who trace their origin to the Muslims of

found the residents of the city all gathered together, so much so that it was very hard to reach the palace": al-Gassani, El viaje, 41, 44.

47 Paradela Alonso, El otro laberinto, $76-77$.

48 In Córdoba he spoke particularly of the mosque, "so celebrated and well known"; in Toledo, of the many traces of Islam, especially its mosque. He said of Illescas that the town still held signs of its Muslim past: al-Gassani, El viaje, 20-26, 94-96.

49 "Spaniards do not deny the importance of Muslim mosques such as those of Toledo, Córdoba, and Seville, which are very famous": al-Gassani, El viaje, go.

50 Among other instances, in Seville, "May God return it to the community of Islam!", and in the mosque of Toledo, "May God return it to Islam!": al-Gassani, El viaje, 45, 94-96.

51 In El Puerto de Santa María he knew of "a large house where Sultan el-Sheikh had stayed, son of Sultan Ahmed el-Dahabi, known as al-Dakhil because he entered Spain": alGassani, El viaje, 13.

52 Al-Gassani, El viaje, $52 \mathrm{ff}$. Paradela Alonso notes that three Moroccan ambassadors who visited Spain in the seventeenth and eighteenth centuries - al-Gassani, al-Gazzal, and Ibn Otoman - all tiptoed around the topic of the Morisco tragedy: El otro laberinto, 91. 
Spain"; in Andújar, "It is highly probable that the population of Andújar comes from the Muslims of Spain [al-Andalus], and most descend from the Ulâd-esSarrâdj [Abencerrajes], who embraced Christianity during the reign of Sultan Hasan, the last king of Granada"; in Linares, "Most of its inhabitants descend from al-Andalus." ${ }^{\prime 3} \mathrm{He}$ believed that there were many descendants of Muslims in the regions he visited, and when he came to Andújar:

These people are very numerous in these districts; their number is incalculable. Among them some claim that genealogy while others do not. There are even some who are horrified to have it spoken of. Those who repudiate that ancestry and refuse to acknowledge it claim to come from the mountains of Navarre, very far from Castile, where the remaining Christians took refuge after al-Andalus was conquered by the Muslims. ${ }^{54}$

N. Paradela observes that, while al-Gassani may have met an occasional cryptoMuslim, what he took as proofs of Islamism were probably no more than courteous and cordial gestures extended to a distinguished traveler. ${ }^{55}$

Al-Gassani pointed out that many of these supposed descendants of Muslims belonged to the minor nobility:

53 Jerez: "la mayor parte de su población trae su origen de los andalus y de sus notables que se hicieron cristianos." Lebrija: "algunos habitantes nos confirmaron en la idea de que descendían de los andalus, por cierta señal que no pueden enunciar más que con la ayuda de un lenguaje embozado. Lo más seguro es que la mayor parte de sus habitantes traen su origen de los musulmanes de España. De todos modos, el tiempo ha transcurrido y han sido educados en las tinieblas de la impiedad." Utrera: "La mayor parte de sus habitantes son descendientes de los andalus. ... Una hija del gobernador de la ciudad y otra del juez ... son dos muchachas salidas de los andalus y de la familia del último rey de Granada." Marchena: "Sus habitantes son gentes afables; hay entre ellos quienes traen su origen de los musulmanes de España." Andújar: "Según toda probabilidad la población de Andújar procede de los musulmanes de España (andalus), y el mayor número procede de los Ulâd-es-Sarrâdj (abencerrajes), que abrazaron el cristianismo bajo el reinado del sultán Hasán, último rey de Granada." Linares: "La mayor parte de sus habitantes se compone de descendientes del Andalus": García Mercadal, Viajeros extranjeros, 289-96; al-Gassani, El viaje, $15^{-17}, 28,3$.

54 "Estas gentes son muy numerosas en estos distritos; su número es incalculable. Entre ellos, los unos reivindican esa genealogía y otros no. Hay incluso algunos a quien les horroriza oir hablar de ella. Los que repudian esa descendencia y rechazan el reconocerla se pretenden descendientes de las montañas de Navarra, montañas alejadas de Castilla, y en donde se refugiaron los restos de los cristianos cuando la conquista del Andalus por los musulmanes": García Mercadal, Viajes extranjeros, 295; al-Gassani, El viaje, 29.

Paradela Alonso, El otro laberinto, 88-89. 
Most of the descendants of the Christianized [Muslims] in Andújar are among the city's nobles; but their nobility is not valued as much as the kind transmitted by inheritance, like the titles of duke, count, and so forth. For these Abencerraje converts, all the nobility they enjoy today consists of inheriting the privilege of wearing a cross on the shoulder of their garment. The positions open to the remaining members of the family are in the secretariat, city government, the police, and others that carry no great importance or authority. ${ }^{56}$

These observations of al-Gassani's are not surprising. J. Amelang has shown in a brief but excellent summary how the purity-of-blood statutes were applied unevenly in the various institutions that adopted them, so that descendants of Moriscos and Jews could evade them fairly easily. ${ }^{57}$

One of the individuals spoken of was a resident of Orcera who approached the ambassador to tell him that "he was joined in great friendship to Don Alonso, grandson of the King of Granada," who had asked him to accompany the visitor through the Sierra Morena, always a dangerous route because of bandits. The man assured al-Gassani that he had been a highwayman himself, but had retired to await the king's mercy; and that, "if you were well disposed toward the journey, I would go with you to the home of Muley Ismail and request a letter for the king of Spain so that he can grant me my pardon." ${ }^{58}$ In the Early Modern age it was more common than we might imagine to approach the sultan of Morocco for a pardon or other favor from the Spanish monarch.

Al-Gassani had the impression that the status of minor nobility - which he associated with "purity of blood" - was granted only to "pure Christians," those who could prove seven generations in the faith. It was given also to

those who, being descended from al-Andalus and belonging to the great families of their nation, have later become Christians for their

56 "La mayor parte de los descendientes de estos cristianizados que están en Andújar cuentan entre los nobles de la ciudad; de todos modos, su nobleza no es considerada igual a la que se transmite por herencia, como los títulos de duque, de conde y otros semejantes. Toda la nobleza de que gozan hoy consiste para los abencerrajes convertidos en cristianos en transmitirse por herencia el privilegio de llevar sobre el hombro una cruz dibujada sobre el vestido con que se envuelven. Las funciones de que están investidos los restos de esa familia son el secretariado, el gobierno de las ciudades, la policía y otras que no tienen ni una grande importancia ni una grande autoridad": García Mercadal, Viajeros, 295; alGassani, El viaje, 28.

57 Amelang, Vidas paralelas, 114-18.

$5^{8}$ In fact he accompanied al-Gassani for a day: al-Gassani, El viaje, 35-36. 
self-interest; then they are given this sign that shows that they originate in Islam; it is a sign of their nobility in the false religion. ${ }^{59}$

The Moroccan seems unaware that he is contradicting himself: he had just affirmed that Christians had to prove that their families bore no "spot or even a suspicion of Judaism or any religion other than the Christian."60

In Madrid al-Gassani met persons of a certain standing who enjoyed relatively good relations at court. One was Don Alonso, whom he describes as "a grandson of Musa, the brother of Sultan Hasan who was defeated in Granada"; Don Alonso "showed a liking for the Muslims he met, mentioned his lineage, and enjoyed hearing stories about Islam and its peoples."61 Another man, whose name he had forgotten, was a government secretary and claimed descent from the Abencerrajes:

One day in Madrid I met someone whose name I cannot recall just now ... .He paused and, after having repeated words of greeting, he and the ladies who were with him offered us great affability and attention. We replied to his courtesy in the proper way. Before departing he introduced himself, saying: "We are of the Muslim race, descendants of the Ulad-es-Sarraj." Later I inquired about him and they told me that he was attached to the Ministry of State as a secretary; he was responsible for reading applications, petitions, and other documents of that kind. A certain number of natives of Granada who had official posts there kept their residence in Madrid. They would come to see us in the company of Don Alonso, a descendant of the king of Granada, and they traced their origin to the race that lived in Granada. ${ }^{62}$

59 "Los que, descendiendo del Andalus y perteneciendo a los grandes de su nación, se han hecho después cristianos por sus intereses; entonces les han dado esa señal que indica que pertenecen en el origen al islamismo; esa señal es la de su nobleza en la mala religión": García Mercadal, Viajeros, 306; al-Gassani, El viaje, 47-48.

6o García Mercadal, Viajeros, 306.

61 Al-Gassani, El viaje, 16.

62 "Encontré un día en Madrid un personaje cuyo nombre no recuerdo en este momento. ... Se detuvo y, después de habernos saludado repetidas veces, nos testimonió, así como las damas que con él iban mucha afabilidad y atenciones. Respondimos como debíamos a su cortesía. Cuando quiso marcharse se dio a conocer diciendo: 'Somos de la raza de los musulmanes, descendiente de los Ulad-es-Sarraj.' A continuación me informé sobre él, y me contestaron que, agregado al Ministerio de Estado, con la calidad de secretario, era quien estaba encargado de leer las instancias, las peticiones y otros documentos del mismo género. Del mismo modo cierto número de habitantes de Granada, investidos en esa ciudad de cargos y de funciones, tenían su residencia en Madrid. Iban a vernos en compañía de don Alonso, uno de los descendientes del rey de Granada; hacían remontar 
The ambassador goes on to say that many Spaniards also took an interest in Islam:

There are many people among them who, if you speak with them and they hear about the true religion and straight path of the Muslims, show themselves well disposed toward Islam; they praise it, approve of it, and do not refuse to listen to its teachings, as we have witnessed more than once. It is their clerics and friars, those rebellious spirits, who are moved by the greatest hatred and whose hearts are the hardest; those despicable ones are the most stubborn in their impiety. ${ }^{63}$

Of the two official aims of the embassy - to recover Arabic manuscripts and ransom Muslim captives - we shall say little about the former; these were texts that "used to be in the libraries of Moors from Seville, Córdoba, Granada, and other places," and N. Paradela has already studied the issue issue at length. ${ }^{64}$

Al-Gassani paid closest attention to the Muslim slaves he met throughout his journey, and confessed that they were its principal object. In Cádiz he was met by

all the [Muslim] captives held by the city of Cádiz: men, women, and children also came to meet us. In transports of joy they recited the Muslim profession of faith aloud and asked God's blessings on the Prophet (may God bless and preserve him!), calling for our sovereign's victory, blessing the Prophet (may God bless and preserve him!), shouting with joy for our ruler, el-Mansûr billah [he who is saved by God]. We counseled them and promised them that our sovereign (may God assist him!) would not abandon them as long as he enjoyed divine favor. That day was a holiday for

su origen a la raza que estaba en Granada": García Mercadal, Viajeros, 295. In al-Bustani's translation the ambassador interjects, "May God help them to return to the right path and the true religion!": al-Gassani, El viaje, 25-26, 29-30. See also Paradela, El otro laberinto, 85.

63 " $[\mathrm{H}]$ ay entre ellos muchas gentes que, si se habla con ellos y oyen hablar de la verdadera religión y del recto camino en el que se encuentran los musulmanes, se muestran bien dispuestos para el islamismo, hacen su elogio, lo aprueban y no rechazan el prestar oído a sus enseñanzas, así como nosotros hemos sido testigo mas de una vez. Son sus clérigos y frailes, estos espíritus rebeldes, los que están animados del odio más vivo y tienen el corazón más endurecido; esos miserables son los más obstinados en su impiedad": García Mercadal, Viajeros, 295.

64 Most of the books being sought had actually belonged to Muley Zidan's library and had been seized at sea by the Spanish in 1612: Paradela Alonso, El otro laberinto, 65-71; Justel Calabozo, La Real Biblioteca de El Escorial; Derembourg, Les manuscrits arabes de l'Escurial. 
them because they received the good news of their liberation, which God would grant them by the hand of el-Mansûr billah - the more so because it was now true that our ruler (may God assist him!), in gathering all his Christian prisoners, had no other object or goal than to free the Muslims from the hands of the infidel enemy. ${ }^{65}$

The reception in Córdoba was similar:

As we drew near the city the residents came out to meet us, together with the captives held there, who spoke aloud the profession of the Muslim faith and called for the victory of our sovereign, el-Mansûr billah. The children of the Christians repeated the same cries as the Muslims. ${ }^{66}$

\section{And likewise in Madrid:}

There we met joyful, contented, and happy [Muslim] captives, proclaiming the profession of the Muslim faith aloud and reciting the shahada (act of faith) and blessings on the Prophet, may God bless and preserve him! and calling for victory for our sovereign el-Mansûr billah. The Christian children echoed their cries. ${ }^{67}$

65 "[T] odos los presos que guardaba la ciudad de Cádiz, hombres, mujeres y niños vinieron también a nuestro encuentro; transportados de alegría, proclamaban en alta voz la profesión de fe musulmana y reclamaban las bendiciones de Dios sobre el Profeta (¡al que Dios bendiga y le salve!), haciendo votos por la victoria de nuestro señor, bendiciendo al Profeta (¡que Dios le bendiga y le salve!), dando gritos de júbilo para nuestro señor, El Mansûr billah (el socorrido de Dios). Les dimos consejos y les prometimos que nuestro señor jal que Dios asista!, no los abandonaría en tanto gozase de favor divino. Ese día fue para ellos una fiesta a causa de la buena noticia que recibieron de su liberación, que Dios iba a concederles por la intervención del señor El Mansûr billah, tanto más que cuanto que había llegado a ser cierto para ellos que nuestro señor ¡al que Dios asista!, no tenía otro objeto y otra atención al reunir a todos los cristianos que estaban presos, que librar a los musulmanes de las manos del enemigo infiel": García Mercadal, Viajeros, 286-87; al-Gassani, El viaje, 11.

66 "Cuando estuvimos cerca de la ciudad salieron los habitantes a nuestro encuentro, así como los prisioneros que encerraba y que proclamaban en alta voz la profesión de fe musulmana y hacían votos de victoria por nuestro señor El Mansûr billah. Los hijos de los cristianos repetían los mismos gritos que los musulmanes": García Mercadal, Viajeros, 292-93; al-Gassani, El viaje, 42.

67 "Encontramos allí prisioneros alegres y contentos y alegres, proclamando en alta voz la profesión de fe musulmana y profesaban la xehada (acto de fé) y las bendiciones del Profeta, ique Dios le bendiga y salve!, y haciendo votos de victoria por nuestro soberano El Mansûr billah. Los niños cristianos repetían sus gritos": García Mercadal, Viajeros, 303; al-Gassani, El viaje, 42. 
Clearly those slaves enjoyed, at least for the occasion, considerable freedom of movement, and could also profess their religious faith in public. It is also striking that in all three cities there were men, women, and children in the crowd. Charles II received al-Gassani on 21 December 1690 and heard his proposal to exchange one hundred Spanish soldiers captured when Morocco retook Larache in 1689 for five hundred Muslims (although the initial request had been for one thousand). To prepare for an exchange the Spanish monarch ordered an inquiry into the number of Muslim slaves present in the kingdom at the time, but when al-Gassani left Spain in May 1691 he could not take any with him in spite of his efforts. Spanish authorities continued to add to the list of captives for several months after the ambassador's departure. ${ }^{68}$ We saw above that a census of Mulsim slaves was drawn up in Puerto Real in 169o, connected to the visit of the Moroccan ambassador to Spain. ${ }^{69}$ Everything indicates that there were not many slaves in Spain at the time, concentrated in just a few cities, though the matter calls for more thorough investigation.

Al-Gassani praised the Spanish systems of inns, posts, and hospitals. He was also impressed by the ferries at river crossings, Madrid's wide streets, and the gazette published in the capital. ${ }^{70} \mathrm{He}$ admired El Escorial, where he was able to view the books that the sultan was seeking. ${ }^{71}$ Nuns also interested him and he visited several convents - at least one in Linares and that of the Discalced order in Carmona, the latter at the nuns' request. As he was leaving, one sister asked him the meaning of a phrase he had used, "May God lead us in this way on the path of health!". He noted in his account that he replied, "To Hell - what a dreadful destination!".72

During his journey to Madrid and his stay there the Spanish tried to avoid any unpleasant incidents. Local authorities were ordered not to let his retinue stop over in one place for any reason, in the belief that fewer problems would arise and the visitors would enjoy better treatment. The memory of a Turkish ambassador's visit in 1649 was still alive:

68 Al-Gassani states that he gave the king a letter containing the sultan's request for five thousand books and five hundred captives, and that Charles, unsure of what to do, consulted his advisers. It was finally decided to send a thousand captives but no books: alGassani, El viaje, 57 .

69 Izco Reina, "El censo de moros de 169o."

70 In Sanlúcar a member of his retinue fell ill and refused to be taken to a hospital that was run by friars; nonetheless they visited him every day until he was cured. Al-Gassani, El viaje, 64 .

71 Al-Gassani, El viaje, 89.

72 García Mercadal, Viajeros, 297; al-Gassani, El viaje, 30, 32. 
When the ambassador came from the [Grand] Turk a guard was placed over him on the pretext of forming an escort, which was to prevent and impede any offenses against God by members of the court. And now likewise, though not in the form of a guard (since this man is an envoy, while the other was an ambassador), persons should be positioned to avoid the same problem - and with even more skill and cleverness, for it is said that the one provided in the past to thwart him was not sufficient.

In Madrid strict orders were given to allow no one, Muslim or Christian, into alGassani's chambers who was not a member of his retinue, and that "no women may enter his lodgings." ${ }^{73}$

Although al-Gassani complained that "the people mistreated him," he actually enjoyed freedom of movement and was not prevented from speaking with Muslims (free and enslaved) whom he met in Madrid and elsewhere. It is hard to see what "mistreatment" he could be referring to. Was it the taunts of Christian boys in Cádiz and Madrid, or the curiosity of people who pushed close to see him better? The ambassador felt a certain uneasiness toward Christian society, though many of his statements were stereotypical. On mentioning Spanish kings who had carried out the Reconquest, and those of the Hapsburg dynasty, he exclaims, "May God purge them from the earth!", "May God cause them to perish!", and "detestable race." Charles v was "one of the most terrible of the infidel kings" and his son Philip II "a scoundrel." His curses ("May God annihilate them!") extended to the Portuguese and French monarchs and to the Pope. ${ }^{74}$ But perhaps his outbursts were not purely rhetorical. As his retinue passed through Sanlúcar de Barrameda one of its members fell ill, and the friars who ran the local hospital proposed taking him there for treatment. After Al-Gassani refused twice, the friars visited the sick man in his lodgings every day until he was cured..$^{75}$ The ambassador makes

73 "[Q]uando vino el embaxador del turco, se le pusso guardia, con pretexto de cortejo, y que fue para embarazar e impedir algunas ofensas de Dios en la gente de la corte, y que ahora respectiuamente, aunque no en forma de guardia (por ser este embiado y el otro embaxador), se le deuerán poner personas que eviten el mismo embarazo, y aun con más cuidado y maña, porque se dize que aun no fue bastante el que se puso por lo passado para estorvarle": Espadas Burgos, "Andanzas," 83-87.

74 García Mercadal, Viajeros, 307-08, 310, 323, 326. Al-Bustani chose not to translate those interjections and the severest criticisms of the monarchy and the Church, though he acknowledged the omissions: al-Gassani, El viaje, 48-49.

García Mercadal, Viajeros, 316. 
several other critical remarks about the Church $^{76}$ and Spanish society as a whole. ${ }^{77}$

The Moroccan provides details of his first meeting with Charles II. He was asked about "our manner of greeting," since the king "had never received persons of our religion," and replied that for people of other faiths the proper form was, "Peace to those who follow the true path!". He reports with a certain pride that the king seemed surprised but "had no choice but to accept it, because he knew we had decided to add nothing more." 78 But these recollections contrast with how Charles II actually received him in Aranjuez. After greeting the ambassador Charles took the letter from Muley Ismail, kissed it, and doffed his hat out of respect on speaking the name of the Moroccan sovereign. ${ }^{79} \mathrm{He}$ handed al-Gassani a return letter to Muley Ismail, "kissing it and giving it to us after inquiring after our health," then said:

Convey to His Sharifian Majesty the proper greetings from us. We beg him to treat kindly our captives whom he holds in his lands. All that His Majesty desires of us we shall do speedily, out of respect for his rank.

When the king asked al-Gassani if he could grant him a wish, the Moroccan replied, "We made clear to him that we had no other wish than those proper to the exalted state of Islam." 80 Of course al-Gassani had to consider potential readers of his account, possibly the Alawite monarch and Moroccan notables, and make his words more severe on that account. We need further research to clarify whether the ambassador's opinions, and the nature of his reception

76 In one instance he reacted to a sermon saying, "What impieties the priest told - may God free us from them!". On the belief in miracles: "the devil makes them see these imaginary things": al-Gassani, El viaje, 62, 81-82, 86. His criticisms of the Inquisition were milder: García Mercadal, Viajeros, 309-10, 327, 330-31. Al-Bustani, who made the first Spanish translation of al-Gassani's account, did not include the strongest passages against the Spaniards, evading them with phrases such as, "he writes notions that are severe toward them and toward the knowledge of the Christians." That translation was published during Spain's Protectorate in Morocco (1912-1956), when Francoist colonial authorities wanted to silence or soften criticism as much as possible.

77 He observed shrewdly that Spaniards did not like to trade or travel for business, or work in "base" occupations, preferring to be bureaucrats or soldiers in hopes of joining the noble class: al-Gassani, El viaje, 46-47. He also thought that Spanish men should be more jealous of their wives: García Mercadal, Viajeros, 331.

78 Al-Gassani, El viaje, 43 .

79 García Mercadal, Viajeros, 304.

8o García Mercadal, Viajeros, 337. (In Bustani's version, "Present our greetings to the Sultan, and we hope for good treatment for the prisoners you hold"): al-Gassani, El viaje, 93. 
by Charles II, reflect unresolved tensions between the two monarchies and different ways of dealing with them on the two shores of the Mediterranean.

The next Muslim ambassador did not arrive in Spain until February 1701, when an envoy from the Dey of Algiers landed in Alicante to meet the newly crowned Philip Iv. ${ }^{81}$ The envoy was Mamete, "our captain of the sea and warfare," accompanied by Adahaman. ${ }^{82}$ By the Dey's express wish, a priest named Francisco de Ortega went with them from Algiers, "leading these Moors who come to kiss Your Majesty's hand, and as ambassadors to discuss certain affairs that may please and serve Your Majesty." 33

The Spanish monarch, on hearing of the arrival of an ambassador from "the one honored and praised among the Turks and Moors, Achi Amet Dey, king of Algiers, Tunis, and Tripoli," granted him a passport and ordered him supplied with everything he needed. ${ }^{84}$ The word went out to all the captains general, viceroys, governors, and other authorities who were coming

to conduct business with him, it being only just that to those who come from a prince of such fame and valor, all good welcome and honor should be done in our kingdoms and dominions. We have ordered and we command all our viceroys, lieutenants, captains general of the sea and the land, governors, and any other official persons, subjects, and vassals to grant free passage and transit to those who are sent by the king of $\mathrm{Al}$ giers and all their party and companions, so that nowhere shall they feel the slightest disturbance or vexation, but rather assistance and favor, under penalty of our displeasure, assuring those envoys that they shall be brought freely to our court. And after they have fulfilled their mission there they may return to their country without being detained

81 On this embassy see Windler, "La diplomacia," 224; La Véronne, "Un intento de alianza." I am grateful to Luis Fe Cantó for bringing documentation of it to my attention.

82 "Consultas originales y otros papeles sobre la venida del Embiado del Rey de Argel á esta Corte en el año de 1701": AHN, Estado, leg. 2866. The text mentions sometimes one ambassador or envoy and sometimes two; I have chosen to speak of one envoy with a companion.

83 Carlos Francisco del Castillo to Joseph Pérez de la Puente, Madrid, 5 April 1701: AHN, Estado, 2866.

84 "Passport signed by His Majesty for the two ambassadors who come from Algiers to this Court and are now in Alicante. To be forwarded to the Viceroy of Valencia with a dispatch of the same." It is also noted, "I do not know if this Deu [sic] of Algiers is the same one who came the other time": Buen Retiro, 7 March 1701. The notice goes to the Viceroy of Valencia to ensure "the safety of the voyage to this court of the Ambassadors from Algiers who have landed at Alicante": Buen Retiro, 16 March 1701, AHN, Estado, 2866. 
or mistreated anywhere in our kingdoms and dominions. For which we order the dispatch of this letter, signed by our royal hand, sealed with our private seal, and approved by our Council of State, named below. ${ }^{85}$

The governor of Alicante was instructed to provide a proper escort and keep the court informed of the arrival of

two ambassadors from the Regency of Algiers, whose legal documents have been determined: a passport they carry from the king my uncle ... and certification of having passed the quarantine in Majorca, with the provisional information you gave to that governor. We order that if these Moors have fulfilled their quarantine you permit them to come to this Court, and we advise that if you deem it necessary to send with them some soldier or minister to guide and defend them against the insults of the ignorant populace, you should do so. And to make their journey more secure I have ordered them sent the attached passport, which is conveyed to you to give to them. ${ }^{86}$

85 “... [P] ara tratar algunos negocios de su parte, y siendo justo que a los que vinieren de la de un Principe de tanta fama y valor se le haga en nuestros Reynos y Dominios toda buena acogida y agasajo; hemos ordenado y mandamos á todos nuestros Virreyes, Lugarthenientes, Capitanes Generales de Mar y Tierra Governadores y qualesquiera otras personas oficiales, súbditos y vasallos, concedan libre pasage y transito á los que vinieren embiados de parte de dicho Rey de Argel, y á toda su comitiva y acompañamiento, sin que en ninguna parte experimenten la menor molestia ni vexacion, antes bien toda ayuda y favor, so pena de incurrir en nuestra desgracia, asegurando á las dichas personas que vinieren embiadas que serán conducidas á esta nra. Corte, con toda libertad; y que después de haver cumplido en ella la comisión que trahen, podrán bolberse á su Patria, sin que en ninguna parte de nuestros Reynos y Dominios se les haga detención ni mala obra; para cuyo efecto hemos mandado despachar la presente firmada de nuestra real mano sellada con nuestro sello secreto y refrendada de nuestro infraescrito Consejo de estado": Draft dated at Buen Retiro, 15 May 1701, AHN, Estado, 2866.

86 “... [D]os embaxadores de la Regencia de Argel de lo que havia investigado acerca de su legacía: pasaporte que trahen del Rey mi tio ... y certificación de haver hecho la quarentena en Mallorca; como de lo que provisionalmente previnisteis á aquel Governador; ha parecido ordenamos que si estos Moros huvieren cumplido ya con su quarentena los dexeis venir a esta Corte; y advirtiendoos que si juzgaseis necesario embiar con ellos algun cabo ó Ministro que los dirija y defienda de los insultos de la plebe ignorante, lo executeis assi; y para mayor seguridad de su viage he mandado despacharles el pasaporte adjunto que se os envía para que se le entreguéis": Inquiry to Marquis of Villagarcía (who had sent two earlier letters, 15 and 23 February), dated 7 March 1701. Letter from Marquis of Villagarcía to Josep Pérez de la Puente, Valencia, 22 March 1701. Letter from the Council of State, Madrid, 7 April 1701: AHN, Estado, 2866. 
The head of the Algerians' escort, Carlos Francisco de Castillo, asked for instructions about their treatment and was told to proceed "just as was done with the envoy of the king of Meknes who came to this Court in 169o, as to the audience he obtained and the manner of attending and lodging him, even though that case did not conform to the present one." But there was uncertainty about the true nature of the delegation, because

the one they call the King of Algiers is not a sovereign, while the one from Meknes is, and wields great power; so for any determination that is proposed to you we need to know what status these Moors bring, for according to it we should moderate the demonstrations of welcome that are made to them.

In spite of these doubts the Council of State was in favor of receiving the envoy, since he was clearly an ally against the ruler of Morocco:

As for the king or viceroy of Algiers, enemy of the king of Meknes - whose strength we need to counteract by every means possible - you may order that wherever they go these men may be given a balcony for viewing the bullfight, and a coach from the stables in which the coachman gives the best seat to the principal [envoy], treating them with all urbanity and benevolence and protecting them from any insult from the people, so that they may be grateful for their welcome. ${ }^{87}$

In April the Council of State was much concerned to decide if the envoys "must be given a balcony at the next bullfight." But the larger question was whether the Algerians actually deserved the status of ambassadors. Francisco de Castillo confessed that he could not determine what rank the men held:

87 “... [E]l que llaman Rey de Argel no es Soberano y el de Mequinez si y con gran poder, con que para qualquiera resolución que se hubiese de proponer á V.M. hacia mucha falta saberse que carácter trahian estos Moros pues según el se deberían medir las demonstraciones de agasajo que se hiciese con ellos. ... Al Rey o virrey de Argel enemigo del de Mequinez, cuyas fuerzas necesitamos contrapesar por todos los medios posibles, puede V.M. servirse mandar que por donde toca se dé balcón para fiesta de Toros a estos hombres, y coche de la Cavalleriza en que el conductor dé el mejor lugar al principal, usando con ellos de toda urbanidad y benevolencia resguardándolos de todo insulto del Pueblo, de suerte que queden obligados al agasajo": Consejo de Estado, Madrid, 2 April 1701, Estado, 2866. 
Having been with them he found no proof of the status they bring, since they claim not to have a copy of the accrediting letter and that they cannot open the original until they place it in Your Majesty's royal hands. ${ }^{88}$

Once the group reached Madrid the Algerians were housed in the monastery of the Santísima Trinidad. No one knew how to address them, since their rank was still unknown:

Since the Secretariat finds no example regarding this Divan or Viceroy of Algiers, whether any envoy has ever come in his name, it reports that when an envoy from the king of Meknes came to this Court at the end of 1690 he was lodged at the visitors' lodgings, just as was done in ' 73 for another envoy from Muscovy. And his host was ordered to treat him like any royal envoy, and attend him with all correctness: the host should go out to meet him and give him the best seat in the carriage and address him as "Señor," with all the other practices that are usual with other envoys and a little more distinction. If the envoy eats in our manner at a high table [the host] should attend him, taking the next place ... .The Council later discovered ... the notice of how the Turkish ambassador who came to this court was received in the year 629 [sic], and comparing the circumstances of the two cases it was resolved to order the host to act in that encounter as was recorded in the report (of which he was sent a copy signed by the Secretary of the Bureau). Its import is that His Majesty having decided to receive him as he receives other envoys from kings and emperors out of the esteem in which he holds his master, and because he is very pleased with his purpose of negotiating freedom for the captives, coaches will be sent from His Majesty's stables for him and his family. ${ }^{89}$

88 "Hauiendo estado con ellos no encontró razón del carácter que trahen, diciendo se allauan sin copia de la carta de creencia, y que la original no podían abrirla hasta ponerla en las Reales manos de V. Magd": Consejo de Estado, Madrid, 2 April 1701, AHN, Estado, 2866.

89 "La Secretaria no hallando exemplar en termino deste Diuan o Virrey de Argel, en cuyo nombre aya venido algun embiado suyo, hizo presente que haviendo venido a esta Corte un embiado del Rey de Mequinez por fines del año 169o se le mando hospedar en la casa de los hospedajes, en la misma forma que el año de 73 a otro embiado de Moscovia, y al conductor se ordeno le tratase como a qualquier embiado de Corona, y que en la forma de asistirle se executase toda puntualidad; que el conductor le saliese a reziuir y en el coche le diese el mejor lugar, y el tratamiento de señoria, con todas las demas circunstancias que solia practicar con los demas embiados y con alguna especialidad mas; que si el embiado comiese a nuestro usso, y en messa alta le asistiese tomando el Lugar después del.... Que después se reconozio en el consejo ... la etiqueta de la forma en que fue rezibido el año de 629 el embaxador del Turco que vino a esta corte; y cotejadas las circunstancias de 
It was decided to offer "resources appropriate to his maintenance, and a place for them to attend the festivities." But the Council insisted that the degree of ceremony offered to the Moroccan ambassador was not the right model, because unlike the monarch of Morocco the Dey of Algiers was not a sovereign. It added that the Algerians had not described the exact nature of their embassy. Francisco de Castillo replied that the North Africans persisted in calling themselves ambassadors but would not show the credential that proved it..$^{90}$ Besides, they were asking for the earliest possible audience; they had been given only three months to carry out their mission and would be punished if they took any longer. ${ }^{91}$

All these doubts about what was due to the ambassador show that little was known about how the Regency of Algiers was governed. One of the Council's requests for clarification stated:

Don Andrés de San Juan will tell me the significance, meaning, or reason of the word "Day" among the Moors. As for the notion that he who governs Algiers as Day is King of Algiers, this is not a king but one who is elected. This word "Day" is the surname of all those chosen by the army to govern Algiers - they call the Day King of Algiers but in reality he cannot be called a king; the army may depose him and kill him and put another in his place, of which there are many examples. And in a letter we find from a predecessor he begins by calling himself "Hazan Day," meaning Hazan (his name) and Day (the common surname of these elected figures). And in another a different predecessor styles himself Governor of Algiers. We do not know how the letter written now from Algiers will be, but the ones His Majesty has already answered say "Day, King of Algiers." ${ }^{22}$

uno, y otro casso, se resolvió ordenar al conductor que en aquella Audiencia executase lo que se prevenia en memoria (que se le remitió copia original baxo firmada del Secretario del Despacho) cuya sustancia en que S.M. havia determinado rezibirlo, como rezibe a otros embiados de Reyes, y emperadores, por la estima que hazia de su Amo, y por serle muy grato el negocio que venia a tratar de la livertad de los cautivos; que se le embiarian coches de la Cavalleriza de S.M. para el y su familia": the Council to Francisco del Castillo, 9 April 1701, AHN, Estado, 2866.

90 Carlos Francisco de Castillo to Joseph Pérez de la Puente, Madrid, 5 April 1701. Two drafts of notes from the Council of State declared the same thing: Madrid, 7 April 1701. The Council to Francisco de Castillo, 9 April 1701, AHN, Estado, 2866.

91 Francisco de Castillo tells of being prostrate in bed after two bloodlettings: Carlos Francisco del Castillo to Joseph Pérez de la Puente, Madrid, 11 April 1701. Consultation of the Council, 11 April 1701, AHN, Estado, 2866.

92 "Don Andres de San Juan me pondrá aquí la significación sentido o razon tiene la palabra Day entre los Moros; respecto a que sepase el que Govierna a Argel Day Rey de Arxel, esto no es Rey sino elexido-- esta palabra Day es apellido de todos los que elixe la Milicia para 
A report from Francisco de Castillo, who acted as host to the ambassador, was also debated:

He is carrying out the order he was given to inquire about the status of these Moors who have arrived from Algiers, and they answered that they have the rank of ambassadors, as is declared in their original letter of accreditation, which they will place in Your Majesty's hands. In the official passport they bring they are sometimes called "ambassadors" and sometimes "envoys"; and the priest who comes with them assures me that when the King of Algiers gave him his orders he asked him to come with the "ambassadors" he was sending to the King of Spain; and these Moors ask most urgently to be granted an audience as soon as possible .... The Council assures Your Majesty that the motives for welcoming this Moor and treating him well are those set down for Your Majesty in the attached consultations of the 7 th of this month, and that the relevant points are: first, the audience they seek from Your Majesty; and the Council thinks that there is no time for it among the events of this week, but that after these pending affairs are concluded Your Majesty may console them by receiving this Moor as an envoy extraordinary. ${ }^{93}$

el Goberno de Arjel-- al qual llaman day Rey de Arjel pero realmte. No se puede llamar rey respecto de que le quita y le mata la miliscia poniendo otro en su lugar de que hay muchos exemplares-- y en una carta que se halla de otro antecesor empieza nombrándose hazan Day que quiere decir hazan su nombre y Day es el apellido común de estos elexidos-- y en otra se pone otro antesesor Gobernador de arjel, pero no se sabe como vendrá la Carta que se escribe a ora de Arjel, pero en las que se han respondido por su Magd se le han puesto Day Rey de Arjel": "Vease en el consejo. Del Conductor de embaxadores recibo el papel incluso y pongo en las reales manos de V.M.”: 11 April 1701, AHN, Estado, 2866.

"[Q]ue satisfaze a la orden que se le dio para que inquiriese el carácter con que venían despachados los Moros, que han llegado de Argel; diciendo le han respondido que su carácter es de embaxadores, y que se halla declarado en la carta de crehencia original, que han de poner en las manos de V.Mgd.; que en la refrendada de Pasaporte que traen, en unas partes se les nombra embaxadores y en otras embiados; que el Religioso que viene con ellos asegura que el Rey de Argel, quando le encargo su asistencia, fue pidiéndole que viniese con los embaxadores que enviaua al Rey de España; que estos Moros solicitan con vivas ansias que quanto antes se les conzeda audiencia. ... El Consexo representa á V.Magd. que los motivos que ay para agasaxar y tratar bien á este Moro, son los que se apuntaron a V.Mgd. en las consultas adjuntas de $7 \mathrm{y}$ del corriente que los puntos que ahora penden son, el primero la Audiencia que desean de V.Mgd. y esto pareze al Consexo que en las ocurrencias de esta semana no tendrá cavimiento, pero que pasadas las ocupaciones pendientes, podrá V.Mgd. seruirse de consolarlos reciuiendo á este Moro como embiado extraordinario." On the cover of the folder is written "Como parece y assi lo he mandado." José Pérez de la Puente to the Admiral of Castille, Count of Frigiliana, Count 
In the end the court decided to grant this envoy the same status accorded to the ambassador from Morocco in 1691:

The Secretariat reported that since it could find no example of this Duan or Viceroy of Algiers in whose name some envoy had come, it finds only that when an envoy from the king of Meknes arrived at this Court at the end of the year 690 he was ordered to be lodged in the visitors' lodgings in the same manner as an envoy from Meknes in the year 673 .

It was further proposed to respect "the form in which the ambassador from the Turk was received at Court in the year 649 [sic]" and that accorded to other ambassadors and envoys, because such a course suited the Spanish monarch's North African policy. ${ }^{94}$ Finally, the decision was made to grant the delegate an audience in a week's time and to address him as an envoy extraordinary. ${ }^{95}$

The envoy extraordinary, Mamete, had brought a letter in Arabic that, once received and translated, proved to contain two proposals. The first asked that Spanish troops in Oran remain neutral in the attack that Algiers was preparing against the Sultan of Morocco:

Our discourse leads to informing Your Majesty that with God's help, when spring comes, we shall ride out with all our army and ourself in person against Muley Ysmael, King of Meknes; asking that Your Majesty give a royal order to the Governor of Oran that he may know that we are in a state of friendship. And as to all the provisions that pass by sea or by land to Tlemcen, no harm be done to those who conduct them, much less to the couriers who travel for this purpose. Begging Your Majesty to give freedom to the three Moors who were seized last year in Oran as they

of Monterrey, Marquis of El Fresno, Count of Santistevan, and Count of Montijo, Madrid, 12 April 1701, AHN, Estado, 2866.

94 "Hizo al mismo tiempo presente la secretaria que no hallando exemplar en términos deste Duan, ó Virrey de Argel en cuyo nombre hubiese venido algun embiado suyo, solo se encontraba que haviendo llegado á esta Corte un embiado del Rey de Mequinez por fines del año de 69 o se le mandó hospedar en la Casa de los hospedages en la misma conformidad que el año de 673 á otro embiado de Mequinez." The allusion to 1673 appears mistaken. Response to the communication from Francisco de Castillo to José Pérez de la Puente, 19 April 1701. Council of State, Madrid, 23 April 1701. AHN, Estado, 2866.

95 Council of State to Francisco de Castillo, Madrid, 23 April 1701. The Council to the Viceroy of Valencia informing him of the Algerians' arrival at court, 27 April 1701. A summary of all that had been done, prepared for the members of the Council, dated 12 April 1701. A recommendation to Antonio de Ubilla to provide the Algerians with a coach and reimburse the Trinitarian monastery, Madrid, 28 April 1701. AHN, Estado, 2866. 
carried letters, for couriers are always free when they travel in service to the two dominions and to the proper guarding of Oran. It is very important to force the submission of this common enemy who disrupts and disturbs us, this being as much Your Majesty's duty as our own.

The crucial point was that the governor of Oran not hinder the movement of military supplies from Tunis to Tlemcen; the operation was directed against Muley Ismail, whose troops kept up a siege of Ceuta from 1694 to $1727 .{ }^{96}$ And the Dey of Algiers made a matter of mutual concern "the vigilance that should exist in Oran with this chance to make a vassal of the King of Meknes."97

The Algerians' second proposal was to reactivate the process of freeing Christian captives ("the ransoms can surely convert their alms into the rescue of captives"), which the Dey would guarantee:

The alms that were withheld in the time of our predecessors can, in our time, arrive with all assurances, since we offer our word and our faith that we will use them in all legality, as we promise in our safe-conduct; not desiring that the Fathers in charge of alms pay out any amount for the ransom of the Marquis of Barinas, because these alms should go to the most destitute slaves, and we know that everywhere in the world where alms are collected they are meant for the poor. This Marquis is a Spaniard, and if Your Majesty or one of his relatives wishes to ransom him by charity he

96 Guastavino Gallent, "Los comienzos del sitio"; Galindo y de Vera, Historia, vicisitudes.

97 "Encaminándose nuestro discurso a dar noticia a V.M. que con la aiuda de Dios quando llegue la primavera saldremos con todo nuestro exercito, y nos en persona, contra Muley Ysmael Rey de Mequines, solicitando que V.M. de su Real orden al Governador de Oran, para qe sepa que estamos amigos, y todas aquellas prevenciones, que pasasen asi por mar como por tierra, a Tremesen, no se les haga daño a las jentes que las condujesen ni menos a los Correos que pasazen para este fin - Suplicando a V.M. mande dar libertad a los tres Moros que el año pasado cogieron en Oran que pasaban con cartas, pues los correos siempre son libres quando van en servicio de ambos dominios, y la buena vigilancia en Oran. Ymporta mucho para avasallar á este enemigo común que nos descompone y molesta, siendo esto tanto de la obligación de V.M. como de la nuestra": letter in the original Arabic with its Spanish translation, dated in the month of "Racheo" [Rajab], July-August 1700. The letter began: "Mostafa Day King of Algiers in our name, in that of our Pasha. Our Aga, Caya, Ascar and all the Great Mesulagas of our Kingdom salute the Magnificent and greatest of Kings, Lord King of all the Spains ... with a letter from the Governor of Algiers presented by his envoy Mamete, Captain" ("Mostafa Day Rey de Argel en nuestro nombre, en el de nuestro Bajá. Nuestro Aga, Caya, Ascar y todos los Mesulagas Grandes de nuestro Reyno; saludamos al Magnifico y mayor de los Reyes, el Señor Rey de las Españas. ... Con carta del Governador de Argel que ha presentado su embiado Mamete, Arraez"): Council of State, Madrid, 21 May 1701. AHN, Estado, 2866. 
may do so as he wishes; but as to any of the alms going to his freedom, we again give our word that we shall not permit it.

The letter also speaks of gifts being sent to the Spanish monarch:

In the battle I waged last month against the kings of Tunis and Tripoli - in which, with God's help, I defeated them utterly - I seized various spoils, and from the best of them I chose those I present to Your Majesty as a token of good understanding, promising that whatever Your Majesty and your government may require of us, a single word will be obeyed. ${ }^{98}$

The Minister of War, in the name of the Council, wrote to the Dey thanking him for his gesture; he also confirmed that the governor of Oran already followed a policy of not impeding the passage of Algerian troops and equipment toward Morocco. He added that the governor even had orders from the king to send him gunpowder:

He has no notice at all of the three Moorish couriers that are supposed to have been detained in Oran, since the Marquis of Casasola has given no information about this. And as to maintaining good intelligence with the Algerians, the fact is that since they asked the Marquis for his friendship, and security and good treatment for their troops and people who passed near Oran, and that they be helped with some quantity of powder, offering reciprocal attention and assistance whenever he wished to avail himself of it, Casasola has cultivated this good understanding with the governor of Algiers, without hindering the passage of his troops nor preventing the loyal Arabs of Oran from going to his aid, as has been

98 "Las limosnas que an estado detenidas en tiempo de nuestros antecessores, pueden en el nuestro venir con toda seguridad, ofreciendo nuestra palabra y fe, que obraremos con ellas con toda legalidad como lo aseguramos en nuestro salvoconducto no queriendo que los Padres de la limosna desembolsen caudal alguno, por el rescate del Marques de Barinas, porque la limosna debe dedicarse a los mas desvalidos esclavos, y sabemos que en todas las tierras del mundo quando se recoje limosna es para los pobres. Este Marquez es español, si V.M. ó algun pariente de el quisiere rescatarlo por caridad, puede executarlo como quisiere; mas que la limosna haya de dar por su libertad cosa alguna, damos segunda vez nuestra palabra de no permitirlo. ... [E]n la vatalla que e tenido el mes pasado con los Reyes de Tunez y de Tripoli, en la que con la ayuda del Gran Dios enteramente los derrote, tomé diferentes despojos, y de los mas escojidos junte los que presento a V.M. en señal de buena correspondencia, asegurando que aquello que V.M. y su govierno ubiere menester de nos con una palabra sola será obedecido": see letter in previous note, Council of State, Madrid, 21 May 1701, AHN, Estado, 2866. 
requested. There has been good passage and treatment for the Algerians, and he has promised that, having an order from Your Majesty, he would send him as much powder as he could; and on this point the Minister of War concludes that he is ordered to give whatever amount of powder they request, as long as it is not needed in that presidio, with the condition that on giving it he agree with them that he will receive the same favor if anything is needed in Oran. ${ }^{99}$

In the end the ambassador's presentation proved constrained, ${ }^{100}$ as we learn from the Council's report. By the king's desire

it is limited to celebrating Your Majesty's fortunate possession of your realms, assuring Your Majesty of [the Dey's] deep affection and happy mutual understanding, and presenting to Your Majesty as a token of it several spoils among the best that he obtained in the battles with the kings of Tunis and Tripoli. And as he prepares to campaign this spring against the king of Meknes, Your Majesty may assure the governor of Oran of his friendship so that he may do no harm to the people who convey his matériel of war.

"No tiene noticia alguna de los tres Moros Correos, que se supone haverse detenido en Oran, por no haber avisado el Marques de Casasola cosa particular en razón de esto. Y que en quanto á mantener buena inteligencia con los Argelinos, lo que ocurre es haberla solicitado estos con el Marques, pidiéndoles su amistad, y la seguridad y buen trato de sus Tropas, y gentes que pasasen por la cercanía de Orán, y que le socorriese con alguna cantidad de polvora ofreciendo hallaría la misma reciproca atención y asistencia con el, siempre que quisiese valerse de ella; que el de Casasola ha cultivado esta buena correspondencia con el Governador de Argel, sin embarazar el paso de sus Tropas ni impedir que le vayan a asistir los Alarbes de la devoción de Orán, que le ha pedido, habiendo todo buen pasage y tratamiento a los Argelinos, y prometido que teniendo orden de V.Mgad le embiaria la polvora qe pudiese; sobre cuyo punto concluye el Ministro de guerra le está ordenado entregue la cantidad de polvora que le pidieren como no haga falta en aquella Plaza, y con la advertencia de que al dar la dexe dispuesto con ellos el qe hallara igual correspondencia si se necesitase alguna cosa en Orán." Further, "The Council agrees with what the [Minister] of War proposes, adding that the governor of Oran should be asked for a report on the three Moorish couriers; and that a response be sent to this letter from the governor of Algiers presented by his envoy, expressing all gratitude and saying that we have asked for a report on the question of the Moors": Council of State, Madrid, 2 June 1701. AHN, Estado, 2866.

"Notice that should be given to the envoy from Algiers, by way of the ambassadors' host, of what practices should be observed in the audience": an undated document, but a note in the folder suggests that the audience would be held early in May. Note to the ambassadors' host, 23 April 1701, A HN, Estado, 2866. 
The Council repeated that it knew nothing of the three Algerian couriers that the Dey accused Oran of having detained, nor anything about contacts between the governor of Oran and Algiers. It did look favorably on offering Oran's help in "reducing the king of Meknes to vassalage" and on renewing the process of ransoming captives. ${ }^{101}$ There was discussion of whether the envoy should visit the various ministers of the Council of State, ${ }^{102}$ another sign of doubt about whether he held the rank of ambassador or not; only in the first case could he view the bullfight from a balcony, as he was eventually invited to do. ${ }^{103}$

The time came for the envoy to return home; he had landed in Alicante on 22 February and lodged in the Trinitarian monastery on 4 April. Francisco de Castillo considered it urgent to send the delegation home bearing the reply to the letter it had brought. Another important consideration was the gift that the envoy should be offered; Castillo thought he would depart feeling "very much scorned" if he were not given the same gift that the ambassador from Meknes had received:

He understands that the Moor sent from Algiers is waiting to be dismissed so that he may leave this Court, since his mission consists of no more that what is expressed in his letter of accreditation ... and that, if he is to be given a jewel such as Meknes's [ambassador] received, it may be planned in time to inform his host. ${ }^{104}$

The Secretariat of the Council of State reported that the envoy from Meknes in 1690 had received a magnificent jewel valued at four thousand ducats, "the same having been done with the [delegate] from the Grand Turk in the year

101 Council of State, Madrid, 21 May 1701, AHN, Estado, 2866.

102 Francisco de Castillo to Antonio Ubilla y Medina, Madrid, 18 May 17o1; Antonio de Ubilla to José Pérez de la Puente, 19 May 1701. Consultation of the Council of State, Madrid, 21 and 26 May 1701, AHN, Estado, 2866.

103 A balcony for the bullfight and a coach from the royal stables: Council of State, Madrid, 9 April 1701. Order by Antonio de Ubilla on the same subject, 9 April 1701. Carlos Francisco de Castillo to Antonio de Ubilla on the same subject. Council of State to Francisco de Castillo, Madrid, 12 April 1701, AHN, Estado, 2866.

104 "[T]iene entendido que el Moro embiado de Argel aguarda á que se le despache para partir desta Corte, respecto de que su negociado no consta mas que de lo mismo que expresa la Carta de creencia ... y porque en caso que se le haya de dar joya como al de Mequinez se pueda prevenir con tiempo lo participe al Conductor." This makes clear that the envoy knew about the earlier embassy, an important point in the context of Spanish-North African relations. Carlos Francisco de Castillo to Antonio de Ubilla y Medina, Madrid, 28 May 1701, AHN, Estado, 2866. 
650." But it pointed out that the Algerian case "seemed to be different," proposing that he be given a jewel "but not of the same value and price of that one [to the envoy from Meknes], rather it should be of the quantity that you desire, in view of the state of the royal treasury."105 In the end the Algerian envoy left the court on 20 June for Alicante, where he would embark. ${ }^{106}$

As had happened on other occasions, the Algerians' stay in Madrid caused enormous interest among its residents - which could even result in tragedy, as Francisco de Castillo stated in his report on the expenses and inconveniences that the Trinitarians had suffered while hosting the visitors ("in hopes of gaining some relief for our captives in Algiers"). To avoid unpleasant incidents, the public was barred from entering the monastery:

[The host] must not allow any sort of persons, Moors or Christians, to enter the Moor's lodgings, except those designated to attend him - even in the role of interpreter or on any other pretext. Nor may he permit persons calling themselves servants of Your Majesty to attend his meals, to avoid any inconvenience. And he must take special care that no women enter the lodging, even if they claim a whim of pregnancy; for that purpose the host may allow the envoy to show himself on a balcony of the lodging where they can see him from the street. ${ }^{107}$

An additional danger was the animals that came with the Algerians as gifts for the king: there were two horses that had been seized from the Tunisians, two lions, and a serval, a kind of wild cat. ${ }^{108}$ The "Minister and Friar of the Most Holy Trinity [monastery]" warned of the danger the animals represented:

105 Carlos Francisco de Castillo to José Pérez de la Puente, 27 May 1701. Council of State, Madrid, 28 May 1701 and 2 and 7 June 1701, AHN, Estado, 2866.

106 He was escorted as far as the Puente de Toledo at the edge of Madrid, as had been done for the ambassador from Meknes before him: Carlos Francisco de Castillo to José Pérez de la Puente, 21 June 1701. AHN, Estado, 2866.

107 "Que no consintiese que entrasen en la posada del Moro, ningun genero de personas, ya Moros, o ya christianos, excepto los destinados para asistirle, aunque fuese a titulo de Ynterprete ó con otro qualquier pretexto, ni permitiese que a la comida se introduxesen ningunos sujetos a titulo de criados de V.Mgd. por evitar inconvenientes. Y que cuidase mucho que ningunas Mugeres entrasen en la posada aunque fuese con antojo de preñadas, para lo qual dispondrá el conductor que el embiado se dexase ver en algun Balcon de la posada, a donde le pudiesen ver desde la calle": Council of State, Madrid, 7 April 1701, AHN, Estado, 2866.

108 There were also embroidered bags, three flasks (one meant for powder), and "a closed box that they say contains items from their country"): Consultation, 11 April 1701. The host, Carlos Francisco de Castillo, to Joseph Pérez de la Puente, Madrid, 11 April 1701, AHN, Estado, 2866. 
He considers the disturbance that comes from lodging them, both for the multitude of people who come to see them out of curiosity, and for the unfortunate incidents they fear from the lions they have brought, for although they are tame the noise of the people makes them fierce. Nonetheless the Minister offers to keep [the visitors] (as long as the animals are moved elsewhere) and be compensated for the cost of their food, which will be much less than in any other lodging, and nowhere else will they be better off .... And the second point the Council must ponder is to help the friars and give them food while [the visitors] are in that monastery, and also to console those pious men by removing the wild animals that make so much noise. ${ }^{109}$

He also condemned the curious people who came to see the envoys:

So thoughtless are the people that infinite numbers, curious to see them, come in such disorderly crowds that a while ago they pushed down the door of the cell where they are living. And aside from this inconvenience they fear they cannot avoid many other misfortunes, because although the lions are tame the noise of the people who come makes them fierce; and there are no cages to keep them in, only an open room with the sole precaution of a chain fastened to a very fragile wooden pillar, so with just a little strength they can pull free. ${ }^{110}$

109 "[P]ondera la molestia que se les sigue de su hospedaje, assi por la multitud de pueblo que llevada de la curiosidad acuden a verlos, como por las desgracias que rezelan de los leones que traen, pues aunque vienen domesticados, los embravece el ruido de la gente; que no obstante ofrece el Ministro mantenerlos (como se les muden las fieras a otra parte) y se les recompense el gasto de su alimento, que será mucho menos que en otro qualquiera hospedaxe, asegurando que en ninguno estarán ellos mas vien hallados. [...] Y el segundo punto considera el Consexo, es socorrer á los frailes, para que los den de comer, mientras los tuvieren en aquella clausura, y consolar también á aquellos Religiosos sacando de allí las fieras que tanto ruido les dan." On the reverse of the document is a note, "As it seems and so I have ordered": Joseph Pérez de la Puente to the Council of State, Madrid, 12 April 1701, AHN, Estado, 2866.

110 "[E]s tal la ligereza del Pueblo que acude infinita Jente a la curiosidad de verlos en tan desordenado tropel que poco ha derrivaron la puerta de la celda que havitan i no solo se sigue este inconveniente sino el de muchas desgracias que rezelan no podrán evitar porque aunque los leones vienen domesticados el Ruido de la Jente que concurre los embraveze i no teniendo jaulas en que enzerrarlos sino solo un aposento abierto sin mas resguardo que el de una cadena assida a un pilar de madera mui débil con poca fuerza se pueden arrancar": Carlos Francisco de Castillo to José Pérez de la Puente, Madrid, 11 April 1701. Consultation with the Council, Madrid, 11 April 1701, AHN, Estado, 2866. 
The king agreed to help the Trinitarians, have the animals moved to a safer place, ${ }^{111}$ and reimburse the monastery. ${ }^{112}$

A less-known visit was that of the Bey of Tlemcen, who landed at Palma de Mallorca in 1761. It is not known whether he completed a diplomatic mission or not:

Yesterday the Spanish ship of the line El Firme, of seventy guns, arrived. On board were Monsieur Bignon, Provost and Master of Ceremonies of the Order of the Holy Spirit, who was returning from Madrid after having invested the Prince of Asturias and was going on to Naples to bestow the same honors on the King of the Two Sicilies. Also traveling were the Papal Nuncio and the Bey of Tlemcen. The latter showed himself unimpressed by the notable aspects of the town; they dined in the palace, where the Bey prayed in the garden for three-quarters of an hour (he did not want to pray in any of the rooms because there were holy images in all the ones offered to him).113

All these events confirm the importance of the ambassadors and envoys from Muslim lands who arrived in Spain throughout the Early Modern period. They were especially numerous in the first half of the sixteenth century, but they left their imprint on the imperial court at other times as well. The narratives we quote in these pages are incomplete, and new research will reveal many more instances than these. They are one more example of how badly we need to revise the history that insists on a dominant spirit of crusade and the concept of the "forgotten frontier."

111 Council of State to Francisco de Castillo, Madrid, 23 and 28 April 1701, and Madrid, 28 April 1701, AHN, Estado, 2866.

112 José Pérez de la Puente to the Council of State, Madrid, 12 April 1701, AHn, Estado, 2866.

113 "Ayer llegó el navío español El Firme, de 70 cañones. Iban a su bordo Mr. Bignon, Preboste y Maestro de Ceremonias de la Órden del Espiritu Santo, que regresaba de Madrid después de haber investido al Principe de Asturias, y pasaba á Nápoles para entregar iguales insignias al Rey de las Dos Sicilias. Viajaban tambien un Nuncio Pontificio y el Bey de Tremezen; éste último se manifestó muy poco impresionado por las cosas notables de la población: comieron en Palacio, donde el Bey oró durante tres cuartos de hora en el jardín, para no hacerlo en ninguna habitación, por haber imágenes en todas las que se ofrecieron." The ship arrived and departed on the same day, 19 August 1761: Campaner Fuertes, Cronicón Mayoricense, 549. 
In the Early Modern age, what we might call Spain's "internal colony" of Muslims had three basic components, in addition to slaves: non-baptized freedmen, Muslims who arrived freely from North Africa and the East, and Moriscos who returned to their Islamic faith. It is not always easy to distinguish among them because contemporary documents do not classify them precisely, making it very hard to discern their status or condition - in particular, whether we are dealing with slaves, free persons, or baptized or non-baptized freedmen, while the Moriscos present their own special problems. Though they were all subject to severe control by the state they were certainly able to act with some spirit of community. There is a parallel with the medieval aljamas, neighborhoods reserved for Muslims or Jews, since this population was never fully integrated into the society of the Spanish Empire.

It is clear, in any event, that Muslims were always able to reside in Spain as free persons - for longer or shorter periods, temporarily or permanently from the sixteenth to the eighteenth centuries. It is important to note that free Muslims occupied a space of relative liberty that slaves could share to some extent: there was a category of cortados, slaves whom their owners hired out for other work and who were almost always saving to buy their freedom. Therefore everything we say in this section about free Muslims may be applied to slaves as well, so we will speak without distinction of one group and the other.

After the Christians conquered the kingdoms of Castile and Aragon, resident Muslims were allowed to remain there as free persons. ${ }^{114}$ Later, after the Nasrid kingdom of Granada fell in 1492, its Muslims who wished to remain were able to do so. Because the capitulations the Catholic Monarchs offered to the last Nasrid ruler, Boabdil, recognized religious freedom, Muslims kept their mosques (though some of the larger ones were confiscated) and their cemeteries. ${ }^{115}$ But little by little and with growing intensity, pressure grew on the Muslims to convert to Christianity, after which they were called Moriscos. The first reaction was the revolt of the Albaicín neighborhood of Granada, which expanded to a large swath of the former Nasrid kingdom. It was easily put down, after which the most fervent Christians persuaded the monarchs to pass the Royal Ordinance of 1502: it decreed the Muslims' forced baptism, on pain of expulsion - a deliberate repudiation of the Capitulations of 1492. In the

\footnotetext{
114 Echevarría Arsuaga, La minoría islámica.

115 On the Mudejar cemetery in Valladolid in 1491 see Gómez Renau, Comunidades marginales en Valladolid, 58. On Muslim cemeteries in general see Casal García, Los cementerios musulmanes de "Qurtuba.” Torres Balbás, Ciudades hispano-musulmanas, 1:239-66.
} 
same year all the Muslims of Castile were made to convert, and similar orders followed for those of Navarre in 1515-1516 and those of Aragon in 1526. ${ }^{116}$ The period in which Spanish Muslims could continue their religious practices in their places of worship extended, then, from 1492 to 1526, but in a territory that grew ever smaller.

We know much less, however, about North Africans who traveled to or lived in Spain in the sixteenth century. We do know that some of them exercised their professions freely during that time. Doubtless they arrived in flight from famines in the Maghreb in the early 1500 s and from the struggles for power among North African rulers, as we saw in Chapter 2. A Moroccan physician, Ahmed Jerife, exiled to Spain after the Battle of the Three Kings, practiced medicine in Castile and Andalusia between 1580 and 1590 and never converted. In 1593 an Algerian named Andrés Manuel de Olivares, who must have been a convert, requested a license to practice surgery in Madrid. ${ }^{117}$

We must add to these few examples the Muslims who came to Spain in the retinues of ambassadors, envoys, and exiles and then decided to stay, converting or not, as we saw in Chapters 2 and 3. The bulk of free Muslims were traders, and in view of their importance we will deal with them in a separate section of this chapter. A considerable number of Muslims, in short, passed through Spain - with or without a safe-conduct - or decided to remain there permanently.

Finally, there were Muslims slaves who gained their freedom through manumission, their former masters' wills, or self-purchase. ${ }^{118}$ Historians have thought of them as a small group, whether in absolute terms or as a proportion of all enslaved Muslims. ${ }^{119}$ Though indeed their numbers are low they are almost certainly larger than has generally been admitted, ${ }^{120}$ and some of those freed persons, whether converted or not, elected to remain in Spain.

In eighteenth-century Cádiz ninety-one free Muslims have been identified, sixty-five Turks and twenty-six Moors. Among them were an Algerian named

116 Domínguez Ortiz and Vincent, Historia de los moriscos, 17-28; Vincent, "Convivencia difícil."

117 Tarruell, "Circulations," 185-86.

118 Cortés Alonso, "La liberación del esclavo."

119 Martín Casares, in his study of slavery in sixteenth-century Granada, titles his chapter on manumission "El porcentaje de liberaciones era mínimo" ("The percentage of manumissions was minimal"): La esclavitud en el Reino de Granada. Sánchez-Montes González believes the same about the seventeenth century: La población granadina, 130.

120 Very few studies try to count the number of manumissions, and normally the origin of those freed is not known. In most cases it is impossible to know how many of them were Muslim. 
Hassan (1730) and a Moor named Ali (1743), who must have been unbaptized because they kept their Islamic names. Another, Murat, presumably was not baptized either but his daughter was; born in Sardin (in Turkey), she was named Teresa Gaenta. ${ }^{121}$ Such opposite choices must have been common in families of slaves. In Málaga one hundred eight individuals were freed by manumission and eighty-four through their owners' wills between 1487 and 1538 . We do not know how many continued as Muslims, but the names Mahomad Ali, Hamete, and Fatima suggest that these were not converts. ${ }^{122}$ We have documentation for some other cities and towns in Andalusia: Córdoba, ${ }^{123}$ Jaén, ${ }^{124}$ Huelva, Palos and Moguer, ${ }^{125}$ and Ayamonte. ${ }^{126}$

In Murcia in 1690 twenty-one out of a total of forty-four Muslims were freed, though we do not know how many professed Islam. ${ }^{127}$ Information from Cartagena is sparse. ${ }^{128}$ In Madrid we know of only a few who obtained

121 Parrilla Ortiz, La esclavitud en Cádiz, 58-59, 130, 137.

122 The 108 manumission letters and 84 wills are recorded, but we do not know how many Muslims were the beneficiaries. The names we know are Mahomad Ali, Hamete, Fatima, the North Africans Francisco de Melilla, Francisco de Córdoba, and Fernando de Trípoli, the white man Diego, and the Moors Juan, Beatriz, Pedro Moreno, Inés de Castro, Elvira, and Catalina: González Arévalo, La esclavitud en Málaga, 386-87, 392, 397-400.

123 In 1574 Hernán and Lucía Rodríguez arranged to buy their own daughter's freedom. The Morisco Luis de Argote was manumitted in 1580: Aranda Doncel, "La esclavitud en Córdoba," 169 .

124 A Morisca was set free in 1578: Aranda Doncel, "Los esclavos en Jaén," 251. Francisco de la Cruz, a North African, received a manumission letter from his mistress in 1685: "He came as a Moor, un-Christianized, and while in her service and that of her husband and children he accepted our holy Catholic faith": López Molina, Una década, 112-13.

125 Of the freed slaves in these three cities four percent were Muslim. Juan, a North African captured in 1562, was set free when he voluntarily accepted baptism. Agustín, a North African, bought his freedom in 1581. Julián Prieto was freed in 1637 because "he was born and brought up in my house" and was about to be married. The Moorish woman María Oliva and her sons Juan and Alonso Galindo were manumitted in 1658. The North African Agustín Thomás bought his liberty in 1685 . Catalina de Mesa, "of the Turkish nation," gained her freedom in 1695: Izquierdo Labrado, La esclavitud en la Baja Andalucía, 2:87, $89,92,128,143,177$.

126 Zalem Bensai, aged seventy, bought his freedom from his master for seven hundred reales in 1642. Pedro, a North African, was freed by his master in 1662 on condition that he continue as a slave in one of the city's monasteries for two years: González Díaz, La esclavitud en Ayamonte, 149, 151.

127 A survey in 169 o identified forty-four Muslims: twenty-three slaves and twenty-one freed persons, most of them (thirty-four) Algerians and Moroccans. Another eight were born in Murcia: Vincent, "Musulmanes y conversión," 79-80.

128 In June $175^{2}$ the governing body of the charity hospital in Cartagena granted a request by Amet, a slave at the institution, to gain his freedom by paying his ransom: Martínez Rizo, Fechas y fechos, 1:260. 
their freedom. ${ }^{129}$ In several places in Extremadura at least thirty-eight Morisco slaves were freed between 1574 and 1606; of these twenty-three paid their own purchase price. ${ }^{130}$ There are documented manumissions of Moriscos, North Africans, and Turks in several towns in the region: Badajoz, ${ }^{131}$ Cáceres, ${ }^{132} \mathrm{Za}-$ fra, ${ }^{133}$ and Llerena. ${ }^{134}$ We also have records from Valladolid ${ }^{135}$ and Majorca. ${ }^{136}$

Not every slave who requested manumission achieved it, nor could every one afford to buy it. ${ }^{137}$ Some were accused of having forged their letters of manumission. ${ }^{138}$ Since some of these freed slaves returned to their countries

129 They included Ana de Saint-Raymond and María de San Antonio, both of Turkish origin, in 1689. In the eighteenth century Ana, also Turkish, was declared free; in 1702 a young Turkish man was freed; in 1741 María Juana Catalina de la Cruz, formerly Yamina Ochafament, was manumitted: Larquié, "Captifs chrétiens...Une lecture comparative," 392, 394, 401-02, and "Captifs chrétiens...Un tentative."

130 Periáñez Gómez, Negros, mulatos, 487.

131 Manumission of Úrsula de Villarreal, a Morisca slave born in Granada, in Badajoz on 9 August 1595: Cortés Cortés, Esclavos en la Extremadura, 52, 102.

132 Alonso de la Fuente, a Morisco, was freed by his owner in 1582 though he had to pay sixty ducats. Manuel, "of the Turkish nation," achieved freedom by converting but had to pay his owner 1,50o reales in 1587: Periáñez Gómez, Negros, mulatos, 479, 484, 49o.

133 The Morisca María de Córdoba was manumitted in 1579; Águeda de Cárdenas and Isabel de Guzmán in 1587; María Gracia in 1681, "because being Moorish she turned Christian." Several Moriscos from Zafra collected money to free Pedro, a slave who was "branded on his face": Periáñez Gómez, Negros, 479, 492.

134 The Turkish slave Mahoma gained his freedom in 1598 "to be able to go to Constantinople and other places that he wishes." Inés, a Morisca slave from Llerena, received permission to travel to other towns to borrow from her relatives in order to ransom herself: Periáñez Gómez, Negros, 479, 482, 492, and "La liberación de los esclavos de Llerena."

135 In 155 o the Turkish slave Casarrami gained his freedom through ransom and because "he wishes to turn to our holy Catholic faith." María de la Concepción, a Tunisian, was manumitted in 1554. Pedro Moreno, "an Arab from Bougie, a bozal [recently enslaved]," was freed in 1556 on condition that he serve his manumitter's son for eight more years. Francisca Mexía, a Morisca from Granada, bought her own freedom and her small daughter's in 1570. Alonso Hernández from Otura (Granada) bought his own liberty for one hundred ducats in 1587. In 1597 Francisco de Rojas, a Turk, obtained his freedom from his owner "because he became a Christian, he is sincere, and now Leonor de Jesús has asked him to be her husband": Fernández Martín, Comediantes, esclavos, 146-49.

${ }_{13}$ Freed Muslims who fell afoul of the Inquisition included Margarita in 1607, Isabel Pastor and Jerónimo Pastor, both North Africans, in 1629, Juan Bautista from Oran in 1686, and Juan José Cayetano from North Africa in 1788: Vaquer Bennassar, Captius i renegats, 127-30.

137 In 1575 Brianda, a Morisca slave in Villanueva de la Serena, sued her master to obtain her liberty: Periáñez Gómez, Negros, 433.

138 When some North Africans crossed from Castile into Portugal, the Portuguese Council of War had serious doubts about their manumission documents. In 1645 it wrote: "having understood that these Moors with their letters of liberation passed from Castile to this 
of origin, the number of free Muslims who had arrived as such in Spanish cities and ports and were not enslaved, together with those who had been freed, was small.

How, then, should we interpret the feeling, widespread among Christians in the sixteenth to the eighteenth centuries, that there were enough free and enslaved Muslims to constitute a threat? To answer this question we must add to free Muslims those slaves called cortados who, while lent out to work by their owners, enjoyed a good deal of autonomy and freedom of movement. There were also the Moriscos and their descendants who either had not abandoned Islam in their heart of hearts or actually tried to return to it, influenced and supported by free Muslim North Africans and Turks. While this group grew smaller with the passage of time, Old Christians long continued to think of them as a menace.

From the moment Granada was reconquered, Moriscos and Muslim slaves were seen as inevitable accomplices or collaborators of the North African corsairs who harried the Spanish coasts. In 1502 it was decreed that ransomed North African slaves could not live within fifteen leagues of the coastline, on penalty of one hundred lashes and consignment to the galleys if they disobeyed. The decree was renewed in 1530: "Let no freed North African slave be found within fifteen leagues of the seacoast." In 1566 Philip II expanded the order to the entire kingdom of Granada. ${ }^{139}$ The chronic corsair threat shadowed the popular image of the Moriscos, who were thought of as a fifth column that encouraged attacks by the powerful Ottoman corsair fleets, ${ }^{140}$ and as a consequence Muslims in general, and slaves in particular, were forbidden throughout the sixteenth century to live along the coast or in coastal cities. The pressure was so strong that the coasts experienced a relative decline in population - "relative" only because while isolated dwellings and fishing villages were abandoned, the population moved to fortified ports or places located at a prudent distance from the shore, preferably on an elevated and easily defended site. As a result, after the Alpujarras Rebellion (1568-1571) was crushed most of the defeated Moriscos were deported to the country's interior before being finally expelled in 16o9-1614.

kingdom ... [we propose] determining if the letters of liberation are genuine" and represented actual freedom and permission to travel to their own countries. In 1646 doubts arose about "the permission that Aly Amet and Amuda, Berbers, request to go to their own lands by virtue of the letters of liberation that their masters had given them": Archivo Nacional Torre do Tombo, cited in Cortés Cortés, Esclavos, 92.

139 Martínez Almira, "El intercambio de moros," 241.

140 Hess, "The Moriscos: An Ottoman Fifth Column." 
The forced exodus of almost all the Moriscos did not put an end to this problem. At about the same time several groups of Maghrebis sought refuge in Spain: more than forty landed in Almuñécar in 1605 and more than 210 arrived in Madrid in 16o9-1610. Not all of them converted; we will describe this situation in more detail in section 4.4. In the meantime Muslim slaves continued to be concentrated in the larger cities of the south and in Madrid, home to the court, adding to the impression of a Muslim menace. Nothing changed after the Moriscos' expulsion: between 1573 and 1712 about thirty royal and local decrees forbade Muslim slaves, and almost always free Muslims as well, from living less than twelve leagues from the coast. A decree of 1637 demanded levies of slaves to provide rowers for the galleys, but when their owners protested that they needed the income from hiring out their slaves, it was decided that Christian slaves - which essentially meant blacks - would not be included. Still, the bakers who made bread for the galleys in El Puerto de Santa María, most of whom were Muslim slaves, were also exempted. Two years later it was decided that every owner would pay a fee for each slave possessed. Between 1662 and 1667 it was ordered that Muslim slaves be sent to the galleys, particularly those in Málaga, but it seems that the measure was not carried out. ${ }^{141}$

In Cádiz in 1610 the city council proposed to the corregidor (crown magistrate) that because of the Muslim menace "free Muslims and slaves should be taken inland," but that does not seem to have taken place; in 1614 the licenciate Francisco Acevedo told the council about

the inconveniences that occur every day because there are so many of them and we have seen how they take boats and flee to Barbary, and since they are many we may fear some incident. Therefore you must take measures, as has been done in other places, for if enemies came to the city we would have to fear them [our Muslims] more than those from outside ... .They have been forbidden from walking in the street between the evening prayer and dawn, on pain of imprisonment. ${ }^{142}$

141 Domínguez Ortiz, "La esclavitud," 401-O2.

142 “...[L]os inconvenientes que cada día se iban sucediendo por haber cantidad de ellos y como se ha visto toman barcos y huyen a Berbería, y por ser muchos, se podía temer algún suceso. Por ello, tienen que tomar medidas como en otros lugares, pues en el caso de que vinieran enemigos a la ciudad había que temerlos más que a los de fuera... se les había prohibído que anduvieran por las calles desde la oración hasta el amanecer, so pena de cárcel": Parrilla Ortiz, La esclavitud, 146. 
Acevedo repeated the same alarmist proposals before the governor of the Andalusian coast, the Duke of Medina Sidonia, in 1617: "He has warned the city about the great inconveniences that have resulted or could result from having and allowing in it so many Moors and Turks, both captive and ransomed, who have come from outside to work and earn money."143 In 1646 the governor of Cádiz published a decree that gave six days' notice for "all Moors aged sixteen and older to leave the city, those who disobey being condemned to the galleys for life." The order does not appear to have been effective after the first attempt at compliance, because only a little later the town councillor Francisco Marrufo de Negrón claimed that "in this city there are many Moors, numbering more than 1,500, and many residents own them to hire them out by the day rather than use them themselves, while others buy them from slave-catchers to resell them." 144 In 1655 Count Molina placed the number of Muslims at three thousand, a figure he considered dangerous at a time when there was also a threat from the English. He suggested a maximum number of slaves per owner - some owners had eight or ten. ${ }^{145}$ But all these orders came up against the reality that Muslim slaves were essential for certain types of economic activities. One example was the exemption from the galleys for the bakers of El Puerto de Santa María, as we saw above. In 1669 Muslim slaves around the Bay of Cádiz were requisitioned from their owners for a year and employed in building the naval hospital. ${ }^{146}$ Early in the eighteenth century the Cádiz city council set its fear aside and asked the governor to stop sending Muslims away, because they played an important role in supporting many families:

Moors hand over their wages from day labor to their owners and thus are the sustenance of many widows and poor people who, because of their situation and age, could not maintain themselves decently in any other way. ${ }^{147}$

A similar situation obtained in Málaga, where residents also feared the growing number of Muslim slaves and freedmen in the city. Voices were raised in favor of expelling them, while others were vehemently opposed to a step that

\footnotetext{
143 Parrilla Ortiz, La esclavitud, 146-47.

144 Parrilla Ortiz, La esclavitud, 147.

145 Vincent, "Musulmanes y conversión," 79.

146 Domíguez Ortiz, "La esclavitud," 403.

147 "[L]os jornales que sacaban los moros los entregaban a sus dueños y así se sustentaban muchas viudas y personas pobres que, por su calidad y su ancianidad, no podían tener aplicación para mantenerse decentemente": Parrilla Ortiz, La esclavitud, 148.
} 
would harm their financial interests. In 1573 in Antequera and 1578 in Málaga, slaves were counted in preparation for expelling them to the interior. When another census was taken in Málaga in 1581 for the same purpose it provoked a report from the captain and town councillor Fortunio de Arteaga, who opposed the measure even while recognizing that Muslims caused problems and often escaped. ${ }^{148}$ We mentioned above that royal decrees in 1662 and 1667 ordered Muslim slaves sent to the galleys, noting especially "such a great number of slaves of this type, especially in the city of Málaga." ${ }^{149}$ When in 1670 the city's administrator of millones (a royal monopoly on goods) tried to apply the order by force, protests were so great that the queen decided to suspend it. Only two years later, however, in 1672 , there was a new condemnation of the large number of slaves and especially their bad conduct, so the Council of War authorized their total expulsion. The Council of Castile applied the measure only to Muslims. ${ }^{150}$

In Granada likewise, in about 1621 North African slaves were forbidden from living near the coast; they were ordered expelled from those areas to prevent them from escaping and collaborating with enemy corsairs. In 1627 the authorities were once again concerned about the large number of Muslims, who were accused of practicing polygamy and dissuading North Africans from converting to Christianity. The expulsion order was renewed in 1637 at a time when several slaves were executed for crimes committed by some of their number.

In 1657 the parish priest of San Matías complained that in "the so-called Moors' neighborhood" there were frequent disturbances, especially during weddings when "the cursed ceremonies of the Quran and dancing the zambra" took place. At around that time the Jesuits made greater efforts to convert Moriscos and other Muslims. ${ }^{151}$

In Madrid a considerable colony of free Muslims and slaves was forming, resulting in a prohibition in 1601:

No one in this city may own a slave who is not a baptized Christian, and those who are not [baptized] may not go out after dusk except with their owners or someone from the household with the owner's consent.

\footnotetext{
148 Vincent, "La esclavitud," 267; Bravo Caro, "Esclavos en Málaga."

149 Domínguez Ortiz, "La esclavitud," 401-02.

150 Domínguez Ortiz, La esclavitud, 36 -37.

151 Vincent, "Musulmanes y conversión," 76-77; Sánchez-Montes, La población, 129-33; Lera García, "Survie de l'Islam."
} 
It was claimed that the measure was needed in view of "the crimes that have been committed in this city," especially by Muslim slaves. The order continued,

And the Moorish or Turkish slaves (or from any other nation) who are not baptized within fifteen days after the publication [of this order] must leave the city on pain of losses to be applied by His Majesty's Chamber.

Just as in Cádiz, Málaga, and Granada, this severe measure was not carried out. There was a renewed request in 1619 to forbid the presence of slaves in Madrid:

[After it was decreed] that no one in this city could have Moorish slaves, and having waited for many days because those who most violated [the order] were great personages against whom we could not proceed, we stopped trying to proceed against the rest because laws must be equally applied and observed. Now we find greater inconveniences in disservice to our Lord God and with crimes that cause great scandal against the laws of nature. Therefore it seems proper to renew the proclamation and apply it to everyone, as is necessary.

The Moors were specifically accused of causing more violence in the streets:

There are many Moors in this city who serve some important people and others who dress like Christians so they cannot be recognized by night or by day. And recently some of them have been found at night bearing weapons and clubs and causing wounds, even to death, as happened to a poor man three days ago on the outskirts, [a crime] committed apparently by Moors. ${ }^{152}$

$15^{2}$ " $\left.\mathrm{N}\right]$ inguna persona tenga en esta Corte esclavo que no sea cristiano bautizado, y los que lo fueren no puedan andar en anocheciendo si no fuere con su amo o con persona de su casa con consentimiento de su amo ... y los esclavos moros o turcos o de otra qualesquiera nación que no sean bautiçados dentro de quince días después de la publicacion salgan de la Corte so pena de perdidos aplicados a la Cámara de S.M. ... [Que] no se pudiesse tener esclavos moros en esta Corte, y aviéndose guardado muchos días, considerando que los más que contravenían eran grandes contra quien no se podía proceder, se dexó de proceder contra los demás por la igualdad que an de tener las leyes y su observancia. Agora se an vuelto a hallar mayores inconvenientes en deservicio de Dios nuestro Sr. y grande escándalo que causan sus delitos contra las leyes de de la naturaleza. Y asi parece conveniente renovar el pregón y executarlo con la generalidad que es necesario. ...[E]n esta Corte ay muchos moros de que se sirven algunos grandes y otras personas los quales andan en ábito de cristianos de manera que de noche ni de dia pueden ser conocidos y estos días se han hallado algunos de noche con armas y porras y dado algunas heridas y 
Much the same was happening in Córdoba. In 1689 seven North Africans from the region of Oran, both slaves and freedmen, protested on behalf of all the city's Muslims against an order to expel them and confiscate their goods. They argued that they had lived there for a long time without causing any trouble, and eventually their petition was accepted. Some had converted, like Escaraman, who had been born in the province and whose father Guzmán and grandfather Velgas were Christians; but others, like Hamete and Mahamat, remained Muslim. ${ }^{153}$

In Murcia orders were also issued to expel or transfer Muslims. The city government of Cartagena decreed in February 1589, with the king's approval, that free Muslims who did not move inland within three days would be reduced to slavery - the men sent to the galleys and the women sold at public auction. The order must not have taken effect, because two years later in 1591 the royal magistrate commanded all Muslims, slave and free, to move outside the city limits within four days. The punishment was the same as before except that men would also receive two hundred lashes. In 1596 a new city decree ordered the expulsion of all Muslims who still lived there in spite of all the prior proclamations. A royal command this time, in 1615 , ordered the city's mayor to expel both free Muslims and slaves who were hired out, excepting only those who lived in their masters' homes; they had to move at least twenty leagues away from the coast. ${ }^{154}$ In Mula, about thirty kilometers south of Murcia, an altercation among Muslims in 1665 resulted in grave injuries to a woman named Busta. The aggressor was a freed slave, Hamete, and Muslims named Almanzor and Mazucan also took part. All of them lived in the same neighborhood and some were not baptized. ${ }^{155}$ In Loja, near Granada, free Muslims had become so numerous by 1626 that the procurador (town representative) Francisco Maldonado asked the Cortes to order them to leave. ${ }^{156}$

aun la muerte que sucedió en el campo tres días a un pobre hombre pareze cometida por moros": Domínguez Ortiz, "La esclavitud," 421.

153 Domínguez Ortiz and Vincent, Historia de los moriscos, 287-88.

154 Martínez Rizo, Fechas y fechos, 1:29, 56, 114, 199; 2:23. Aside from what all these orders and decrees tell us we know that there were many free Muslims from two examples. In 1735 the governors of Cartagena's charity hospital announced that they would not care for "sick slaves" unless it was proved that they were free (they must have meant cortados, those who were hired out); it seems that owners were refusing to pay for the cost of their care. In $175^{2}$ the same governing council settled with Amet, one of the hospital's slaves, on the price of obtaining his freedom.

155 Vincent, "Musulmanes y conversión,"79.

156 Vincent, "Musulmanes y conversión,"79. 
Little changed when the Bourbon dynasty ascended the throne in the early eighteenth century. The rigidly ideological state apparatus, under pressure from the Cortes, intervened once more to continue the status quo: an act of 1712 decreed that all free Muslims, including cortados, be expelled from Spanish territory. The justification was "the grave inconveniences that ensue in both political and spiritual matters," and "precautions [must be taken] to avoid having any more of them in my kingdoms." Out of an awareness of how deeply rooted the Muslims were, a period of time - though brief - was allowed them to travel to North Africa with their goods and their families. The measure did not include slaves, for whom it was decreed

that if they wish to be hired out no unfair contract be permitted, for I am informed that those are signed every day in this type of ransom, and to avoid any scandal or communication with these Moors who are hired out to work, and so that their number will not be too great.

For the freed Muslims, however, the order aroused more opposition than acquiescence. A group of former slaves in the shipyard at Cartagena declared that they would rather live in Spain than starve in Algiers. ${ }^{157}$ It was decided that the Muslims should be watched closely so that if their number rose again they could be expelled. ${ }^{158}$ We can see that fear of the enemy of the other faith was still intense in large swaths of Spanish society, and we wonder to what extent the War of Spanish Succession, which was still going on at the time, might have influenced the publication of this decree.

One anecdote that shows how flexible the frontier could be concerns a Moroccan named Guinaui Soliman (or Elguinaui Mauritano, or Elquina Ben Mauritano), about thirty-five years old, who left Salé for Lisbon in late 1704 or early 1705; he hoped to find his brother Muley Abderraman, "who had turned Christian" and lived in the Portuguese capital. On arrival, however, he learned that his brother had died. He obtained a passport signed by Catherine of Braganza, the former queen consort of Charles II of England and sister of Peter II of Portugal, since Peter was indisposed at the time. The document, dated 9 January 1705, ordered that he not be hindered in his journey on to Agadir or Algiers. 159

157 "[Q]ue en caso de que quieran cortarse no se permita en el ajuste ningún contrato injusto, como estoi informado se executan cada dia con este género de rescates, y que para evitar todo escándalo y comunicación de estos moros que cortaren y que no sea excesivo su número": Domínguez Ortiz, "La esclavitud," 422-23.

158 Domínguez Ortiz, "La esclavitud," 404-05, and Sociedad y Estado, 388. Anes, El Antiguo Régimen, 153 .

159 The original is in AHN, Estado, leg. 277. 
It is not clear why Guinaui decided to travel to Castile, concealing his Portuguese passport. He passed through Barcarrota, Salvatierra de los Barros, and Badajoz, from where he was sent to Madrid and imprisoned for fifteen days: he was taken for a spy because of his passport from an "enemy" nation (meaning both Portugal and England at the time). Guinaui claimed ignorance of that enemy status. This was the period of both the War of the Spanish Succession and the Moroccans' long siege of Ceuta.

It seems, nonetheless, that the Moroccan was treated with deference, since he was allowed a new passport from the Spanish monarch that ordered him not to be "offended or vexed." 160 He was taken under guard to Cartagena to take ship for Algiers; there he was judged "very suspect in all we have learned about him so far," but was allowed to depart for Oran with a passport dated 20 June. He arrived there two days later bearing a letter of recommendation from the chief magistrate of Cartagena, "dressed as a Christian and giving me to understand that he was related to the king of Meknes." In fact he seems actually to have been of Sultan Muley Ismail's family, as the authorities in Oran acknowledged: "He was a relative of the King of Meknes, as has been verified through the proof of two gentlemen of the Kingdom [of Morocco] who arrived today and kissed his head and his feet."

Once back on North African soil, Guinaui aroused much more suspicion than he had in the Peninsula. In view of his passport it was thought better not to "subject him to some pressure in order to discover the truth," but he was shut up in the fortress of San Andrés, "the strongest castle in this presidio." After a brief but intense interrogation (it had to be completed in an hour, since there was a ship about to sail for Algiers) he was revealed as an individual "of great variety and contradiction; in my opinion he is a very intelligent man who has explored Castile very thoroughly." The Portuguese passport was eventually discovered concealed in his turban - he claimed to have put it there only because it did not fit in his traveling wallet. He was also carrying three letters in Arabic from the Moroccan Kacem Ben Mansor of the Ould El Yub tribe, who was a slave in Cartagena. One of them, dated August 1702, begged for a ransom costing thirty reales, and he was supposed to convey all of them to the sultan of Meknes. ${ }^{161}$ Guinaui claimed to know neither the slave nor his master, even though if he did not reveal the master's name he was threatened with "suffering severe imprisonment and being punished as a spy and an enemy of the King's armies."

16o Passport dated 22 May 1705: AHN, Estado, leg. 277.

161 The record consists of five documents in Arabic including three letters from Kacem Ben Mansor: AHN, Estado, leg. 277. See Khalifa, "1705: Un notable marroquí." 
There were other contradictions as well: he claimed "to have spent a few days in prison as the king's slave, after which they released him," an episode that seems improbable. He also said he had arrived in Madrid from Ceuta, but under questioning could not describe the route from one to the other ("he does not know the ports"). The authorities in Oran concluded that he was "a rascal ... undoubtedly a spy, and very clever." He was forbidden the freedom of the presidio, ${ }^{162}$ but once he left it appears that the matter was closed. ${ }^{163}$

Clearly these reiterated expulsion orders were either not obeyed or obeyed only occasionally and in part; it was too difficult to follow them without damaging established interests. For instance, in 1708 the "Moors of peace" who had allied with the Spanish in Oran and Mazalquivir arrived in Málaga with the surviving troops after Algiers occupied both presidios. ${ }^{164}$ They do not appear to have been subject to Philip v's decree of 1712 to expel all Muslims, both slave and free, from his kingdoms. The same appears true of the slaves who worked in the shipyard at Cartagena, as we shall see below in section 4.5.

In fact the measure most commonly adopted was to deport Muslims to the center and north of the Peninsula. The monarchy sent many free and freed persons, converted or not, to Navarre, Palencia, Fuenterrabía, and La Coruña, and even to Naples, Milan, and Flanders. ${ }^{165}$ The chief reasons for ignoring the expulsion orders were the types of work performed by Muslims and the demographic problems of the seventeenth century. A good proportion of freedmen and cortados (those working to earn their liberty) decided to remain in Spain once they were free, whether or not they became Christian. They performed all kinds of hard labor that did not attract the rest of the population, because of its harshness and low pay and because such "slaves' work" was dishonorable. Among these were the professions of hauler, water carrier, stevedore, and unskilled laborer in hospitals and fortifications, though many other slaves

162 Carlos Carrafa, Admiral of Oran, to Michel-Jean Amelot, Marquis of Gournay, the French ambassador and close ally of Philip v, Oran, 23 June 1705; Carlos Carrafa to José Carrillo, Secretary of War, Oran, 23 June 1705; report on Guinaui's testimony in Juan Bautista Ballesteros, chief magistrate of Oran, 23 June 1705: A HN, Estado, leg. 277.

163 As we learn from the letter that José Carrillo sent to Marquis of Mejorada, secretary of the universal office, Madrid, 7 July 1705: AHN, Estado, leg. 277.

164 On 1o November 1716 Musa Bendar, "Sheikh of Ifre ... one of the places that was subject to our lord king" near Oran (conquered by the Algerians in 1708) gave a power of attorney in Málaga to Lesmes García Sagredo, secretary to the Admiral of the Granadan coast. It empowered García Sagredo to represent him and petition the king and the Council of State in his name: Archivo Histórico Provincial de Málaga, Protocolos, leg. 2365, scribe Francisco Caballero Corbalán, fol. 714.

165 Tarruell, Orán y don Carlos, 269-70. 
worked as domestic servants or engaged in petty commerce. And it was the authorities themselves, particularly in port cities, who objected most strongly to their expulsion. A severe labor shortage, especially in the seventeenth century, made it impossible to replace Muslim slave or free workers, at least in eastern and southern Spain. Resistance to their expulsion or deportation also came from many slave owners who depended wholly or in part on income from their slaves who were lent out to work. Everything indicates that the relative depopulation of coastal areas, and the resulting labor shortage, was countered at least somewhat by a continual flow of North Africans, especially Algerians and Moroccans, into Spain. Maghrebis abandoned their home region for several reasons: constant civil wars and struggles for power, tribute-seeking raids by armed bands from Algiers and Marrakesh/Meknes, and frequent plagues and famines. Further, Spain's occupation of Oran and other presidios divided the population of their hinterlands into allies and enemies of the Spaniards. All these factors made Algerians and Moroccans feel defenseless and encouraged them to emigrate. Not every resident felt the same kind of pressure, which bore particularly on certain clans, lineages, and family groups that found no alternative to their predicament.

Free and enslaved Muslims were not expelled from Spain, not even from southern cities, in spite of the many expulsion decrees issued between 1502 and 1712, but continued to be present throughout the Spanish domains. Two examples will illustrate this reality. In the sixteenth century a man named Ali was arrested by the bailiff in Valencia and sold into slavery. An Algerian corsair who had been attacking the coast, "he was a corsair who came off his ship to rob, and remained on land by chance." For a year he lived "always at liberty, until he was arrested," and was able to travel between Madrid and Valencia. ${ }^{166}$ Two centuries later, in 176o, twelve Algerian corsairs who were taking a captured ship to their home port were shipwrecked on the coast of Galicia. They pretended to be "Moors of peace" but were eventually unmasked and imprisoned in Pontevedra, presumably as slaves. Their "Moors-of-peace" stratagem shows that the condition of being both a Muslim and free was well known and accepted in Spain at the time. It also reveals that North Africans, at least those who went to sea, knew something about the workings of Spanish society. ${ }^{167}$

In light of all the above I prefer to speak of Spanish pragmatism - or convenience to be respected within certain limits - in dealing with free or enslaved Muslims in the royal dominions, in hopes of ensuring similar treatment for

166 Pomara Saverino, "Esclavos, identificación."

167 Barrio Gozalo, Esclavos cautivos, 137. 
Spaniards, both free and enslaved, in Muslim lands. Such pragmatism presupposes a level of tolerance that has traditionally not been admitted in the relations of the Catholic monarchy with Muslim rulers.

As an example, I present an issue that some historians have taken as proof that the Spanish monarchy had no wish to negotiate: the enslavement of Muslims traveling on board European ships when those vessels were intercepted at sea or detained in Spanish ports. ${ }^{168}$

There is no question that such enslavements were common. In 1727 two Maghrebis, probably Moroccans, were seized aboard an English ship captured by Catalan corsairs off Lloret. ${ }^{169}$ In 1733 three Moroccan merchants were bound from Gibraltar to Livorno in an English ship under Captain Joseph Robinson, carrying a thousand pesos, when they were captured by two Catalan corsair vessels and reduced to slavery. ${ }^{170}$

In many other cases, however, authorities in port cities were not hostile toward Muslim passengers who arrived on foreign vessels for whatever reason; ${ }^{171}$ they were either not disturbed or were allowed to disembark. In 1626 a boat arrived in Barcelona that "came from the region of Bougie with four Christian sailors and a pregnant Moorish woman."172 In 1629 six Turks, four men and two women, were aboard a French boat that stopped at Sant Feliu

168 Windler, "La diplomacia y el 'Otro'."

169 On 18 October 1727 a North African corsair vessel sent its launch into the bay of Lloret and captured two boats, one a fishing boat and one transporting wheat, though their crews jumped overboard and reached land. From the nearby town of Tossa four boats were armed and pursued the corsairs, "who were forced to flee leaving the two boats, recovering the main launch that they had placed in one of them - which they had not been able to do with two that they had placed in the other, because to save themselves in that launch they had jumped overboard, and despite all the fire aimed at them from the vessel with cannon and from the launch with rifles they caught them and had them in custody" ("los que se vieron precisados a huir, y dejar los dos laudes, recogiendo la lancha principal, que havian puesto en el uno, lo que no habiendo podido executar con dos que havian puesto en el otro, pues para salvarse ellos â la dha lancha se havian echado al mar, y que no obstante el gran fuego que les hizieron desde el navio con los cañones, y de la lancha con escopetas los havian cogido, y tenían en custodia"). Both the capturers and the captured were placed in quarantine: IM HB, FS, serie V, leg. 7, fols. 101-O2, 2 November 1727.

170 They were two Catalan vessels armed as corsairs, captained by Pablo Comas and Juan Caminada. Robinson's ship was coming from Brittany with sugar and other goods for Livorno, and stopped at Gibraltar to take on additional cargo; there three Moors came aboard. Though the ship was released the Moors were detained with their thousand pesos and other effects, and were placed in strict quarantine in the lazzaretto: IM HB, FS, serie v, leg. 8, fols. 127-30, 13 and 27 January 1733. Iм HB, FS, IV, 4, fols. 31-32, 26 January 1733.

171 Paradela Alonso, El otro laberinto; Pérès, L'Espagne vue par les voyageurs musulmans.

172 Імнв, RD, 135, fols. 130-33, 26 June 1626. 
de Guixols: "3956 lliures in Barcelona coin was commandeered in weights of eight, four, and two, plus the four Turkish men and two Turkish or Moorish women, clothing, merchandise, and other things." ${ }^{.13}$ A ship from Tunis under the French Captain Jean Banadich reached Barcelona in 1739 with more than twenty North Africans on board: "and he brings twenty-two or more Moors, and some of them appear very sick." The military governor (Capitán General) of Catalonia ordered the ship admitted into quarantine, contrary to the normal rules about vessels from North Africa. ${ }^{174}$

No harm seems to have come to the five Moors aboard a French ship that stopped in Alicante in June $1742,{ }^{175}$ nor to the nine who came to Barcelona from Mahón in 1753 in an English brigantine under Captain Raphael Tinther, though we know nothing more about what befell them. ${ }^{176}$ A Moroccan traveler named al-Zayyani, while sailing from Alexandria to Tetouan in 1758 , took a ship from Livorno that stopped at Mahón, which was in French hands at the time. The next stage of his journey brought him to Barcelona for seven days that seem to have passed without incident. ${ }^{177}$ Eleven Algerians aboard an English brigantine that put in at Cádiz in September 1785 met with no obstacles either. ${ }^{178}$ It was clearly not always the case that such passengers were forced to disembark, much less enslaved; they were almost always allowed to continue their voyage.

We need a detailed study of this question, including cases of Spaniards who while aboard English, French, or Dutch ships were seized by Muslim corsairs or authorities in North African ports where they docked. We already saw an example in Carlos Vidal from Valencia, who arrived in Algiers "in the security of an English ship" and in charge of its cargo but was put in chains by order of the Dey. ${ }^{179}$ Any study of how Spaniards dealt with Muslims captured in ships

173 Relacion en derecho.

174 IM HB, FS, VI, 8, fols. 19-25, 42-43; serie RA, 22 (1739), 163-64.

175 It was the Jesus, Maria y Santa Ana under Captain Joseph Lacruas, which had left Algiers on 9 June bound for France. It arrived in Alicante on the $15^{\text {th }}$ and continued its journey without incident, according to the Admiral of Valencia: Iмнв, Fs, Serie I, leg. 6, fol. 70; Marquis of La Mina to Barcelona's board of health, 22 June 1742.

${ }_{176}$ There were also two Greek passengers on board: I M HB, FS, I, 7, fol. 296, 28 September 1753.

177 Pérès, L'Espagne, 19-20.

178 The ship was the brigantine La Ana under Captain Thomas Phillips, which had come from Algiers and made a stop at Gibraltar. Though it carried raw cotton and a load of different fabrics it was piloted into the port, though with a strict quarantine and fumigation: Iм HB, FS, Serie I, leg. 16, fols. 46, Barón de Serrahí to JSA, 7 September 1785. According to Cádiz's board of health it docked on 14 September.

Vernet Ginés, El rescate, 42. 
of third countries must be extended to the corresponding ways in which Muslims treated Spaniards whom they encountered under the same conditions.

\subsection{More Merchants Than Expected}

At the outset of this section we should review the history of commerce with Muslims in the Peninsula from the eighth century to the Christian conquest of Granada in 1492. ${ }^{180}$ From that date onward the Mudejars (Muslims remaining in the Christian kingdoms) and the defeated Granadans (soon called Moriscos) enjoyed a degree of freedom, even in religion; we should therefore include them in this study of negotiations between Christians and Muslims. I will limit myself, however, to negotiations with Muslims of the Maghreb and the Ottoman Levant. I remind the reader here that in 1502 in Granada and Castile, in 1515-1516 in Navarre, and in $15^{2} 6$ in Aragon the Muslims were forced into baptism and became officially Christian; therefore after 1492 for a period of ten to thirty-five years (depending on the region) economic, social, and cultural dealings continued between the Christian majority and the Muslim minority. Commercial activity between the Spanish monarchy on the one hand, and the North African countries and Near East on the other, continued throughout the Early Modern age. That situation was possible in the sixteenth century thanks to the monarchy's North African policy, as we described in our Introduction. It took the form of established alliances, often involving vassalage, with different North African kingdoms. Commercial ties with Egypt and coastal Syria existed until the Ottomans conquered the Mamluk empire in 1516 but actually continued until 1528 , because until then the Ottomans still recognized the Catalan consulate in Alexandria. ${ }^{181}$

Commerce with the eastern Maghreb was possible thanks to many treaties signed with different local rulers: as we noted in the Introduction there were thirteen with the kings of Tunis, two with the king of Kairouan $\left(1549,155^{2}\right)$, and two with the sheikh of Djerba $(1520,1541)$. In the central Maghreb there were ten similar treaties with the rulers of Tlemcen. ${ }^{182}$ Trade was also possible with all the cities that Spain occupied, at least until they were retaken by North Africans or Ottomans: Algiers, Bougie, Tunis, Bône, Honaine, and others.

180 Miller, Guardians of Islam; Constable, Trade and Traders in Muslim Spain.

181 Departures of Catalan ships to Alexandria are registered at least until 1523: Martín Corrales, Comercio de Cataluña, 186-93, 6o2-o3. López de Meneses, "Un siglo de consulado."

182 Mariño, Tratados internacionales. 
For instance, the Capitulation signed by Charles v and King Muley Hasan of Tunis in 1535 stipulated that

the vassals and subjects of both parties may arrive, live, and negotiate on equal terms in the kingdoms, lands, and domains of both parties, freely, openly, and in entire good faith. ${ }^{183}$

And along the same lines, in negotiations between the Spanish and the sheikh of Djerba in 1541 the sheikh asked that his subjects have complete freedom to conduct business in Spain: "That [they] be able to deal in the lands of His Majesty just as his own vassals do."184

On the Moroccan coast the monarchy's policy was based not so much on treaties (though some were attempted) as on trying to maintain tactical alliances, not always successfully, against the common enemy, the Ottomans. There was trade between the plazas or fortified ports that Spain occupied intermittently and their respective hinterlands: Cazaza, Santa Cruz de Mar Pequeña, Larache, and the Portuguese ones that fell into the Spanish orbit when the two kingdoms were unified in the late sixteenth century. Then there were the more permanent presidios that Spain held throughout the Early Modern period: Oran, Mazalquivir, Melilla, El Peñón de Vélez de la Gomera, El Peñón de Alhucemas, and Ceuta. ${ }^{185}$ But it is also true that there were frequent armed clashes between the two sides.

There are many historical studies of Hispanic-North African commerce between the early sixteenth century and the second half of the eighteenth, that is, up to the time when the Spanish monarchy signed peace treaties with the rulers of North Africa and the Ottoman Empire. Some are general views that cover this entire period. ${ }^{186}$ Others are more focused on specific ports and coastal regions of Spain: Cádiz, El Puerto de Santa María and other ports on the Bay of Cádiz, ${ }^{187}$ Málaga and its coastal

183 "[Q]ue los vassallos y subjectos de una parte y de otra podrán venir, estar y negociar recíprocamente en los Reynos, tierras y señoríos de una parte y de otra, libre y francamente y todo con buena fee": Mariño, Tratados, $42-52$, quotation at 5 o.

184 Mariño, Tratados, 116-18, quotation at 117.

185 For full information on all the presidios conquered by Spain in the sixteenth century see Mariño, Tratados. For Oran in the seventeenth and eighteenth centuries see Fe Cantó, Orán (1732-1745); Alonso Acero, Orán-Mazalquivir, 1589-1639.

186 Martín Corrales, "Orán, entre fortaleza y mercado," "El comercio de España con los países musulmanes," "De cómo el comercio se impuso," and "Comercio en la frontera"; Bunes Ibarra, "Relaciones económicas."

187 Martín Corrales, "Le commerce de la bahie de Cadiz" and "El comercio de la bahía de Cádiz"; Margado García, "Las relaciones entre Cádiz y el Norte de África”; Rumeu de 
environs, ${ }^{188}$ Valencia, ${ }^{189}$ Majorca, ${ }^{190}$ Catalonia, ${ }^{191}$ Murcia, ${ }^{192}$ and the Canary Islands. ${ }^{193}$ There is research on trade between Spain and certain countries: Morocco (especially Tetouan and the coastal Rif), ${ }^{194}$ Algiers, Tunis, and the Ottoman Empire. ${ }^{195}$ We have monographic studies on specific goods such as cereals, which virtually monopolized shipments from North Africa; ${ }^{196}$ silver, especially in exports to the Muslim world; ${ }^{197}$ and wool, ${ }^{198}$ silk, ${ }^{199}$ and other products. ${ }^{200}$ There is information on people who took part in commerce - such as Jews acting as middlemen ${ }^{201}$ - and on clandestine trade and smuggling. ${ }^{202}$

Armas, Cádiz, metrópoli del comercio; Sancho de Sopranis, "Las relaciones mercantiles entre Cádiz y Marruecos" and "El comercio entre el Puerto de Santa María"; Anon., "Relaciones entre España y Marruecos," 132.

188 López de Coca Castañer, "Granada, el Maghreb," "Vélez de la Gomera," "Esclavos, alfaqueques," and "Relaciones mercantiles entre Granada y Berbería"; López Beltrán, "Fiscalidad regia" and "Notas sobre la expansión castellana"; Cabrillana Ciézar, "Notas sobre las relaciones de Málaga" and "Málaga y el comercio norteafricano”; Bejarano Robles, "Reanudación del comercio de Málaga con África."

189 Blanes Andrés, "El Mediterrani," "Mercaderes, productos," "Las embarcaciones, los mercaderes," and Valencia y el Magreb; Salvador, "El Reino de Valencia y el continente africano" and "Datos sobre el comercio con el Norte de África."

190 Seguí Beltrán, "El comercio del reino de Mallorca"; Juan Vidal, "El comercio del trigo" and "Le commerce du blé."

191 Martín Corrales, Comercio de Cataluña con el Mediterráneo musulmán and "El comerç de Catalunya amb el Nord d'Africa."

192 Montojo Montojo, "Las redes mercantiles" and "Relaciones y agentes comerciales."

193 Santana Pérez and Santana Pérez, La puerta afortunada; Lobo Cabrera, "Canarias y Berbería" and "Los vecinos de Las Palmas"; Rumeu de Armas, España en el África Atlántica; Ricard, "Recherches sur les relations" (two articles) and "Sur les relations des Canaries et de la Berbérie”; Alcalá Galiano, Santa Cruz de Mar Pequeña.

194 Martín Corrales, "Intercambios mercantiles hispano-marroquíes" and "El comercio español con Tetuán”; Lourido Díaz, "Los intercambios comerciales hispano-marroquíes.”

195 Martín Corrales, "Les relations commerciales entre Tunis et la Catalogne," "El comercio de España," "De cómo el comercio," and Comercio de Cataluña; Bunes Ibarra, "Relaciones económicas."

196 Lourido Díaz, "El comercio del trigo."

197 Martín Corrales, "La Saca de plata americana." A large proportion of the enormous amount of exported coin was shipped on behalf of third countries: Cherif, "Introduction de la piastre espagnole"; Rebuffat, "Les piastres."

198 Martínez Torres, "Plata y lana para el 'infiel."

199 Martín Corrales, "The Silk Trade," "El comercio de la seda," and "Exportación del vino catalán."

200 Martín Corrales, "Exportación del vino catalán”; Ricard, "L'Espagne et la fabrication des bonnets"; Koehler, "Ce que l'économie privée importait."

201 García-Arenal and Wiegers, A Man of Three Worlds; López Belinchón, "Aventureros, negociantes"; Martín Corrales, "Comercio en la frontera."

202 Gozalbes Cravioto, "Andalucía y el contrabando." 
Nonetheless, Muslim rulers almost always placed their commercial exchanges with Christian Europe in the hands of Christian negotiators, so that we have few references to Muslim tradesmen in European and Spanish ports.

We saw above how Maghrebi ambassadors and envoys who traveled to Spain in the first half of the sixteenth century were often granted safe-conducts by the monarch, the viceroy, or local authorities; these documents, which were also issued to North African merchants, guaranteed their safety and activities while on Spanish soil. This situation, of which there are many examples, obtained until Spain surrendered Tunis in 1574. A royal decree of 1493 ordered that any Maghrebis who came to Málaga to trade should receive a safe-conduct from the mayor or the royal magistrate, who would be responsible for protecting them during their business in the city:

Because some Moors and others who come to that city with merchandise, or to negotiate other things that they need, usually demand a safe-conduct for their arrival, stay, and return, we order you that the guarantees given to such persons and Moors should be given to both groups alike, in the usual form and as justice requires. ${ }^{203}$

We know that such safe-conducts were meant for Muslims from across the Strait of Gibraltar because we have a model letter attached to the royal decree that instructs the magistrate and the mayor:

We make it known to every captain of their Highnesses who goes by sea, and to any other persons who are subjects or residents, and to other non-subjects, that they should and are obliged to keep the peace with the kingdoms and possessions of the king and queen our sovereigns: that $[$ name $], \ldots \ldots \ldots$ a Moor from abroad, resident of $[$ city $], \ldots \ldots \ldots \ldots$ has asked us for a safe-conduct to go and travel abroad and do [business], ... ...... ... of which we have been fully informed and for which we give him our letter of guarantee. ${ }^{204}$

203 "Porque algunos moros e otras personas que vienen a la dibcha cibdad con mercadurías o a negociar otras cosas que les cumplen, acostumbran a demandar seguros para su venida, estada e tornada, nos vos mandamos que los seguros que se devieren dar a las tales personas a las tales personas e moros los dedes ambos a dos juntamente, en la forma que se acostumbran dar e de justicia se deva hazer": López de Coca Castañer, "Los genoveses en Málaga," 44.

204 "Hazemos saber a todos los capitanes de sus altezas que andan por la mar e a otras qualesquier personas que sean súbditos e naturales, e a los otros no súbditos, que deven e son obligados a guardar la paz con los reynos e señoríos del rey e de la reyna nuestros señores, 
One tradesman who obtained a safe-conduct in 1494 was Hamet "from Salé, a merchant, living in the province of Barbary," making it easier for him to conduct business:

Wishing to permit and favor the negotiation of merchandise, through which the public affairs of our kingdoms and our royal prerogatives receive great utility and increase: therefore, recognizing that you our devoted subject Hamet from Salé, merchant, living in the province of Barbary, wish and intend to deal, trade, and negotiate in mercantile fashion in and for our kingdoms and lands, and travel with your goods through their seas and ports, and send and receive your representatives and factors; said goods, in our kingdoms and territories in our name, may be dealt in, sold, bought, and carried from place to place. ${ }^{205}$

It is interesting to note that the letter prohibited trade in "forbidden goods" such as "silver in bulk," military equipment, arms, and artillery, and that if a safe-conduct were revoked its factors would be informed "aloud by a town crier in the usual places in the city of [Palma de] Mallorca or another nearer city or town in the land of Barbary."206

In October 1494 the king granted a safe-conduct to the Jew Salomon Milaquin for a journey to North Africa, "with two Moors in his company," so that they could load a ship with oil, raisins, and other products - as long as they were not forbidden ones. ${ }^{207}$

The Moor Brahin, an alfaqueque or ransoming agent from Fez, gained a safeconduct in 1498 to collect "a household of a certain widow" of Aragon, with children, family members, and their goods, and take them to his homeland:

que ... moro de allende, vezino de..., nos pidió seguro para yr e pasar allende a fazer... de lo qual ovimos plenaria información e le dimos nuestra carta de seguro": López de Coca Castañer, "Los genoveses," 44-45.

205 "Queriendo dar lugar e fauorecer la negociación de la mercaduría, para la qual cosa publica de nuestros reynos y los drechos reales nuestros reciben grande utilidat e augmento, por tanto, atendido que vos, deuoto nuestro, Hamet de Sale, mercader, habitante en la prouincia de la Barberia, desseays y havueys deliberado tractar, comarciar, comerciar e negociar mercantiuolament en e por nuestros reynos y tierras, y con vuestras mercadurías nauegar por las mares y puertos de aquellos, y embiar y tener vuestros procuradores y factores, que las dichas mercadurías, en los dichos nuestros reynos y señoríos en vuestro nombre, tracten, vendan y compren y lleuen de unos lugares a otros": Documentos, 4:479$80,531-32$.

206 Letter from Ferdinand the Catholic, Segovia, 6 July 1494, Documentos, 4:479-8o.

207 Letter from Ferdinand the Catholic, Segovia, 3 September 1494, Documentos, 4:532. 
We give permission and license to Brahin the Moor, a ransoming agent from the kingdom of Fez, who without incurring any punishment at all, at any time and place that he wishes and prefers, may bring out at one time, from any city, town, or village of our kingdom of Aragon that he wishes, a household of a certain widow with her sons, daughters, daughters-in-law, grandsons, and granddaughters whom he may choose, because they are the king's subjects; and that the said mother, sons, daughters, daughtersin-law, granddaughters, and grandsons who live in a house with a single patrimony or individual shares, with all they own of gold, silver, coins, jewels, clothing, adornments, bedding, horses, and other goods, that household of Moorish men and women may pass through any of our kingdoms and embark from any port or beach on any ship that they wish and are able to do, until he has transferred them and placed them across the sea in the land of the Moors. ${ }^{208}$

We have seen other instances in which North Africans in financial straits received help from the king to return to their homelands. In 1499, for instance, the monarch ordered the viceroy and the representative of Majorca to provide clothing and funds to visiting Moors so that they would depart contented. ${ }^{209}$

In around 1505 a man named Abrahen Zerchel, a "squire" to Ali Barrax who ruled Chaouen at the time, appeared in Málaga. Because he spoke Spanish fluently, he was probably a Nasrid exiled from Granada. After buying and selling goods he gave a power of attorney to a resident of Setenil, authorizing him to collect debts from former Christian captives. By 1508 he was in Granada and received a passport from the Count of Tendilla, valid for sixty days, with other letters of introduction to local authorities in eastern Andalusia meant to help him collect debts he was owed. He also formed relationships with local artisans. He was arrested and jailed in August 1508 in Málaga, probably because he

208 "[D]amos, licencia y libera facultad al Brahin, moro, alfaqueque del reyno de Fez, que, sin incorrer en pena alguna, cada y quando quel quisiere y bien visto le será, pueda sacar, por una vez tantum, de aquella ciudat, villa o lugar deste nuestro reyno Daragon que el quisiere, una casada de cierta viuda, con sus fijos, fijas, nueras, nietos y nietas quel escogerá, pues sean de realenco, y que las dichas madre, fijos, fijas, nueras, nietas, nietos viban en una casa con una fazienda, siquier bienes indivisos, con todo lo que tuvieran de oro, plata, moneda, joyas, vestidos, atabios, ropa, cabalgaduras e de otros bienes y pasar la dicha casa de moros y moras por qualesquier reynos nuestros, y embarcarlos en qualesquier puertos, playas e fustas que quisiere e podiere, fasta transferirlos y ponerlos allende el mar, en tierra de moros": letter from Ferdinand the Catholic, Zaragoza, 9 October 1498: Torre, Documentos, 6:146.

209 Ferdinand the Catholic, 5 August 1499, Documentos, 6:196-97. 
owed a debt to one of the town councillors: that official had given him a sum to rescue a Christian captive, but the man was still not free. ${ }^{210}$

We know of Muslim traders who were admitted to the port of Valencia: they were allowed to "deal, trade, and negotiate in mercantile fashion in and for our kingdoms and lands, and travel with [their] goods through their seas and ports," in the language of the document we saw above. ${ }^{211}$ In the late fifteenth and early sixteenth centuries several North African merchants arrived in Valencia aboard Venetian galleys. ${ }^{212}$ Though they were sometimes abused by local residents and authorities, the monarchy intervened on several occasions to put an end to such treatment. ${ }^{213}$

The Valencian merchant Juan Allepus requested a license from the city's bailiff in 1510 that would allow his slave Mahomet de Marbella to make a business trip in the company of a Muslim freedman. ${ }^{214}$ In 1512 a tradesman from Oran arrived in the port of Valencia as a slave in a caravel, and when he claimed to be a free man who had been unjustly enslaved an investigation was opened to determine the truth. ${ }^{215}$

We also, however, hear of the opposite cases in which North African traders were impeded or forbidden when they tried to stay on Spanish soil. By a decree of 1502, Muslim merchants detained at a distance of twenty leagues from the coast would "become slaves of the king, as is the current practice."216 We hope for studies in greater depth that will clarify the issue.

In the seventeenth century news about Muslim merchants in Spanish territory becomes less frequent, but there were cases in which they were allowed into a port without being detained, expelled, or enslaved. Between 1585 and 1602 two Muslim tradesmen were in Málaga together with the Jew Judas Malaqui, and one of them stayed in the city for at least four years while he conducted

\footnotetext{
210 López de Coca Castañer, "Esclavos, alfaqueques."

211 Guiral-Hadziiossif, Valence, 342-46.

212 We know of their presence because Muslim captives in the city approached them seeking help: Cortés Alonso, La esclavitud, 139.

213 In October 1491 the Spanish monarch ordered eighteen North Africans captured at sea to be freed, probably because they were subjects of a Maghrebi ally. In 1494 new orders prohibited capturing Moors in North Africa. In 1508 the bailiff of Valencia forbade any injury to the persons or goods of Moors who arrived on Venetian galleys, though they were not allowed to disembark: Cortés Alonso, La esclavitud, 359, 495, 503, 517-18.

214 Cortés Alonso, La esclavitud, 131.

215 His name was Yucef Abrauda and he had come from Oran with at guiatge or safe-conduct from Count Pedro Navarro that allowed him to proceed to Borja to ransom his wife and daughter: Cortés Alonso, La esclavitud, 121, 138.

216 Martínez Almira, "El intercambio de moros cortados," 241.
} 
Malaqui's business. ${ }^{217}$ Between 1611 and 1632 a group of twenty-seven individuals, almost all from Oran and some identified as merchants, were accused of "Mohammedanism" and pursued by the Inquisition in Murcia. ${ }^{218}$ The retinue of the Persian ambassador Denguis Beg, who spent 1611-1612 in Madrid, included Coja Regeb, considered an expert in commerce. A few years later, in 1620, two other Persian merchants were plying their trade in Madrid: "they brought no particular business from their king, but [only wished] to sell and employ their goods." They do not seem to have been hindered in their trade, but on 6 October they tried to kill an Armenian from Robert Sherley's delegation, one of the embassies that Shah Abbas sent to the Spanish court. The Council of State ordered the two Persians arrested, though it is not clear what their links to the Englishman might have been. ${ }^{219}$

North African corsairs sometimes sailed along the Spanish coasts and even landed to try to sell the spoils from their captures. In 1601 an Algerian frigate "of fifteen benches, flying a safe-conduct flag," approached Ibiza to sell a cargo of cowhides: "they wanted us to buy one thousand cowhides out of three thousand five hundred that they had taken from a French settee," and "to make the deal two Moors disembarked and because there was no money, [though they were] giving them at a low price, the purchase was not made."220 In 1643, in the course of negotiating the rescue of men captured off Andratx in the bay of Palma, three Algerian corsairs came ashore in Palma to buy fruit and supplies. ${ }^{221}$ Such incidents may have occurred fairly often and occasionally been successful.

There are fuller records for the eighteenth century. In 1763 Agi Gasep, a Moor from Tripoli, arrived in Barcelona in a packet-boat loaded with wheat, captained by a Minorcan (and under the English flag, since Minorca was an English possession at the time). Gasep presented a formal request to be led in by the pilot, sell the wheat, and use the profits to buy certain goods: "And having been allowed pilotage he has come to unload that wheat in this city, wishing to spend the profits on products and fruits of the land." He asked "permission to come on land and enter the city to carry on his business." The Captain General of Catalonia, the Marquis of La Mina, consulted the Board of Health because

217 Tarruell, "Circulations," 257.

218 Vincent, "Musulmans et conversions," and its Spanish version "Musulmanes y conversión" in El río morisco, 78 .

219 Gil Fernández, El imperio, 1:79 ff., 2:414-21; Alonso, "Embajadores de Persia"; Davies, Elizabethans Errant; Penrose, The Sherleian Odyssey; Ross, Sir Anthony Sherley.

220 Tarruell, "Circulations," 136.

221 Deyá Bauzá and Oliver i Moragues, "El Mediterráneo bipolar," 61. 
he wanted to know if there was "any example in this capital that would give him licence to be admitted as he asks, in view of his religion." The Board made no objection on grounds of health, since the ship had been piloted in, and declared itself not competent to rule on the issue of religion. There is no record of Gasep's having been denied. ${ }^{222}$

On 28 October 1775 Mula Osman, a Turk from Crete ("Candia"), arrived in Barcelona on the English brigantine Anglois under Captain Pierre Marqués as the supervisor of its cargo. Because the ship had stopped at Majorca it had the proper approvals from the authorities there. The island's Captain General had issued Mula Osman a passport that described him as "twenty-five years old, tall in stature, with black hair, a short beard, and black eyes”:

We grant a free and assured passport to Mula Osman, a Turk from Candia, who comes in charge of cargo in the brigantine from Mahón under Captain Pierre Marqués and will continue his journey to Barcelona. And we order all Ministers of War and of Justice who are under our jurisdiction as well as those who are not. We ask and request that they place no impediment to his voyage but rather give him [any] assistance and help he may need, as is proper in service to the king.

Osman, who enjoyed official protection from the French consul Bautista Albert, sold his goods in the city (dried beans and peas from Tunis, which he sold on the Catalan coast to a Greek, Nicolás Telemachi), and bought others. Since he was going on to Marseille he hoped for "payment for his foodstuffs after disembarking, to be converted into letters." 223

Also in 1775 a French ship under Captain Souffret arrived in Barcelona from Tripoli. Five Turks, including two "Moors," were on board and one of them, Sidy Amer from Crete, brought a load of barley. They were put in prison, causing the French consul in Barcelona to protest that the action would interfere with French commerce in the Levant. He did not obtain their freedom even though

222 Report by Agi Gasep, who arrived in the packet-boat of Captain Lorenzo Vendrell of Mahón: IM HB, FS, Serie I, vol. 11, fol. 212, 6 May 1763; Serie v, vol. 10, fols. 113-14, 5 May 1763. 223 "Concedimos libre y seguro Pasaporte, á Mula Osman turco de Candia, que viene de sobre cargo del Bergantin Mahones del Capitán Pierre Marqués, y Continua su viage, à Barcelona. Y ordenamos â todos Ministros de Guerra y Justicias sujetos â Nuestra Jurisdiccion, y â los que no lo son. Pedimos y encargamos no le pongan impedimento alguno en su viage antes bien le den asistencia y favor, que necessitare por convenir asi al Real Servicio"; "[L]e païement de ses denrées après le débarquement et le convertir en Lettres": Archives de la Chambre de Commerce de Marseille, Série K. 197. Letters from Aubert dated 3 November, 8 November, and 4 December 1775. 
he asked that they be transferred to a better prison and one of them, who was ill, be taken to a hospital; eventually a royal order placed them at liberty. The French consul asked for reparations:

An indemnity should be given to the passengers for the injury done to them and for what they have suffered during sixteen days of a most harsh and humiliating imprisonment. ${ }^{224}$

Amer and the captain canceled their mutual contract, signed in Tripoli the preceding 19 May, and separated

on condition, however, that Sidy Amer in payment for his expectations shall be reimbursed with fifty zequins [a gold coin] ... for the value of onequarter of a month's salary that he has sacrificed for them, even though according to his contract he could have demanded to be conveyed to Tripoli to complete his journey.

The Spanish government refused to pay any compensation, arguing that the French were engaged in illegal commerce. But the French kept up their petitions because their fortunes were tied to those of the Turks, as we see from Consul Aubert's correspondence:

He has earned several months' salary, for the money given as a mortgage to the Turks is for the gross amount, and its payment will suffice for all these purposes. ${ }^{225}$

Three more Turks and North Africans arrived in Barcelona in 1775 aboard a ship commanded by Captain Minuti, coming from North Africa with a cargo of barley. On this occasion, however, the ship with its crew, passengers, and grain was not allowed to dock but was sent on to Marseille. The French commercial

224 “Il devroit êttre alloüe aux Passagers, une indemnité pour l'injure, à eux faite, et pour ce qu'ils ont souffert, pendan seixe jours de la prison la plus dure et la plus humilliante": ACCM, Série K. Letters from Aubert dated 2 September, 30 September, and 7 October 1775 .

225 “[À] la conditión cependant que si Sidy Amer en païe de ses pretensions, celuy cy será rembourse de cinquante zequins Zermabout pour la valeur d'un quart de mois de salaire qu'il à sacrifié en leur faveur, quoique par son contrat el êut pût exiger d'aller finir son voiage à Tripòli"; "il a plusieurs mois de salaires gagnés; que l'argent donnè aux Turcs en Hipothéque est en argent Prix à la grosse, et qui actuellement le chargement se suffira à tous ces objets." Three letters from Aubert in previous note: ACCM, Série K, 197. 
attaché in Madrid acknowledged that it was blocked for purely sanitary reasons, since in general there was no opposition to receiving Muslim passengers on French ships: "It appears that Spain does not mean to dispute to the French flag the right to carry Turks or Moors as passengers on board."226

In short, in the sixteenth through the eighteenth centuries it was not unusual for Muslim merchants to be admitted to Spanish ports. It is clear that the conduct of Spanish authorities toward them was not always guided by an extreme intolerance based on a spirit of crusade. The instances we have described, to which others will surely be added after more research, suggest that economic and political considerations were operating as well.

\subsection{Muslims of Christ}

Conversion, to a Muslim, meant replacing one symbolic space - his or her own, with all its obligations - with another no less demanding Christian one. Not only belief and worship were involved, but also customs, practices, and the responsibilities of kinship. It is very difficult to study conversions of Muslims on Spanish soil in the Early Modern age because documentary evidence is widely dispersed. Everything suggests, however, that conversions were far more numerous and continuous than has been estimated before now. ${ }^{227}$ They certainly did not exceed the more than three hundred thousand Christian renegades thought to have embraced Islam, but they were important from a qualitative point of view: many members of ruling families, leaders of rebel tribes, and important personages from North Africa converted, especially in the sixteenth century. The phenomenon had quantitative weight also, however.

Up to now the best-known figures have been the exiled members of Maghrebi royal houses who came to Spain in search of support in regaining their thrones or consolidating their power: Wattasids, Saadids, Zayyanids, and Hafsids. Some of those expatriates decided to accept Christianity once they had exhausted all possibilities, however remote, of returning to power in their countries of origin: that was the case for dozens of members of royal families and probably as many more of their partisans, servants, and others in their trains. This array of conversions resonated greatly at the time, because these notable persons

226 "[I]l paroit que l'Espagne ne prétend point disputer au Pavillon François le droit d'avoir des turcs ou des Maures, Passagers à son Bord": Letter from Aubert, 8 November 1775: ACCM, Série K, 197.

227 An overview in Vincent, "Musulmans et conversions" and its Spanish version in El río morisco, $75^{-88}$. 
had preferred the Cross to the Crescent. We discussed many of these cases in Chapter 3. We will only stress here that aside from members of those dynasties themselves there were companions, followers, and domestic servants who converted as well, and also impostors - showing that conversion was more widespread than has been thought. There were also conversions among members of embassies from the Kings of Kuku and the Shah of Persia. ${ }^{228}$

Aside from this select group of members of dethroned ruling families or diplomatic delegations, there were thousands of Muslims who converted either voluntarily or under pressure. Both modalities overlapped throughout the period that concerns us.

Pressure was exerted on Muslim slaves, and also on freedmen, to convert to Christianity, and the Jesuits made a special effort from 1669 to $1683 .{ }^{229}$ Conversions were limited, however, for a variety of reasons. First, so as not to provoke similar pressures on Christian captives in cities in the Maghreb; second, the need for rowers in the galleys in the sixteenth and seventeenth centuries; and third, a similar demand for slave labor on public works (in shipyards, mines, fortifications, ports, roads, and other projects).

Most private slave owners, in the countryside or in cities, were not very interested in having their slaves convert because they feared losing many valuable kinds of labor that Old Christians were disinclined to perform. Nor did they want to lose their investment: conversion did not inevitably bring manumission, but there was greater pressure to manumit after a slave had been baptized. We have seen that the number of Muslim slaves in Spain in the Early Modern period has been estimated at three to four hundred thousand. How many of them became Christian? How many came to Spain intending to convert, or did so to ensure that they could remain? While perusal of the large bibliography on the topic suggest that there were thousands of conversions, scholars present their data in so many different forms that it is hard to reach consistent conclusions. ${ }^{230}$

228 Perpiñán Silla, "Dos visiones de la diplomacia hispano-persa"; Alonso Acero, "Being so Thoroughly Spanish, the Persian"; García Hernán, "Persian Knights in Spain" and "The Persian Gentleman at the Spanish Court"; Gil Fernández, El imperio luso-español; Cutillas Ferrer, "Las Relaciones de Juan de Persia”; Juan de Persia, Relación; Le Strange, Don Juan of Persia.

229 The Jesuits had many missions to convert Muslims in the Peninsula: Tirso González de Santalla and Juan Gabriel Guillén in Andalusia (1669, 1670, 1671, 1672, 1676), Francisco Poch in Barcelona (1676, 1679, 168o, 1682, 1683), and Antonio Moreno in Cartagena (1679): Vincent, "Musulmanes y conversión," 83-85, and "Les Jésuites et l'Islam Méditerranéen."

230 Many authors do not count the number of baptized slaves, and not all who do so differentiate between Muslims and blacks from sub-Saharan Africa. 
The best way to approach the question is to consider the Spanish and Portuguese fortified ports in North Africa, where there were thousands of slaves captured in open warfare or in mounted raids and expeditions. Many others, however, came to those ports voluntarily to choose slavery rather than lose their lives. It is hard to establish how many were baptized and how many not.

The years 1521 to 1524 were disastrous for the Moroccan regions of Chaouia and Doukkala: a famine caused by poor harvests was worsened by an epidemic of plague. Diego de Torres relates that many Moroccans were forced into the Portuguese plazas of Azzemour and Safi, seeking to sell their children and relatives to ensure that they would stay alive, even if enslaved. Other Muslims captured their coreligionists and sold them to the Europeans:

At the beginning of the year one thousand five hundred twenty-one such a great plague and famine came to all those lands that they would steal each other and sell each other to the Christians of those fortified places and so cheaply that a Moorish man or woman might be sold for a basket of figs or raisins, such was the hunger and want, except for the want of men. Many thousands of people died.

Torres added, "Today there are many slaves in Spain who were had at that time for such a price."231 Another chronicler of the time reported that more than sixty thousand people were taken to the Peninsula, especially to Portugal. ${ }^{232}$ Many sought to save themselves in the Iberian Peninsula at the expense of their freedom: hundreds of those slaves arrived in the Bay of Cádiz, and we can assume that many of them converted. ${ }^{233}$

In Oran between 1563 and 1599 at least 3,300 slaves were baptized (there is a gap in the records between 1581 and 1588). Most of them had been caught in raids conducted by members of the presidio's garrison, but they also included many black Africans. Most who converted did so under coercion, though a

231 "Al principio del año de mil y quinientos y veinte y uno, sobrevino gran peste y hambre en todas aquellas tierras, que se hurtaban los unos a los otros y se vendían a los Cristianos de aquellas fuerças y tan baratos, que acontecía dar un Moro o Mora por una sera de higos o pasas, tal era el ambre y la carestía si no era de ombres. Murieron muchos millares de gente. ... Oi dia ai muchos esclavos en España avidos en aquella temporada a este precio": Torres, Relación, 100-01.

232 The chronicle by B. Rodrigues states that in Azemmour a thousand slaves were being sold every day, and that about one hundred fifty ships filled with slaves left that port. In Safi it was much the same: Rosenberger and Triki, "Famines et épidemies au Maroc," esp. 129. See also Bouchareb, Os Pseudo-moriscos de Portugal.

233 For the period 1521-22 see Rumeu de Armas, Cádiz, metrópoli del comercio, 20. 
number of voluntary conversions seemed to stem from the desire to obtain a passport for travel to Spain. ${ }^{234}$ Baptisms continued into the seventeenth and eighteenth centuries. ${ }^{235}$ Famine in the Oran region brought 862 additional slaves into the town between November $175^{\circ}$ and March 1751, of whom 184 were baptized. 236

The largest number of North Africans - in fact, almost all the slaves captured when towns on the North African coast were conquered - entered Spain's closest ports, especially Cádiz, Málaga, and Cartagena, and the long seacoast between the latter two cities. In Cádiz, as we noted above, hundreds of Moroccans arrived either as slaves or in flight from the famine of the first half of the sixteenth century, and many of them probably converted. In the following century the number of slaves and the number of conversions both rose. ${ }^{237}$ Two detailed studies have sought to determine how many slaves were baptized. (See Table 2.) Of a total of 11,45 o between 1600 and 1749 there were at least 1,891 Muslims (Turks and North Africans). Another count made in the city gives us a total of 2,035 slaves baptized between 1700 and 1799 , with only 154 identified as Turks and Moors. ${ }^{238}$ If we combine the two sources and eliminate duplications we find at least 1,930 baptized Muslims, of whom 860 are called "Moors," 696 "Turks," and 364 "Berbers" (we subsume the Moors and Berbers under "North Africans").

We can see how many Muslims were baptized, but we do not know - and it is very difficult to determine - what percentage of all the Muslim slaves underwent conversion. Just as in the case of Oran, we have little information on how many turned Christian voluntarily; only rarely is it recorded that that was the case. Still, there is no doubt that many North Africans and even Turks arrived in Spain intending to become Christians. The few indications we have are not lacking in interest. In 1630 Guillermo, of North African origin, was baptized at his mother's request. Three baptized Turkish women, María Ángeles (1710), Ana María (1740), and Teresa Fisart, left sums to religious institutions in their wills. The Turk Andrés José in 1723 expressed a wish to be buried in the cathedral wearing the habit of Saint Francis. ${ }^{239}$

\footnotetext{
234 Bravo Caro, "El bautismo de esclavos."

235 For the seventeenth century see Vincent, "Musulmanes y conversión," 83.

236 Fe Cantó, "La grande famine de 1750."

237 In La Mamora(Mehdiya), which the Spanish seized in 1614, Jesuits, Capuchins, Dominicans, and Augustinians tried to outdo one another in converting the captured Moroccans, who would be sent immediately to Cádiz: Vincent, "Musulmanes y conversión," 82.

238 Morgado García, Una metrópoli, 130, 134, 146, 150; Parrilla Ortiz, La esclavitud, 96-97.

239 For Guillermo see Morgado García, Una metrópoli, 265; for the other cases see Parrilla Ortiz, La esclavitud, ${ }^{134-35}$.
} 
TABLE 2 Muslim slaves baptized in Cádiz, 16oo-1799

\begin{tabular}{lllll}
\hline & Total slaves & North Africans & Turks & $\begin{array}{l}\text { Total } \\
\text { Muslims }\end{array}$ \\
\hline $1600-1619$ & 714 & 136 & - & 136 \\
$1620-1639$ & 1,491 & 127 & - & 127 \\
$1640-1659$ & 949 & 206 & 1 & 207 \\
$1660-1679$ & 2,949 & 637 & 39 & 676 \\
$1680-1699$ & 3,718 & 90 & 540 & 630 \\
$1700-1799$ & 2,035 & 38 & 116 & 154 \\
& 11,836 & 1,234 & 696 & 1,930 \\
\hline
\end{tabular}

SOURCES: MORGADO GARCÍA, UNA METRÓPOLI ESCLAVISTA, 130, 134, 147; PARRILLA ORTIZ, LA ESCLAVITUD EN CÁDIZ, 96-98

Conversion efforts by the Jesuits from 1671 to 1681 in towns around the Bay of Cádiz resulted in baptisms as well. ${ }^{240}$ Many in the audience spoke Arabic. There was great resistance to attending the sermons because slaves did not want to lose their day's wages; the preachers proposed attracting them by paying an equivalent amount. ${ }^{241}$ It seems that in no other European city, not even in Rome, were there more baptisms than in Cádiz.

Málaga must have produced a large number of converts as well, and a few cases are recorded from the last third of the sixteenth century. ${ }^{242}$ Of the 575 slaves counted there in 1581 we know that at least 428 were Muslims, of whom 135 converted: they appear as 117 North African Christians, four black North African Christians, four Moorish Christians, one Christian "of the Moorish caste," two Christian Arabs, five Christians, and two children of Old Christians. ${ }^{243}$ There were baptisms in Málaga in the seventeenth and eighteenth centuries

240 A Jesuit mission to Andalusia in 1671 spent four weeks trying to convert Turks, North Africans, and descendants of Moriscos in Cádiz, El Puerto de Santa María, Jerez de la Frontera, and Sanlúcar de Barrameda. In 1681 they organized mass baptisms in Cádiz and Jerez: Vincent, "Musulmanes y conversión," 83-85.

241 Nine Muslims were baptized in Jerez in 1671: Domínguez Ortiz, "La esclavitud," 395; Vincent, "Musulmanes y conversión," 84.

242 Ali Belhagi in 1510, as well as five men and two women from Tunis: González Arévalo, $L a$ esclavitud en Málaga, 194-95.

243 Also fifty-four Moriscos: Vincent, "La esclavitud en Málaga," and its Spanish version in Minorías y marginados, 239-70. 
as well: the 1661 census registers 227 slaves of whom some were converts. ${ }^{244}$ By 1753 only forty-six slaves remained in Málaga, largely North Africans, of whom a few were baptized. ${ }^{245}$ We do not know how many arrived intending to become Christians or how many made the decision after they came to the city as slaves.

It is clear, however, that a good many converts arrived in Málaga of their own volition. A married couple who had entered El Peñón de la Gomera in 1565 asked for baptism and were sent to Málaga; they became the property of a resident woman who claimed them as her servants, so they might have been Moriscos who had returned to the Peninsula. One Almanzor had served in Melilla since 1583 in return for a daily wage and a little wheat and barley; he moved to Málaga with his family and converted, taking the name Luis Manrique. His son, known as Don Felipe de África, hoped to be a soldier in Navarre, Perpignan, or Fuenterrabía, but the king had him choose between Pamplona and Milan. Aduc Hamama, of a family of "Moors of peace," took temporary refuge in Melilla because of his compromised position, but after the danger passed he refused to leave the presidio and asked for baptism; he was sent to Málaga where, after converting, he took the name Francisco Pacheco. We know that he moved to Madrid in late 1586 and the next year was sent to Naples, where he served the viceroy as a soldier at least until $1603 .{ }^{246}$

Cristóbal, a native of the region around El Peñón de Vélez de la Gomera, was captured by the Spanish and sent to Málaga. In about 1589 he managed to escape to his native land, but once there

on considering the Christian religion and the Mohammedan sect, realizing its error, he returned of his own free will to Oran meaning to be instructed and receive the water of holy baptism ... [after some time] he took ship and came to Málaga where he was baptized a Christian, wishing to live and die as such through the grace of the Holy Spirit. ${ }^{247}$

244 Bravo Caro, "Esclavos al servicio." The Jesuits preached to Muslims in the open-air theater in 1669: Vincent, "Musulmanes y conversión," 84.

245 Several baptisms were recorded between 1750 and 1753 . Before the latter year there were María de los Dolores Rosa, her North African husband Cristóbal Andrés, and their children, four-year-old José and six-year-old María de la Encarnación. Teresa, also a North African, received baptism, as did Juan José Phelipe from Tetouan in 1750. Others were Juan Rodríguez and Francisca María Joachina in $175^{1}$ and María de la Paz "of the Moorish nation" in 1753: Bravo Caro, "Los esclavos de Málaga," 95-96. 104.

246 In 16o7 a María Jesús de África, resident in Milan, appears in the documentary record; she might have been the widow of Felipe de África. For Almanzor, Felipe de África, and Aduc Hamama see Tarruell, Orán y don Carlos, 268-71.

247 "[C]onsiderando la religión cristiana y la secta mahomética, cayendo en el error della, se bolvió de su boluntad a Orán con intençión de ser instruido y pedir el agua del santo 
In Cartagena, a city strongly oriented toward North Africa, there were conversions among Muslim slaves in general ${ }^{248}$ and galley rowers in particular. ${ }^{249} \mathrm{We}$ know of only a handful of cases but there must have been many more, because most of the slaves baptized in Oran in 1750-1751 were sent to Cartagena. ${ }^{250}$ In nearby Murcia conversions were frequent. In the first half of the seventeenth century the Jesuits there tried to convert Muslim slaves and published a "Method to be Followed in the Conversion of Moorish Slaves to our Holy Faith, with some Techniques for Attaining that End" (Método que se debe guardar en la conversión de los moros Esclavos a nuestra Santa Fe con algunas industrias para lograr este fruto). While they must have met with some success, a few converts returned to Islam: between 1611 and 1632 fifty-eight persons (of whom twentyseven had come from Oran) were pursued by the local Inquisition tribunal, meaning (with few exceptions) that they had once been baptized. Later on, in 169o, a survey identified forty-four Muslims (twenty-three slaves and twentyone freedmen), who probably included several baptized Christians. ${ }^{251}$

Of the cities in the interior we know most about Madrid and Granada, in both of which conversion might be forced or voluntary. Many Muslims came to Madrid from Africa in the very years of the expulsion of the Moriscos: large groups in 1609 and 1610 , resulting in one hundred fifty and sixty conversions respectively. In later years the number of baptisms seems to have declined in spite of the Jesuits' efforts. In 1669 no more than forty people ever attended one of their sermons, even though they preached in capacious spaces, and Muslims viewed them with suspicion. They performed ten baptisms in $1670^{252}$ and only 184 (of North Africans and Turks) between 1650 and $1700^{253}$

baptismo. ... [tras un periodo de tiempo] se embarcó y bino a la dicha Malaga, donde fue baptizado christiano y que como tal quiere vivir y morir mediante la graçia del spiritu sancto": Tarruell, "Circulations," 220.

248 A woman named Aysa had five children baptized between 1681 and 1692. Three children of Fatima, a North African slave, were baptized in 1692, 1694, and 1695: Sánchez Torres, "La esclavitud en la Cartagena."

249 In 1679 the Jesuits sent a mission to Cartagena that spent nine days attempting to convert Muslims, with three of those days devoted to galley slaves: Vincent, "Musulmanes y conversión," 83.

250 The greater part of the 488 slaves sent to the Peninsula: Fe Cantó, "La grande famine."

251 The author of the Método que se debe guardar en la conversión was Juan de Almarza. Of the forty-four Muslims listed in 169 o thirty-four were natives of North Africa and eight had been born in Murcia: Vincent, "Musulmanes y conversión," 78-79, 83-85.

252 On that occasion they organized a procession from the Jesuit house to the Imperial College in which several grandees of Spain, who were acting as godfathers, took part. In the same year, in a perhaps related incident, a Tunisian convert addressed his former coreligionists in Arabic. During such ceremonies the populace, including the nobility, would press around so closely that the new converts could scarcely move: Vincent, "Musulmanes y conversión," 78, 83-85.

253 Larquié, "Les esclaves," 6o. 
For Granada information for the sixteenth century is scarce ${ }^{254}$ in comparison to what we know of the seventeenth. In the 1600 at least 640 acts involving Muslims are noted in parish records. Of these 256 were baptisms, usually of the children of North Africans, 125 were burials, and 177 individuals are named in marriage records. We cannot simply add up these figures, since a single person might have participated in two or even three of the ceremonies. ${ }^{255} \mathrm{~A}$ few anecdotes suggests that baptisms were an important factor. ${ }^{256}$ In 1607 a group of North Africans arrived in Almuñécar, and forty of them (plus an unknown number of their wives and children) were baptized a few months later by the archbishop of Granada:

On 19 March of this year many Moorish men and women came to the city of Granada from Barbary with their children, having disembarked in the city of Almuñécar, coming to turn Christian and by order of His Majesty, who commanded that they be welcomed in the city of Granada and live in it. They received the faith, and to accomplish it the most illustrious Señor Don Pedro de Castro y Quiñones, Archbishop of Granada, gave them the water of holy baptism in the collegiate church of the Sacromonte with much solemnity and rejoicing. The number of the converted was more than forty, with their wives and children; the archbishop, as a pious prince, ordered them all to wear Spanish clothes, and even gave cloaks to the women, and likewise other charitable citizens gave them bedding and other items. And as for those who were married in the sect of Mohammed, they married them anew as is required by our Holy Mother Catholic Roman Church. ${ }^{257}$

254 Very few cases are cited in Martín Casares, La esclavitud, 426-28.

255 Sánchez-Montes González, La población granadina, 129, 209-13.

256 María, a North African slave, was accused of Islamic practices by the Inquisition in 1619: Martín Casares, La esclavitud, 427-28. A Muslim who had been baptized in the Alhambra in June $165^{2}$ was murdered six months later by his former coreligionists: Vincent, "Musulmanes y conversión," 78-80.

257 "En diez y nuebe días del mes de marzo deste año vineron a la ciudad de Granada muchos moros y moras de Berberia con sus criaturas, los quales desembarcaron en la ciudad de Almuñecar, viniendo a volverse cristianos y por mandado de su magestad, que mandó que se les diese coximiento en la ciudad de Granada y que abitasen en ella; recibieron la fee y para su cumplimiento el ilustrísimo señor don Pedro de Castro y Quiñones, arzobispo de Granada, les dio el agua del santo bautismo en la iglesia colegial del santo Monte ilipulitano, con mucha solemnidad y fiesta. Fue el numero de los combertidos mas de quarenta con mujeres y niños, a todos los quales el señor arçobispo como tan piadoso príncipe, los mandó vestir a la española, dándole hasta mantos a las mugeres y ansi mesmo otras personas particulares y caritativas les dieron cobertores y otras cosas y a lo que eran casados en su secta Mahoma los desposaron de nuevo como lo mandó la santa madre iglesia católica romana": Henríquez de Jorquera, Anales de Granada 2:533. Cited also in Vincent, "Les Jésuities et l'Islam." 
Once again for the following century we have few data about converts. Between 1727 and 1730 we can identify a coherent Muslim or crypto-Muslim community of 226 members from about fifty families, but they were essentially of Morisco origin. Though they were well integrated into the population the Inquisition of Granada condemned them for "Mohammedanism."258

In Barcelona the Jesuits also had conversion campaigns throughout the seventeenth century, directed chiefly at galley slaves: these were carried out in 1676, 1679, 1680, 1682, and 1683. Four Turks and three North Africans were baptized in the cathedral in July 1680.259 We know little about the eighteenth century, but one Mustafa Azen was baptized in $1723 .{ }^{260}$

We have information on many other towns and regions: in Andalusia Seville, ${ }^{261}$ Córdoba, ${ }^{262}$ Jaén, ${ }^{263}$ Huelva, Palos, and Moguer; ${ }^{264}$ in Extremadura

258 Vincent, "Musulmanes y conversión," 77.

259 The Jesuit leader there, Francisco Poch, preached 104 sermons between February and May 168o. In one session, in which in a dramatic gesture he held up a dead man's skull, he persuaded five galley slaves to convert. He organized processions in which galley slaves and musicians from the galleys took part, singing litanies and carrying torches, while volleys of cannon were fired from the ships: Vincent, "Musulmanes y conversión," 8o-86, and "Les Jésuites et l'Islam."

260 See the Relación verdadera of 1723. In 1762 a North African who had been captured off Barcelona and was serving out his quarantine in the lazzaretto expressed a desire to convert, and a priest who served there, Pasqual Massach, reported the presence of a "Moor who wishes to turn Christian": Ім нв, Fons de Sanitat, Serie I, vol. 11, fol. 97, 19 June 1762.

261 In 1672 the Jesuits managed to convert forty-four people there who were baptized in the cathedral: Vázquez Ruiz, "Una aproximación," 22o, and "Ad conversionem"; Domínguez Ortiz, "La esclavitud," 395. In 1679 they took over the Lonja in Seville as a space for proselytizing Muslims: Vincent, "Musulmanes y conversión," 84.

262 In 1593 a Moor was baptized: "he was first very well instructed, and he received holy baptism with great joy." In 1597 the baptized were Diego, Juan, and Diego, "Moors from Oran sent by the Count of Alcaudete." María, also from Oran, received baptism in 1598: Aranda Doncel, "La esclavitud en Córdoba," 154, 165. For Lucena see Aranda Doncel, "La esclavitud en Lucena."

263 Of 285 slaves sold in Jaén all were baptized except an eight-year-old North African boy named Embarca. About fifty of them were probably Muslims: Aranda Doncel, "Los esclavos en Jaén," 236-39. In 1677 it was Juan Francisco, "a boy of about four years, an infidel Moor by nation, son of an enslaved infidel Moorish woman." In 1685 Fatima was given the name María de Santa Rosa on baptism: "a five-year-old girl of the nation of Barbary, who said that her father was called Hamete and her mother Maimona." The source states explicitly that her mother consented to the ceremony: López Molina, Una década, 124-26.

264 In 1562 a North African was captured in the area of Tinto-Odiel; he alleged having arrived voluntarily by ship in order to become a Christian. He was eventually baptized in Moguer. In the same town in 1695 Catalina de Mesa, "of the Turkish nation," was manumitted without payment because she was going to marry a free man: "of her own will she was baptized and turned to Christianity and joined our holy Catholic faith": Izquierdo Labrado, $L a$ esclavitud, 1:290, 2:92. 
Badajoz, ${ }^{265}$ Llerena, ${ }^{266}$ Fregenal de la Sierra, and Montijo. ${ }^{267}$ We have further information on baptisms in Valladolid, ${ }^{268}$ Navarre, ${ }^{269}$ the Canary Islands, ${ }^{270}$ Majorca, ${ }^{271}$ and a few other scattered places. ${ }^{272}$

265 Baptisms in Badajoz included those of "Jerónimo and Hernando, Turkish slaves," in January 1552; Bartolomé, son of a Morisca named María, on 21 August 1573; María, daughter of Isabel, a Morisca, on 19 September 1574; Francisca Juana, daughter of Moorish slaves, on 20 September 1581; María, "a Moorish woman, newly converted to our holy Catholic faith," in 1587; in the same year Catalina, daughter of María, a "dark" Moorish slave woman. Three-year-old Antonio and six-year-old María, enslaved "Moors by nation," were baptized on 25 March 16o5; Mariana, "of the Barbary nation," on 15 March 1614; María de Gracia, an "adult Arab slave," in March 1666; Francisca, daughter of enslaved Moors, on 20 September 1681; María de la Cruz, "of the Turkish nation," on 3 May 1698: Cortés Cortés, La esclavitud, 51-52, 101-02, and "Aproximación a la esclavitud."

266 Two Turks from Timisoara were baptized in 1696, taking the names Juan Miguel and María de la Granada: Periáñez Gómez, Negros, mulatos, 85 .

267 In Montijo the convert was Juan, "who was a Moor by birth and turned to our holy Catholic faith of his own will" on 25 May 1638. In Fregenal de la Sierra the local priest, Alonso Calvo Romero, owned five slaves; one of them was Juan de la Cruz, "an African whom they brought from Oran at my expense and is baptized" in 1649: Cortés Cortés, $L a$ esclavitud, 51-52, 101-02.

268 The baptized included María de la Concepción from Tunis, the Turks Francisco de Rojas and Casarrami, and Pedro Moreno from Bougie: Fernández Martín, Comediantes, esclavos, $145^{-49}$.

269 Juan Bautista de Cardona was captured at the battle of Lepanto and kept in slavery until 1595, when he was freed. Four years later he returned to the Iberian Peninsula and was baptized, later serving as a foot-soldier in Navarre until at least 1609 and in the Armada of the Ocean Sea: Tarruell, "Circulations," 210. Miguel Joseph de Austria and Jacinto de Austria were baptized in 1703 and 1707 respectively in the church of San Miguel in Larraga (Navarre): Alonso Acero, Sultanes, 162.

270 For the sixteenth century see Lobo Cabrera, "Rescates canarios." In 1765 two North African women were baptized in Las Palmas de Gran Canaria: Marrero, "Solemne bautizo de dos moras."

271 Muslims who had been baptized and met problems with the Inquisition were Margarita (1607), María or Fatima (1610), Francisco de la Cruz, a North African (1614), Miguel Tur, a North African (1614), Guillermo, a North African (1614), Jerónimo, a Turk (1617), María, of Moorish heritage (1623), Isabel Pastor and Jerónimo Pastor, both from Barbary (1629), Juan Bautista from Oran (1686), and Juan José Cayetano, a North African (1788). Many Moriscos faced the same fate: Vaquer Bennassar, Captius i renegats, 127-251. Between 1579 and 1689 thirty "Moors" were tried by the Inquisition: González-Raymond, La croix et le croissant, 282.

272 Diego López de Franca, a Moroccan from Tetouan, converted to Catholicism in 16oo. In 1604 the Council of War granted fifty ducats to a convert of Ottoman origin who was in Sicily: Tarruell, "Circulations," 66, 153. Between 1685 and 1687 the list of galley slaves in Toulon notes the arrival of a forty-two-year-old black Moroccan who had converted in Spain: Boyer, "La chiourme," 73. 
Even such distant cities as Palencia received North Africans for baptism. The abbot of Husillos, at some time before 1597, welcomed several who came to him either willingly or by order of the king:

Even infidels from Barbary were well received and lodged in this house; the King sent many for him to catechize and baptize; others came of their own will, drawn by word of this generosity. He took them all in with great pleasure and some remained in the house after their baptism, with a salary and maintenance for the rest of their lives. ${ }^{273}$

Those Muslims may have been members of the retinues of rulers exiled to Spain, since as we saw above the authorities tried to distance them from North Africa by sending them north to Navarre, Old Castile, and Galicia.

The number of converts seems to have been considerable. Although it is difficult to present data from all the cases mentioned above, we can offer some of the most notable ones as proof that the issue deserves exhaustive monographic treatment:

TABLE 3 Converted Muslims

\begin{tabular}{llr}
\hline City/Region & Date & $\begin{array}{r}\text { Muslims } \\
\text { baptized }\end{array}$ \\
\hline Oran & $1563^{-1569}$ & 3,300 \\
Jaén & Sixteenth century & 285 \\
Málaga & 1581 & 135 \\
Córdoba & $1593-1598$ & 6 \\
Granada & Sixteenth-seventeenth centuries & 296 \\
Extremadura & Sixteenth-seventeenth centuries & 16 \\
Madrid & $1609-1700$ & 394 \\
Murcia & $1611-1632$ & 58 \\
Seville & 1672 & 44 \\
Barcelona & 1680 & 7 \\
Cartagena & $1679-1695$ & 11 \\
Cádiz & $1600-1799$ & 1,920
\end{tabular}

273 "Hasta con infieles venidos de Berberia fueron en esta casa muy bien recibidos y hospedados; muchos le envió el Rey para que los catequizase y bautizase; otros vinieron de su voluntad, que los traía la fama de esta liberalidad; a todos los acogía con mucho gusto, y algunos después de bautizados, perseveraron en casa, dándoles salario y ración para toda 
TABLE 3 Converted Muslims (cont.)

\begin{tabular}{lll}
\hline City/Region Date $\quad$ Muslims \\
baptized
\end{tabular}

$\begin{array}{llr}\text { Oran } & 175^{-}-1753 & 184 \\ \text { Málaga } & 175^{\circ}-1753 & 9 \\ \text { Majorca } & \text { Sixteenth-eighteenth centuries } & 30 \\ \text { TOTAL } & & 6,695\end{array}$

THE SOURCES ARE THOSE CITED THROUGHOUT THIS SECTION

The total should be considered a mere starting point, since it does not even include all the numbers cited in this section. I believe that the phenomenon has much greater significance than has been accorded it before now. It is clear that many converts took the step as a way of entering the Iberian Peninsula, and many others as a way of avoiding a future in slavery. ${ }^{274} \mathrm{~A}$ separate issue is the extent to which baptism integrated these neophytes fully into the Catholic Church, or how many of them returned to their former faith. We have seen how a number were sincere enough to have requested interment in churches and monasteries. We should bear in mind that with the exception of a few prominent figures, most baptized Muslims who lived quietly in their new religion produced few documents and are hard to identify.

A good number, in contrast, chose to return to Islam. Hundreds of baptized Muslims were tried by the Inquisition, most of them Moriscos but North Africans and Turks as well. In Majorca thirty "Moors" were tried between 1579 and $1689 ;{ }^{275}$ in Murcia from 1611 to 1632 fifty-eight met the same fate, including twenty-seven natives of Oran; ${ }^{276}$ and there were similar cases in Granada, ${ }^{277}$ Extremadura, ${ }^{278}$ and Catalonia. ${ }^{279}$

la vida": Alfaro, Vida ejemplar, chap. 28. In the mid-sixteenth century Juan from Alexandria was baptized in Palencia, and in 1591 Antonio from Fez: Bennassar, L'homme espagnol, 90.

274 There are many documented cases about which we know few details. Diego López de Franca from Tetouan converted in 160o. In 1604 the Council of War granted fifty ducats to a converted Ottoman Turk who was living in Sicily: Tarruell, "Circulations," 23, 153.

275 González-Raymond, La croix et le croissant, 282; Vaquer Bennassar, Captius irenegats, 238-51.

276 Vincent, "Musulmanes y conversión," 78.

277 These were Moriscos and North Africans who mocked Christian symbols and performed Muslim rites: Martín Casares, La esclavitud, 427-28.

278 Three Moors were tried by the Inquisition in Guadalcanal, Llerena, and Cáceres: Periáñez Gómez, Negros, mulatos, 368-69.

279 Blázquez Miguel, La Inquisición en Cataluña, 148-50, 346. 
We have mentioned that some Muslims, both slaves and freedmen, resisted conversion strongly in the face of pressure by certain sectors of the Church and the religious orders, particularly the Jesuits. These efforts seem to have been most intense in the second half of the seventeenth century, a period when Muslims were arriving on the coasts of the Peninsula in large numbers. The following examples will illustrate this trend.

In the Murcia/Cartagena region around 1667 Muslims used to gather in the chapel of the monastery of San Ginés, a house of cloistered Franciscans, in La Jara, about fifteen kilometers from Cartagena. During three feast days around 25 August in honor of the local saint (whom they considered a descendant of Mohammed) as many as four hundred came together, according to the father superior. ${ }^{280}$ Muslims from Málaga used to honor Mohammed in a ruined castle about five kilometers outside the city. ${ }^{281}$ In Vélez-Málaga in 1669 the Jesuits tried to convert a Muslim leader who mounted a vigorous opposition, and in the same year in Marbella a Quranic expert said to have been educated in Fez managed to keep any Muslims from converting. ${ }^{282}$

Resistance to baptism was also reflected in the poor attendance at Jesuit missions in Madrid in 1669 , as we saw above. ${ }^{283}$ Sometimes the resistance turned violent: in Granada a Turk who had been baptized in the Alhambra in $165^{2}$ was murdered six months later, ${ }^{284}$ and in Barcelona a galley slave stabbed a Jesuit who was trying to convert him. ${ }^{285}$

In short, Muslims converted to Christianity in larger numbers than has previously been thought even though there was considerable resistance to baptism. The entire subject, however, is an area for further research.

\section{5 (Limited) Freedom of Worship for Muslims}

As we explained in the Introduction, members of other religions had a certain latitude in maintaining their practices, although they could do so in only limited social spaces. ${ }^{286}$ For this reason the phenomenon has often been overlooked, while attention has been focused on the Inquisition and its persecution

\footnotetext{
280 In 1641 Barbary corsairs landed there and sacked the monastery: Vincent, "Musulmanes y conversión," 81.

281 Vincent, "Musulmanes y conversión," 81.

282 Vincent, "Musulmanes," 84.

283 Vincent, "Musulmanes," 84.

284 Vincent, "Musulmanes," 77.

285 Vincent, "Les Jésuites," 529.

286 Amelang, Historias paralelas, 37.
} 
of crypto-Jews, crypto-Muslims, and heretics. Treaties signed with countries of different religions created a narrow opening of liberty for Protestants, members of reformed sects, and Muslims, at least to a slight extent. The presence on Spanish soil of Protestants and Muslims, especially when they died and were buried there, favored slightly more permissiveness in religious practice or at least a willingness to look the other way.

For Muslims in particular, free or enslaved, local authorities had to accept certain religious observances - usually private ones, though some venues were semipublic, as we shall see later on. In Castile, Aragon, and Navarre the Muslims were descended from the Mudejars who had decided to remain under Christian rule and were once allowed free practice of their religion, however limited. ${ }^{287}$ After 1492 the Muslims of Granada found themselves in the same situation, but little by little this privilege was eroded until those of Granada and Castile in 1502, those of Navarre in 1515-1516, and those of Aragon in 1526 were forced into baptism.

From that point onward, in theory, unconverted Muslims could not live in the Catholic Monarchy's domains. Still, we have seen how ambassadors, envoys, tradesmen, exiles, and others frequented Spanish cities and ports freely, thanks to treaties that their rulers had signed with Spain - a situation that continued until 1574, when Tunis fell under Ottoman rule. After that date many Muslims still arrived in Spain, while the large number of enslaved Muslims required a certain tolerance of their religious practices; without it, Christian slaves and captives in North Africa would have been forbidden their own religious rites, as we saw in Chapter 2. It was pure pragmatism that dictated acceptance of Muslim rituals. The two shores of the Mediterranean therefore shared a degree of tolerance, though it was much more limited in Europe than in Muslim lands.

Unfortunately we have almost no information about even this limited practice of Islam in Spain during the sixteenth and seventeenth centuries. By the end of the latter period, however, information about semipublic manifestations of Islam begins to appear. We recall how in 169o, when the Moroccan ambassador Muhammad b. Abd al-Wahhab al-Gassani arrived in Spain, Muslim men, women, and children acclaimed him in Cádiz, Córdoba, and Madrid in a public show of their faith. ${ }^{288}$ The phenomenon was most notable in Cartagena, a strategic port where a large number of Muslim slaves resided and practiced their religion with the limitations we have mentioned above.

One might think that the spontaneous demonstrations of faith that Muslims offered to al-Gassani were unique, and tolerated only because he was an

287 Echevarría Arsuaga, La minoría islámica.

288 García Mercadal, Viajes de extranjeros, 286-87, 292-93, 303; al-Gassani, El viaje del Visir, $111,21,42$. 
important ambassador; but in fact there was a building in Cartagena that was used as a mosque at least from the late 1600 . In 1695 the city's Inquisition tribunal received a letter from the "king of Algiers," who had been deeply offended by attacks on that mosque, an edifice purchased by Muslims "where they receive their sick and perform their ceremonies and prayers and bury their dead." A lamp had been broken and several tapestries burned, while worshippers were forbidden to enter the building. The Dey of Algiers threatened to retaliate against Christian slaves in his Regency by closing the hospital and church that served them. ${ }^{289}$

It is likely that the place of Muslim worship remained open, though it was moved later on. When construction began on Cartagena's shipyard in 1733 a larger number of slave laborers was needed for that project and for extending and improving the port and the city's fortifications. In that same year Fatma, a Muslim resident of the city, bought from Juana Navarrete a house in Santa Lucía, to the southeast of the so-called "Castle of the Moors"; it was purchased with money collected from galley slaves and served as a rest-house and hospital for them. By 1755 it was described as a mosque and hospital. It held one room lit by a lamp, with rush matting on the walls and floor; a chest held the shroud in which cadavers were wrapped and the coffin in which they were conveyed to the cemetery. In a second room a cistern provided water for the ritual washing of corpses. Both free Muslims and slaves contributed to its upkeep through a fee of four maravedis per month. Its caretaker lived in the building and acted as a muezzin, issuing the call to prayer from a window; the faithful entered after removing their shoes, and prayed "raising their voices aloud all together."290

In the same year, 1755 , Christian residents of the Calle Gimero below the Castle of the Moors asked Cartagena's town council to move the "hospital of the Moorish slaves" elsewhere. It is not clear if they wanted it closed completely, but a priest named Diego de la Encina led a mob that again destroyed the religious objects it contained. ${ }^{291}$

The mosque continued to function in spite of the attack. Its maintenance must have been a significant burden to the faithful: in 1765 the slaves asked the marine supply office to return the clothing of deceased Muslims so that they could sell it, using the profits to cover the costs of the mosque and the burials. That official decided to send the petition to the governor of the Council - who at that moment

\footnotetext{
289 Vincent, "Musulmanes y conversión," 80.

290 The house may have been purchased in 1730, not 1733; but eventually the one bought in those years was exchanged for another owned by Pedro Sánchez Corbalán, at the end of the Calle del Ángel: Barrio Gozalo, Esclavos y cautivos, 154-55.

291 Martínez Rizo, Fechas y fechos, 1:24-25, 25 o.
} 
was the bishop of Cartagena - informing him of the rites that were performed in the mosque, which in his opinion constituted a public scandal. The governor replied that he was aware of the mosque's existence but had taken no measures for fear of reprisals against Christian churches in North Africa. It is clear, in any event, that Christian neighbors complained. ${ }^{292}$

Muslim worship, whether public or semipublic, was a reality, and must have become more evident when the Moroccan ambassador Sidi Ahmed al-Gazzal arrived in Cartagena in 1766 with the aim of ransoming Muslim slaves. His memoir illustrates what we have been describing:

As we drew near the city and were only a short distance away a group of Muslim men, women, and children came out to meet us in great excitement, repeating the word "Salvation!" and saying, "May God assist the son of my Lord, the Prophet of God, my Lord Muhammad ibn Abdallah!". We greeted and welcomed them and took an interest in their situation.They were people who had been freed but might as well have been still captive, for they could not leave the country, except those who were authorized by the Christians, if they were not in the king's service. ... We managed to calm them and promised them help from our ruler (may God aid him!), and we told them that they would attain what they asked, and that we would take them to the land of Islam if God wished it so. ${ }^{293}$

The Treaty of Peace, Friendship, and Commerce that Spain and Morocco signed in 1767 doubtless increased the degree of tolerance toward Muslim practices, but it makes no mention of religious freedom for Moroccans even in the private sphere. Since Spaniards in Morocco enjoyed total religious liberty, however, reciprocity was implicit in the treaty. In 1799 the two nations signed another Treaty of Peace, whose Article 12 read as follows: "Likewise Moroccans living in Spain may practice in private the acts proper to their religion, as they

292 Barrio Gozalo, Esclavos y cautivos, 154-55.

293 "Cuando nos acercábamos a esa ciudad, de la que sólo nos separaba una distancia, salió a nuestro encuentro un grupo de musumanes - hombres, mujeres y niños - que con gran alboroto proclamaban la palabra "salvación" para después seguir diciendo - ¡Que Dios ayude al hijo de mi señor, el Profeta de Dios, mi señor Muhammad ibn Abdallah! --. Los saludamos y les dimos la bienvenida interesándonos por su situación. Eran personas liberadas, pero su régimen era el del cautivo pues no podían salir del país, salvo aquellos a los que los cristianos se lo autorizaban y no estaban al servicio del rey. ... Procuramos calmarles, les prometimos ayuda por parte de nuestro señor - ¡Que Dios le ayude! - y les anunciamos que conseguirían aquello que pedían y que los llevaríamos a la tierra del Islam si Dios así lo deseaba": Paradela Alonso, El otro laberinto, 67. 
have done up to now." A comparison of the Spanish and Arabic texts of the treaty would establish if there are differences between them, but the Moroccans' obvious intent was to demand for their coreligionists in Spain the same freedom that Spaniards enjoyed in Morocco. ${ }^{294}$ Ever since the Middle Ages Muslims had been more tolerant than Christians in these matters.

Public manifestations of Islam produced reactions against it. In 1769 the Council of the Inquisition told the monarch that such a situation could not be permitted in Spain, "which, being proud of the purity and unity of its religion above all things, now contains a space for this abomination." It accused the Council's governor of cowardice and insisted that the laws of 1502 and 1712 be applied, expelling free Muslims and closing mosques. In April 1770 the king accepted the petition and issued a royal decree:

The Council of the Inquisition having shown the king the grave harms that arise from the presence in these kingdoms of free Moors or cortados, in violation of several laws and proclamations that order them not to reside in them, and from the presence of a mosque in Cartagena ... Because what the Council of the Inquisition requests in its petition is founded in royal laws and in accord with His Majesty's Catholicism, he has resolved that the aforesaid Mosque of Cartagena be extinguished and destroyed entirely, and that all the cortados or free Moors who live in that city or in any other part of these dominons be expelled. ${ }^{295}$

The Cartagena mosque was demolished in 1770 with the excuse of strengthening the fortifications in that part of the city. Measures were taken to ensure that slaves did not inform Maghrebi authorities, which might result in reprisals against Christians in Algiers and Tunis in the form of closing or razing their churches. The value of the building was assessed at 6,223 reales de vellón, a sum meant to be given to the slaves; but they refused it, insisting that another mosque be built equal to the first. As a concession they were ceded a space in the hospital where they could perform their funeral rites: "A hidden

294 Cantillo, Tratados, 685-91, quotation at 687.

295 "El Consejo de Inquisición ha hecho presente al Rey los graves prejuicios que se originan de existir en estos reinos los moros cortados o libres, contra varias leyes y pragmáticas que mandan que no se los permita residir en ellos, y la de existir en Cartagena una Mezquita... Siendo lo que pide el Consejo de Inquisicion en su consulta tan fundado en leyes reales, como conforme al catolicismo de S.M. ha resuelto se extinga y destruya enteramente la referida Mezquita de Cartagena y se ejecute la expulsión de todos los moros cortados o libres que existan en aquella ciudad o en cualquier otra parte de estos dominios": Barrio Gozalo, Esclavos y cautivos, 155 . 
place and very well suited for no one to impede them." The Muslims continued to complain, alleging that "they have no place to revere and wash their dead, that they give them no land [for burials], and that they throw them [the dead] into the sea." The military governor of Cartagena, Carlos Reggio, rejected their complaints in view of the space they had been given in the hospital. Again the Muslims retorted that the place was very small and open to the sky, and in addition was right next to the ward where patients in the last stages of syphilis were treated. ${ }^{296}$

In 1774 the director of the Christian hospital in Algiers informed the president of the Council that the laments of Cartagena's slaves had reached the ears of his Dey, who threatened to destroy the Christians' hospital and church and punish both slaves and priests unless another mosque was built for the Muslims of Cartagena. Spain took the threat seriously: just a few weeks later the king, with the Inquisitor General's approval, approved a new building meant for funerals, but "forbidding in it those abominable rites and ceremonies with which they created a scandal before, causing grave harm." The muezzin could not call to prayer and could enter the building only when a Muslim had died. Moreover it was not to be called a mosque, and that term could not appear in any document. The new edifice was built in the Santa Lucía neighborhood near the Muslim burying-ground at El Cabezo de los Moros. Construction began in May 1774 and cost 7,362 reales de vellón (including the 6,223 from the razing of the previous building four years earlier), and resulted in a structure "without windows to the outside, only into a courtyard" and without access to the roof. The slaves accepted the new conditions and raised no more complaints. ${ }^{297}$

We should note here that Spanish authorities allowed Muslims who testified in legal matters to swear "in accordance with their sect." This practice is documented in Valencia in the sixteenth century: Amet signed in Ottoman script while another slave "swore facing the qibla, by Mohammed."298

In concluding this section we will mention briefly the burial places and rites devoted to dead Muslims, whether free or enslaved. It has been believed that no special areas were set aside for burials of members of other religions or non-Catholic Christian sects (the first official non-Catholic cemetery in Spain was opened in Málaga in 1831). But Muslims and Protestants who died in Spain had to be buried - though along the coasts it was not uncommon to toss their corpses into the sea.

296 Barrio Gozalo, Esclavos y cautivos, 155-56, 181-82.

297 Barrio Gozalo, Esclavos y cautivos, 181-82; Martinez Rizo, Fechas y fechos, 1:220.

298 Pomara Saverino, "Esclavos, identificación," 235. 
Nonetheless pragmatism played a role here too, based on maintaining reciprocity between different sovereigns and countries. Muslims were permitted burials in their own cemeteries at least until 1526, when those of Aragon were forcibly converted; at that point their cemeteries were confiscated and closed, though the history of the process requires further study. Muslim corsairs who died fighting on land or near the coast, or drowned, were buried on beaches, but there was still no solution for slaves or free Muslims who were either passing through Spanish domains or residing there. We have no data for the sixteenth and seventeenth centuries, but in the eighteenth, as we saw in the previous section, there was an area set apart for the purpose in Cartagena. Like the mosque, it was acquired with donations from slaves working on the shipyard and was located in El Cabezo de los Moros, not far from the mosque. ${ }^{299}$

Burials sometimes gave rise to incidents, of which we will mention some here though we have no sense of their frequency. In 1761 five slaves who had tried to escape complained to the Dey of Algiers: the plot they used as a cemetery had been taken from them and they were forced to bury their dead in corrals, as if they were horses - besides, people would throw stones at them during their funerals. When Algiers protested and the Secretary of the Navy ordered the supplier of Cartagena to investigate, he returned a declaration by twenty-five North Africans and Turks that denied the story. One of them, a corsair from Algiers named Omar, explained that although part of their previous plot had been taken away they had been compensated with a better one. He did acknowledge, however, that a boy had once thrown a stone at a funeral procession.

Attacks on funerals must have been fairly common, because in 1761 a sheriff and six soldiers were detailed to keep boys from Santa Lucía from mocking Muslims and throwing stones at them. When new complaints arose in 1770 the military governor, Carlos Reggio, admitted that there had been abuses but claimed they had ceased after the mosque was moved. According to him, burials proceeded normally in El Cabezo de los Moros:

They do not suffer the mockery from boys that they used to be exposed to, when as they were bringing the corpse into town many [boys] would gather and follow them out of mere curiosity; that has later been avoided by placing the hospital outside the city walls and carrying the corpses

299 Barrio Gozalo, Esclavos y cautivos, 181-82. 
from it to El Cabezo, where no one notices because [it has become] a long-established custom..$^{300}$

This topic, on which more research is also needed, does not end here: as we shall see in Chapter 8, complaints by Moroccans would again cause deep concern to Spanish rulers.

\subsection{Diplomacy with the Maghreb in Castilian Spanish}

The flow of peoples between the Maghreb and Spain favored a great increase in the number of North Africans who were fluent in Spanish, including some who could write it as well. First there were the Muslims who, already knowing the language to some degree, chose to move to North Africa when their regions were taken in the Christian Reconquest. Sephardic Jews who settled in the Maghreb after their own expulsion also retained their Spanish language, ${ }^{301}$ as did the expelled Moriscos who went to Morocco and Tunis. ${ }^{302}$ Then there were the Maghrebis who learned Spanish while living in Spain for long periods as slaves, merchants, and adventurers. Renegades, who were especially numerous in the Regencies and Morocco, and the smaller number of Spanish Christian slaves contributed to the use of Spanish in many areas of daily life: at North African courts, at sea in general, and in corsair warfare in particular. ${ }^{303}$

Some of those who left Spain for the various reasons described above placed their talents at the service of the sultans of Morocco. Many were Jews who decided to settle in Morocco and other North African lands after their expulsion in 1492. Those who had been scribes or officials at the Spanish court and had relevant experience and skills in administration, accounting, and commercial and diplomatic relations offered them in their new home; this was

300 "Sin sufrir las burlas de los muchachos a que antes estaban más expuestos, porque trayendo el cadáver a la población se juntaban muchos y los seguían, aunque fuese solo por curiosidad, lo que se ha evitado después por la situación del hospital extramuros de la ciudad, conduciendo los cadáveres desde él al expresado cabezo, en que ya nadie repara por la envejecida costumbre": Barrio Gozalo, Esclavos, 157, 178-82.

301 There is much attention to this issue in García-Arenal, Entre Islam y Occidente; Fierro, Judíos en tierras de Islam, vol. 1; Alcalá, Judíos, sefardíes.

302 Benítez Sánchez-Blanco, "Éxodo"; Epalza, El español hablado en Túnez; Epalza and Petit, Recueil d'études sur les moriscos; Oliver Asín, "Un morisco de Túnez."

303 Maziane, "Le castillan, langue de la marine." 
one of the factors that made of Spanish in the sixteenth and seventeenth centuries the required language for diplomatic communication with this country [Morocco]. This practice is reinforced by the presence of a large number of captives, merchants, and somewhat later, Moriscos. ${ }^{304}$

Spanish was therefore in use at the Moroccan court and in the governments of several cities such as Tetouan and Rabat; at least, there were persons who were fluent and could be called on to compose letters in that language. ${ }^{305}$ We have abundant documentary evidence of the role that Spanish played in diplomatic relations between Europe and the Maghreb, particularly Morocco, in the sixteenth and seventeenth centuries.

A correspondence was established between the Moroccan chancellery and the Duke of Medina Sidonia, who from his seat in Sanlúcar de Barrameda was responsible for communication with Morocco from the mid-15oos well into the following century. Interpreters at the Moroccan court wrote many letters directly in Spanish, after which the sultan simply appended his signature. Sometimes a letter written in Arabic would arrive together with its translation into Spanish. In 1605 the Duke of Medina Sidonia informed King Philip III:

Alonso Marín has just arrived from Morocco by way of Safy, in an English ship of the line ... and through him the Sharif Muley Biferes replies to the original letter that accompanies this one, and there was a translation along with it, which is something new among these Sharifs in the correspondence I have had with them. ${ }^{306}$

Moriscos who had captured the fortress of Rabat, and who corresponded with Spanish authorities about the possibility of exchanging it for their right to return to Spanish soil, wrote some of their letters in Spanish. ${ }^{307}$

304 “...[U]no de los factores que hacen que el castellano se convirtiera durante los siglos XVI y XVII en la lengua obligada para la comunicación diplomática con este país. Este uso viene reforzado por la existencia de un gran número de cautivos, de mercaderes, y algo más tarde, de moriscos": García-Arenal et al., Cartas marruecas, 9-10, 19-20.

305 A large proportion of the letters sent from Morocco in the sixteenth and seventeenth centuries and held in the Archivo General de Simancas were written in Spanish, with one or two additional lines of certification and validation in Arabic: García-Arenal et al., Cartas, 9-10.

306 "Acava de llegar Alonso Marin de Marruecos por la vía de Safy en un navío inglés ... y con él me responde el xerife Muley Biferes la carta original ques con ésta y dentro della benia traducida, cossa nueva y no usada entre estos xerifes por la correspondencia que yo he tenido con ellos": García-Arenal et al., Cartas, 17.

García-Arenal et al., Cartas, 142-46; Colin, "Projet de traité." 
In Morocco's diplomatic relations with France, England, and the United Provinces of the Netherlands the practice of writing in Spanish was not unknown. In correspondence between the French King Louis XIII and the fortress of Sale there are several letters in that language. ${ }^{308}$ The same happened in Anglo-Moroccan relations. In 1621 the governor of Tetouan wrote in Spanish to Walter Aston, who had been ambassador to Spain: "Juan Duppa, an English gentleman, has arrived here to negotiate the ransom of Andalusians captured by the fleet of the king of Great Britain; and by order of his general he can perform only an exchange of one man for one man." ${ }^{309}$ The treaty signed by Great Britain and Morocco in 1638 was translated into Spanish. ${ }^{310}$ The Dutch received several letters in that language from the governors of Rabat, including one to the Prince of Orange in 1629 and one to the Estates General in $1635^{311}$

Up to a late date there were comments on the extent to which Spanish was used in Morocco. In 1683 Germain Mouëtte, who was a captive there for eleven years, wrote that "The Moors [i.e., Moriscos], on moving there [to Morocco], took the Spanish language which still today is as common as Arabic." 312

Among corsairs, many ships' captains and crew members either spoke Spanish fluently or understood it readily. Marie Ter Meteleen spent twelve years in captivity in Morocco after the ship in which she was sailing was captured in 1731: the corsairs had "immediately sent their captain aboard, and I welcomed him with a grand compliment in Spanish that he understood well, as did a few of his men."313

There is no doubt that Spanish was common in the seafaring environment in general and among corsairs in particular. In around 1781 the Danish consul, Georges Höst, noted how many Spanish words there were in sailors' vocabulary. Almost a century and a half later, in 1920, a study of terms related to the sea in Rabat-Salé concluded that sixty percent were Arabic and thirty percent Spanish, with the remaining ten percent distributed among Italian, French, Turkish, and Berber (Amazigh). ${ }^{314}$

\footnotetext{
308 Maziane, "Le castillan," 204-05.

309 Sources inédites de l'Histoire du Maroc, Series 1, Angleterre, vol. 2, 21 December 1621; vol. 3, March 1626-166o, 16-20. See Maziane, "Le castillan," 205.

310 García-Arenal et al., Cartas, 45.

311 Maziane, "Le castillan," 205-06.

312 "Les Maures en s'y retirant, y portèrent la langue espagnole qui est encore aussi commune aujourd'hui que l'arabe": Maziane, “Le castillan," 206.

313 "[I]nmédiatament ils mirent le capitaine [corsaire] à notre bord, à qui je souhaitai la bienvenue avec un grand compliment en espagnol qu'il savait bien comprendre ainsi que quelques uns de ses hommes": Maziane, "Le castillan," 206-07.

314 Maziane, "Le castillan," 207-08; Levy, "Ports parlers portuaires."
} 
It is even more important to recall that prominent members of the Moroccan court understood Spanish. One was Muhammad Ibn Utman, the ambassador to Spain in 1780 and 1791-1792. He needed no interpreter in his first interview with the Secretary of State, Floridablanca, "although he prefers not to speak it in public because he thinks he speaks it ill, and perfers the help of interpreters." ${ }^{315}$ Nonetheless, before Ibn Utman's first embassy to Spain he requested in Ceuta to be accompanied by the local interpreter; the governor denied him, claiming that "he does not need him because his own makes himself very well understood in Spanish."316

Other Moroccans knew at least some Spanish: one was Muhammad alDalimi, who traveled to Cádiz in May 1792 as the ambassador from Muley Hisam, who was contesting the throne with his brother Muley al-Yazid. His interpreter on that occasion was Pedro Umbert, the former secretary to $\mathrm{Mu}-$ hammad Ben Abdallah. ${ }^{317}$

When the Polish author Jean Potocki visited Tetouan in July 1791, he found himself at a gathering without his interpreter but in which "several persons present spoke Spanish." ${ }^{318}$ The abovementioned secretary Pedro Umbert was a Spanish former slave. ${ }^{319}$

As we have shown in the preceding pages, a large number of Muslims (ambassadors and envoys, merchants, freedmen baptized or unbaptized, travelers, and adventurers) lived temporarily or permanently on Spanish soil from the sixteenth century to the first half of the eighteenth.

This fact coexists with, and contradicts, the hostility that reigned between the Hispanic Monarchy and Muslim rulers in the Mediterranean and reduced hundreds of thousands of persons to slavery or captivity. Policies of reciprocity, therefore, should be seen as strategic rather than erratic. One proof is the large number of embassies sent from Muslim lands to Spain - not as many as to Venice and France, but more than were sent to other European countries. Even now we do not know just how many reached Spanish dominions. The

315 Rodríguez Casado, La política, 289, 304.

316 Domingo de Salzedo, military governor of Ceuta, to Count Floridablanca, Ceuta, 13 November 1779: AHN, Estado, Leg. 5819 .

317 Arribas Palau, "Embajadas marroquíes" and "Nuevos datos sobre la embajada."

318 He also reports that in the card game of tresillo or ombre, popular throughout Morocco, the vocabulary was Spanish: Potocki, Viaje al Imperio de Marruecos, 36, 44.

319 Umbert accompanied Ibn Utman's embassy to the Spanish court: Rodríguez Casado, $\mathrm{La}$ política, 295-96, 317. 
number of Muslim tradesmen does not seem to have varied much from country to country; Venice seems to have received the most, but Spain and its Italian domains were not far behind.

Spanish society was divided over whether to expel free and enslaved Muslims, either altogether or from coastal areas - as it was in the case of the Moriscos. While some saw them as a threat, for others they were essential to local economies. Everthing suggests that slave owners resisted all efforts to expel such a cheap and abundant source of labor. They also limited the scope of expulsions, since the monarchy was content to send many Muslims, especially freedmen, to cities in the center and north of the Peninsula.

The number of Muslims who were free, freedmen, merchants, and adventurers who chose Spain for many reasons was demonstrably larger than the number who went to more northerly European countries, France included. In no other country did as many Muslims convert to Christianity, whether out of conviction or self-interest - not even in Spain's Italian domains or in Rome, the capital of Christendom. No free Muslims lived in any other European country in such numbers. More North African immigrants, especially Moroccans and Algerians in the terrible years of 1521-1522, 1609-1611, and 1750-1751, went to Spain than to any other country in Europe. ${ }^{320}$ The same could be said of travelers and adventurers. Spain was the country that harbored the largest number of Muslims, either for brief periods or for life.

The number of Muslims who were manumitted on Spanish soil was also dominant. While freedmen in Spain were a tiny minority compared to Muslim slaves, who were vastly outnumbered in turn by sub-Saharan Africans, there were many more of them than in other European countries.

In the light of all this it makes little sense to apply the notion of the "forgotten frontier" almost exclusively to the Spanish case. B. Vincent is more accurate in his view of a porous, much-crossed boundary:

On the one hand [there were] Muslim communities spread all over Spanish territory and tolerated by the authorities; on the other, extreme caution and an unceasing effort to convert their members. These two constellations, far from being contradictory, demonstrate the persistent vigor of the frontier between Islam and Christendom in seventeenth-century

320 B. Vincent has called attention to this phenomenon, noting that the number of Moriscos who either remained in Spain or returned there has overshadowed the migration of North Africans who came to Spain because of economic circumstances at home in the sixteenth and seventeenth centuries, or in corsair activity. Their arrival helped to bolster the Moriscos' Islamic faith, which had been deteriorating: "Musulmanes y conversión," 78. 
Spanish consciousness. One always had to count on the presence of Turks and North Africans, powers with which there was daily contact in the Mediterranean, North Africa, and even the interior of the Iberian Peninsula. Many people passed from one world to another in either direction, and if [a country] did not wish to lose its own it had to accept the others. This modus vivendi existed while [Spain] hoped for a decisive victory over the most feared enemy of Mediterranean Christendom. There are two ways to triumph: by way of arms or by way of souls. ${ }^{321}$

Though more research is needed, everything indicates that the thousands of Muslims on Spanish soil - like the thousands of Christians in Muslim lands maintained relations with their countries of origin, helping to weave ties and networks between the two opposing worlds.

All the events described above contributed to the image that each side forged of the other - both "the other" from across the sea and the one who lived in the same city or town. It was a frightening image, born of the accumulated stereotypes of centuries, but in the circumstances we describe the "image" contained elements of nearness and realism; the Muslim Other involved real people and behaviors that were familiar from daily life. That nearness and realism overlapped with the hostility and drive to dominate that ruled both societies, so that the inhabitants of the two Mediterranean shores did not see themselves as so different after all.

In Spain as in the other Western European countries, Muslim ambassadors with their retinues and exotic animals, as well as captured corsair captains, aroused enormous curiosity in society at large. The sentiment was encouraged in part by the authorities themselves, who ordered towns on the ambassadors' itineraries to offer them a warm welcome.

321 "Por un lado, unas comunidades musulmanas dispersadas por el territorio español y toleradas por la autoridad; por otro, un cuidado extremo, un esfuerzo infatigable para convertir a sus miembros. Lejos de ser contadictorias estas dos constelaciones traducen el vigor persistente de la frontera entre islam y cristiandad en las conciencias españolas del siglo XVII. Turcos y berberiscos constituyen siempre unos poderes con los cuales es preciso contar, poderes con los cuales el contacto es cotidiano en el Mediterráneo, en África del Norte, e incluso en el interior de la península ibérica. Muchos hombres pasan en los dos sentidos de un mundo a otro. Y si no se quiere perder a los suyos, es preciso aceptar a los otros. Es así un modus vivendi a la espera de la victoria decisiva sobre el que, para la cristiandad mediterránea, representa al enemigo temido por excelencia. Hay dos maneras de triunfar, por la vía de las armas y por la vía de las almas": Vincent, "Musulmanes y conversión," 86. 
The great majority of the Muslims who interest us here, however, were slaves or freedmen, baptized or not, who suffered the same privations as other sectors of Spanish society: day laborers, wage laborers, paupers, gypsies, condemned prisoners, and other marginalized groups. There must have been a certain harmony among them even while they competed for the scarce opportunities offered by a hierarchical society such as that of Spain in the Early Modern Age. 